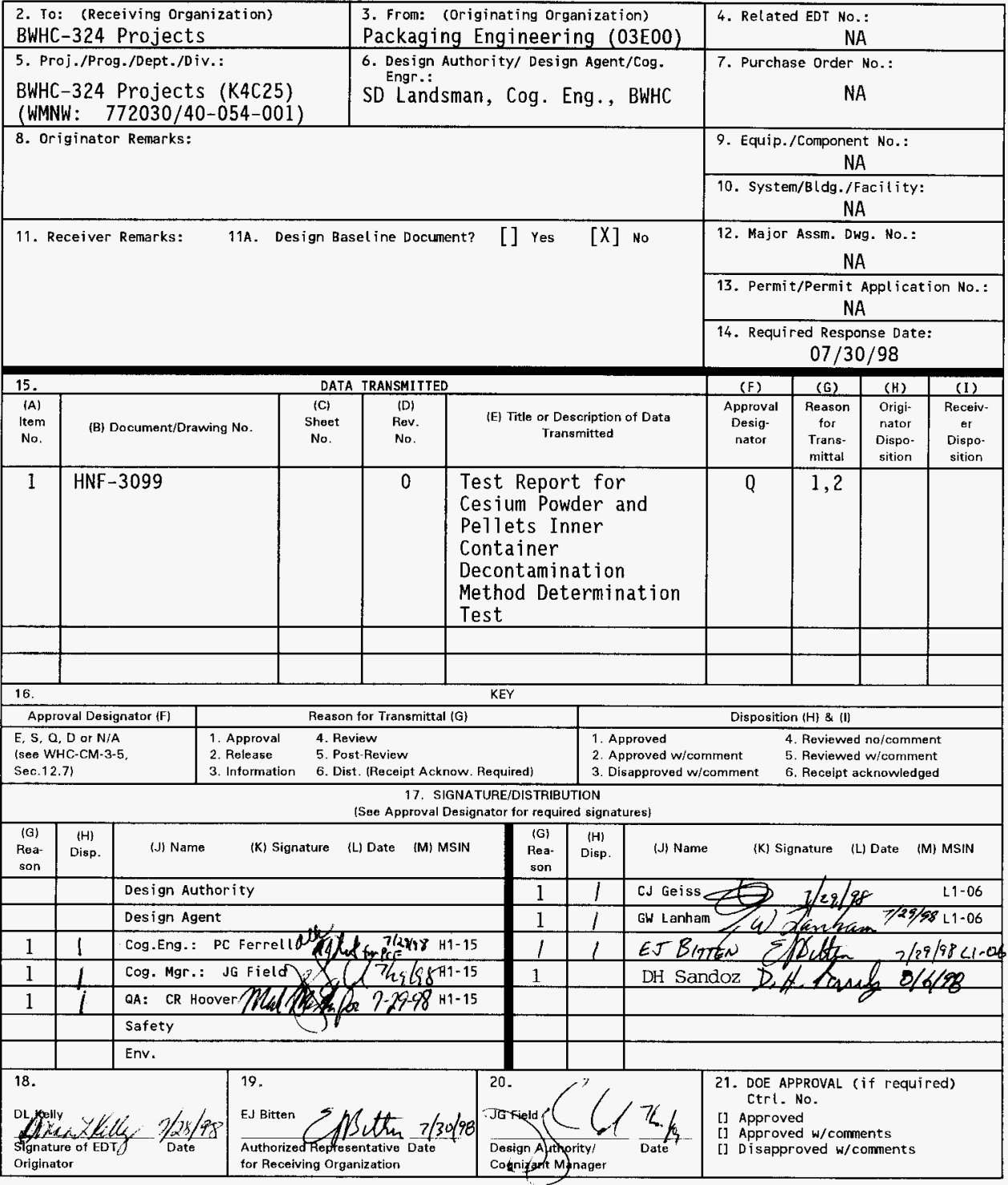


HNF-3099, Rev. 0

\section{TEST REPORT FOR CESIUM POWDER AND PELLETS INNER CONTAINER DECONTAMINATION METHOD DETERMINATION TEST}

D. L. Kelly

Waste Management Federal Services, Inc., Northwest Operations Richland, WA 99352

U.S. Department of Energy Contract DE-AC06-96RL13200

$\begin{array}{lll}\text { EDT/ECN: } & 622929 & \text { UC: } 513, u C-2000 \\ \text { Org Code: } 03 \text { E00 } & \text { Charge Code: K4C25 } & (772030 / 40-054-001) \\ \text { B\&R Code: } & \text { EW7050000 } & \text { Total Pages: } \mathbf{7 9} \mathrm{cw} 8-17-98\end{array}$

Key Words: Cesium Powder and Pellets, Inner Container, Decontamination.

Abstract: Three Cesium Powder and Pellets Inner Containers underwent performance testing in July 1998. A total of thirteen tests were conducted. The test plan (HNF-2945) was revised extensively in the field during testing. As a result, this Test Report contains the official test documentation and provides a single document reference. The "Heat/Scrub Test Using Water Dampended Rags (Modification 1)" was successful in that there were three passes.

TRADEMARK DISCLAIMER. Reference herein to any specific comercial product, process, or service by trade name, trademark, manufacturer, or otherwise, does not necessar ily constitute or imply its endorsement, recommendation, or favoring by the United States Government or any agency thereof or $i$ ts contractors or subcontractors.

Printed in the United States of America. To obtain copies of this document, contact: Document Control Services, P.O. Box 950, Mailst op H6-08, Richland WA 99352, Phone (509) 372-2420; Fax (509) 376-4989.
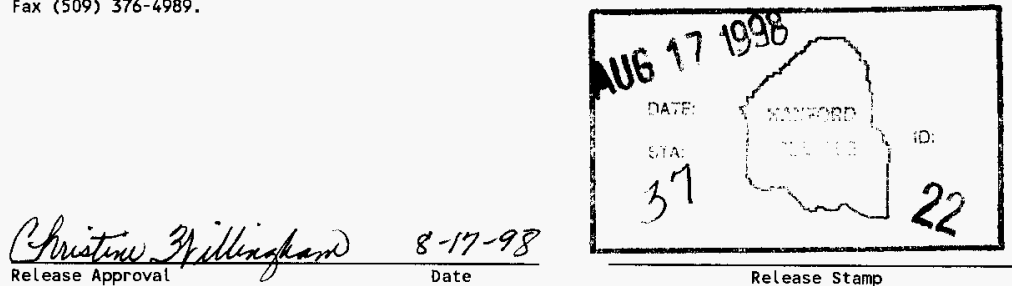

Release Stamp 
HNF-3099 Rev. 0

\section{CONTENTS}

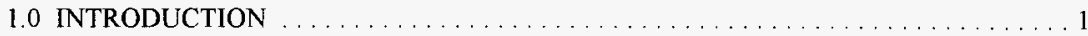

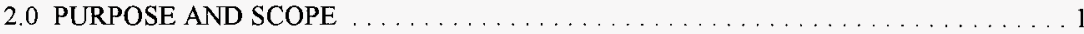

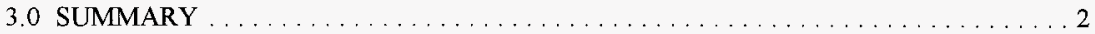

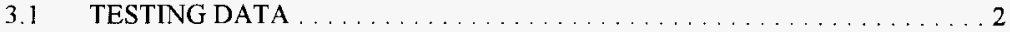

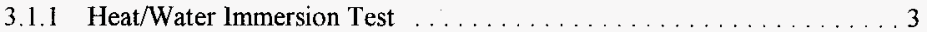

3.1.2 Heat/Water Spray Test (Modification 1) ................4 4

3.1 .3 Scrub Test Using Water Saturated Rags . . . . . . . . . . . . . . . 6

3.1 .4 Heat/Water Spray Test (Modification 2) $\ldots \ldots \ldots \ldots \ldots \ldots \ldots$

3.1 .5 Heat/Water Immersion Test (Modification 1) . . . . . . . . . . . . 9

3.1 .6 Heat/Water Spray Test (Modification 3) . . . . . . . . . . . . . . 12

3.1.7 Heat/Scrub Test Using Water Saturated Rags (Modification 1) . . . . . 13

3.1.8 Heat/Scrub Test Using Water Dampened Rags (Modification 1) . . . . 15

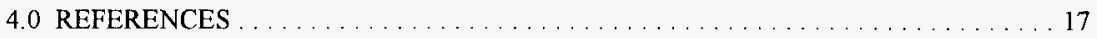

APPENDIX A TEST PLAN - FIELD COPY DOCUMENTATION $\ldots \ldots \ldots \ldots \ldots$ A-l

\section{LIST OF TABLES}

Table 3-1. Tests Conducted. . . . . . . . . . . . . . . . . . . . . 2

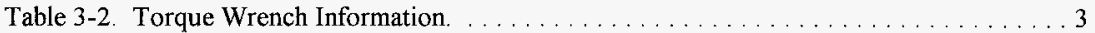

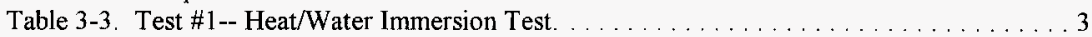

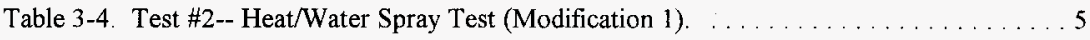

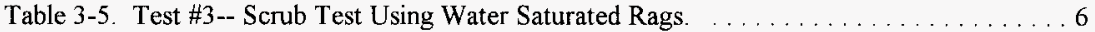

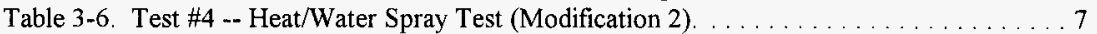

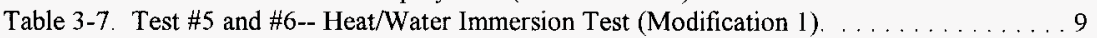

Table 3-8. Test \#7 -- Heat/Water Spray Test (Modification 3) $\ldots \ldots \ldots \ldots \ldots \ldots \ldots$

Table 3-9. Test \#8, \#9, and \#10 --

Heat/Scrub Test Using Water Saturated Rags (Modification 1). . . . . . . . . 14

Table 3-10. Test \#11, \#12, and \#13 --

Heat/Scrub Test Using Water Dampened Rags (Modification 1). . . . . . . . 16 
HNF-3099 Rev. 0

\section{LIST OF TERMS}

$\begin{array}{ll}\text { BWHC } & \text { B\&W Hanford Company } \\ \text { NHC } & \text { Numatec Hanford Company } \\ \text { QA } & \text { Quality Assurance } \\ \text { WMNW } & \text { Waste Management Federal Services, Northwest Operations }\end{array}$ 
HNF-3099 Rev. 0

\section{TEST REPORT FOR CESIUM POWDER AND PELLETS INNER CONTAINER DECONTAMINATION METHOD DETERMINATION TEST}

\subsection{INTRODUCTION}

This report documents the decontamination method determination testing that was performed on three cesium powder and pellets inner container test specimens. The test specimens were provided by B\&W Hanford Company (BWHC). The tests were conducted by the Numatec Hanford Company (NHC), in the 305 Building. Photographic evidence was also provided by NHC. The Test Plan and Test Report were provided by Waste Management Federal Services, Inc., Northwest Operations (WMNW). Witnesses to testing included a WMNW test engineer, a BWHC project engineer, and a BWHC Quality Assurance (QA) representative.

The Test Plan was modified with the mutual decision of the WMNW test engineer, the BWHC project engineer, and the BWHC QA representative. The results of this decision were written in red (permanent type) ink on the "official copy" of the test procedure. Due to the extent of the changes, a summary of the test results are provided in Section 3.0 of this Test Report. In addition, a copy of the "official copy" field documentation obtained during testing is included in Appendix A. The original Test Plan (HNF-2945) will be revised to indicate that extensive changes were required in the field during testing; however, the test documentation will stand as is (i.e., it will not be retyped, text shaded, etc.) due to the inclusion of the test parameters and results into this Test Report.

\subsection{PURPOSE AND SCOPE}

The Cesium Powder and Pellets Inner Container was performance tested per the criteria specified in Section 4.0 of HNF-2399, Design, Fabrication, and Assembly Criteria for Cesium Powder and Pellet Inner Container, and Task Order SW826. The test criteria specified that the Inner Container be water tight during decontamination of the exterior surface. Several different test methods were applied, as documented within the Test Plan and as provided in the Summary (Section 3.0) below. Any in-leakage of fluorescent water to the Inner Container constituted a container seal failure. 
HNF-3099 Rev. 0

\subsection{SUMMARY}

Thirteen tests were conducted using three test specimens (C-PP10, C-PP11, and C-PP12). Tabie 3-1 identifies the tests conducted, status, and the section location within this Test Report where information may be found. The Heat/Scrub Test Using Water Dampened Rags (Modification 1), that was conducted as Test \#11, \#12, and \#13, was successful in that there were three passes.

The pretest requirements described in Section 6.1 of the Test Plan, and the preparation of the test specimens described in Section 6.2 of the Test Plan were followed prior to conducting any of the tests described in this report. In addition, the lid and body interface for all test specimens was checked and polished prior to conducting any additional tests with that specimen.

Table 3-1. Tests Conducted.

\begin{tabular}{|c|c|l|c|}
\hline $\begin{array}{c}\text { Test } \\
\text { Number }\end{array}$ & $\begin{array}{c}\text { Test Report } \\
\text { Section }\end{array}$ & \multicolumn{1}{|c|}{ Test Type } & Status \\
\hline 1 & 3.1 .1 & Heat/Water Immersion Test & Fail (1) \\
\hline 2 & 3.1 .2 & Heat/Water Spray Test (Modification 1) & Fail (1) \\
\hline 3 & 3.1 .3 & Scrub Test Using Water Saturated Rags & Pass (1) \\
\hline 4 & 3.1 .4 & Heat/Water Spray Test (Modification 2) & Pass (1) \\
\hline $5 \& 6$ & 3.1 .5 & Heat/Water Immersion Test (Modification1) & Fail (2) \\
\hline 7 & 3.1 .6 & Heat/Water Spray Test (Modification 3) & Fail (1) \\
\hline $8,9, \& 10$ & 3.1 .7 & Heat/Scrub Test Using Water Saturated Rags (Modification 1) & Pass (1) \\
\hline $11,12, \& 13$ & 3.1 .8 & Feat/Scrub Test Using Water Dampencd Rags (Modification 1) & Pass (3) \\
\hline
\end{tabular}

\subsection{TESTING DATA}

Due to the extensive changes made during testing, the information in this section has been extracted from the Test Plan "official copy" that was used in the field, and is provided in Tables 3-2 through 3-10 for easy reference. The tables are identified by test number and test 
HNF-3099 Rev. 0

type. A copy of the "official copy" of the Test Plan that was used in the field during testing is provided as Appendix A to this report.

The temperature gauges and timing devices used during testing were not calibrated. All temperatures and times provided in this report are approximate.

The information for the torque wrench used during testing is provided in Table $3-2$. The same torque wrench was used for all tests.

Table 3-2. Torque Wrench Information.

\begin{tabular}{|l|l|}
\hline Torque Wrench Identification & $545-88-01-202$, serial number 6064 \\
\hline Next Calibration Due Date & $2 / 27 / 99$ \\
\hline Accuracy & $+/-4 \%$ \\
\hline
\end{tabular}

\subsubsection{Heat/Water Immersion Test}

The first test conducted was the Heat/Water Immersion Test as described in Section 6.3 of the Test Plan. This test was not modified in the field. The following information represents the data collected during testing:

Table 3-3. Test \#1-- Heat/Water Immersion Test.

\begin{tabular}{|l|l|l|l|}
\hline & \multicolumn{1}{|c|}{$\begin{array}{c}\text { Test Specimen: } \\
\text { C-PP10 }\end{array}$} & \multicolumn{1}{|c|}{$\begin{array}{c}\text { Test Specimen: } \\
\text { C-PP11 }\end{array}$} & \multicolumn{1}{|c|}{$\begin{array}{c}\text { Test Specimen: } \\
\text { C-PP12 }\end{array}$} \\
\hline Test Contents & Empty & N/A & N/A \\
\hline Seal Type & Polished & N/A & N/A \\
\hline $\begin{array}{l}\text { Heated Container } \\
\text { Temp (Oven) }\end{array}$ & $201.1^{\circ} \mathrm{C}\left(394^{\circ} \mathrm{F}\right)$ & N/A & N/A \\
\hline Initial Cap Torque & $25 \mathrm{ft}-\mathrm{lb}$ & N/A & N/A \\
\hline $\begin{array}{l}\text { Cooled Test } \\
\text { Specimen Temp. }\end{array}$ & $74.4^{\circ} \mathrm{C}\left(166^{\circ} \mathrm{F}\right)$ & N/A & N/A \\
\hline Verified Cap Torque & $25 \mathrm{ft}-\mathrm{lb}$ & N/A & N/A \\
\hline
\end{tabular}


HNF-3099 Rev. 0

Table 3-3. Test \#1-- Heat/Water Immersion Test.

\begin{tabular}{|c|c|c|c|}
\hline & $\begin{array}{l}\text { Test Specimen: } \\
\text { C-PP10 }\end{array}$ & $\begin{array}{l}\text { Test Specimen: } \\
\text { C-PP11 }\end{array}$ & $\begin{array}{l}\text { Test Specimen: } \\
\text { C-PP12 }\end{array}$ \\
\hline Retorque Required & Yes & $\mathrm{N} / \mathrm{A}$ & N/A \\
\hline Water Temp. & $29.4^{\circ} \mathrm{C}\left(85^{\circ} \mathrm{F}\right)$ & N/A & N/A \\
\hline Immersion Depth & $8 \mathrm{ft}, 8$ in. & $\mathrm{N} / \mathrm{A}$ & N/A \\
\hline Start Time & $11: 36: 16$ & $\mathrm{~N} / \mathrm{A}$ & N/A \\
\hline End Time & $11: 41: 28$ & $\mathrm{~N} / \mathrm{A}$ & N/A \\
\hline Breakaway Torque & $\begin{array}{l}\text { started @ 50, } \\
\text { broke@ } 28=22 \mathrm{ft}-\mathrm{lb}\end{array}$ & $\mathrm{N} / \mathrm{A}$ & N/A \\
\hline $\begin{array}{c}\text { Fluorescein/Moisture: } \\
\text { Seal } \\
\text { Gasket } \\
\text { Threads } \\
\text { Inside }\end{array}$ & $\begin{array}{l}\mathrm{Y} \\
\mathrm{Y} \\
\mathrm{Y} \\
\mathrm{Y}\end{array}$ & N/A & N/A \\
\hline $\begin{array}{l}\text { Galling: } \\
\text { Threads } \\
\text { Seal }\end{array}$ & $\begin{array}{l}\mathrm{N} \\
\mathrm{N}\end{array}$ & $\mathrm{N} / \mathrm{A}$ & N/A \\
\hline Result of Test & Fail & N/A & $\mathrm{N} / \mathrm{A}$ \\
\hline Comments & \multicolumn{3}{|c|}{$\begin{array}{l}\text { The gasket shifted over slightly upon the final torque. Upon opening } \\
\text { the test specimen, a drop of moisture was observed under the gasket. } \\
\text { Approximately } 90 \text { mil. of water and fluorescein was removed from the } \\
\text { test specimen after the test. }\end{array}$} \\
\hline
\end{tabular}

\subsubsection{Heat/Water Spray Test (Modification 1)}

The second test conducted consisted of a combination of tests documented in the Test Plan; however, it was not originally a part of the Test Plan. For documentation purposes, this will be termed the Heat/Water Spray Test (Modification 1).

The Heat/Water Spray Test (Modification 1) conducted during Test \#2 consisted of heating an empty test specimen to approximately $200^{\circ} \mathrm{C}\left(392^{\circ} \mathrm{F}\right)$, placing the closure cap onto the Container, letting the container be free-air cooled to approximately $100^{\circ} \mathrm{C}\left(212^{\circ} \mathrm{F}\right)$, and the 
closure cap torqued to $25 \mathrm{ft}-\mathrm{lb}$. The Container was then sprayed with a mixture of water and fluorescein that was delivered through a $3 / 8$-in. diameter tube from a container that was elevated $4 \mathrm{ft}$ above the container seal area. The water was sprayed onto the seal area of the Container for two periods of at least 2 minutes each. After the test the closure caps were removed, and the inside of the Container was examined for water. In addition, the threads and seals were inspected for galling. The following information represents the data collected during testing:

Table 3-4. Test \#2-- Heat/Water Spray Test (Modification 1).

\begin{tabular}{|c|c|c|c|}
\hline & $\begin{array}{l}\text { Test Specimen: } \\
\text { C-PP10 }\end{array}$ & $\begin{array}{l}\text { Test Specimen: } \\
\text { C-PP11 }\end{array}$ & $\begin{array}{l}\text { Test Specimen: } \\
\text { C-PP12 }\end{array}$ \\
\hline Test Contents & N/A & Empty & N/A \\
\hline Seal Type & N/A & Polished & N/A \\
\hline $\begin{array}{l}\text { Heated Container } \\
\text { Temp (Oven) }\end{array}$ & $\mathrm{N} / \mathrm{A}$ & $200^{\circ} \mathrm{C}\left(392^{\circ} \mathrm{F}\right)$ & $\mathrm{N} / \mathrm{A}$ \\
\hline Initial Cap Torque & N/A & $\mathrm{N} / \mathrm{A}$ & $\mathrm{N} / \mathrm{A}$ \\
\hline $\begin{array}{l}\text { Cooled Test } \\
\text { Specimen Temp. }\end{array}$ & N/A & $104.4^{\circ} \mathrm{C}\left(220^{\circ} \mathrm{F}\right)$ & $\mathrm{N} / \mathrm{A}$ \\
\hline Verified Cap Torque & $\mathrm{N} / \mathrm{A}$ & $25 \mathrm{ft}-1 \mathrm{~b}$ & $\mathrm{~N} / \mathrm{A}$ \\
\hline Retorque Required & N/A & N/A & N/A \\
\hline $\begin{array}{l}\text { Water Container } \\
\text { Height }\end{array}$ & $\mathrm{N} / \mathrm{A}$ & $4 \mathrm{ft}$ & N/A \\
\hline Period I Start Time & N/A & $2: 46: 18$ & $\mathrm{~N} / \mathrm{A}$ \\
\hline Period 1 End Time & N/A & 2:48:18 & $\mathrm{N} / \mathrm{A}$ \\
\hline Period 2 Start Time & N/A & $2: 48: 26$ & $\mathrm{~N} / \mathrm{A}$ \\
\hline Period 2 End Time & $\mathrm{N} / \mathrm{A}$ & $2: 50: 26$ & $\mathrm{~N} / \mathrm{A}$ \\
\hline Breakaway Torque & $\mathrm{N} / \mathrm{A}$ & $\begin{array}{l}\text { started @ 50, } \\
\text { broke @ } 30=20 \mathrm{ft}-\mathrm{lb}\end{array}$ & $\mathrm{N} / \mathrm{A}$ \\
\hline $\begin{array}{l}\text { Fluorescein/Moisture: } \\
\text { Seal } \\
\text { Gasket } \\
\text { Threads } \\
\text { Inside }\end{array}$ & $\mathrm{N} / \mathrm{A}$ & $\begin{array}{l}\mathrm{Y} \\
\mathrm{Y} \\
\mathrm{Y} \\
\mathrm{Y}\end{array}$ & $\mathrm{N} / \mathrm{A}$ \\
\hline
\end{tabular}


HNF-3099 Rev. 0

Table 3-4. Test \#2-- Heat/Water Spray Test (Modification 1).

\begin{tabular}{|l|l|l|l|}
\hline & \multicolumn{1}{|c|}{$\begin{array}{c}\text { Test Specimen: } \\
\text { C-PP10 }\end{array}$} & \multicolumn{1}{|c|}{$\begin{array}{c}\text { Test Specimen: } \\
\text { C-PP11 }\end{array}$} & $\begin{array}{c}\text { Test Specimen: } \\
\text { C-PP12 }\end{array}$ \\
\hline $\begin{array}{c}\text { Galling: } \\
\text { Threads } \\
\text { Seal }\end{array}$ & N/A & $\mathrm{N}$ & N/A \\
\hline Result of Test & N/A & Fail & N/A \\
\hline Comments & \multicolumn{2}{|c|}{ Approximately 1/2 teaspoon of water and fluorescein mixture was } \\
& observed inside the Container upon opening. \\
\hline
\end{tabular}

\subsubsection{Scrub Test Using Water Saturated Rags}

The third test was the Scrub Test Using Water Saturated Rags as described in Appendix B, Section B.3 of the Test Plan. This test was not modified in the field. The following information represents the data collected during testing:

Table 3-5. Test \#3-- Scrub Test Using Water Saturated Rags.

\begin{tabular}{|c|c|c|c|}
\hline & $\begin{array}{l}\text { Test Specimen: } \\
\text { C-PP10 }\end{array}$ & $\begin{array}{c}\text { Test Specimen: } \\
\text { C-PP11 }\end{array}$ & $\begin{array}{c}\text { Test Specimen: } \\
\text { C-PP12 }\end{array}$ \\
\hline Test Contents & $\mathrm{N} / \mathrm{A}$ & $\mathrm{N} / \mathrm{A}$ & Flour \& Fluorescein \\
\hline Seal Type & N/A & N/A & Polished* \\
\hline Closure Cap Torque & N/A & N/A & $25 \mathrm{ft}-\mathrm{lb}$ \\
\hline Start Time & N/A & $\mathrm{N} / \mathrm{A}$ & $10: 11: 33$ \\
\hline End Time & N/A & N/A & $10: 16: 34$ \\
\hline Breakaway Torque & N/A & N/A & $\begin{array}{l}\text { started @ } 50, \\
\text { broke@25=25 ft-lb }\end{array}$ \\
\hline $\begin{array}{c}\text { Fluorescein/Moisture: } \\
\text { Seal } \\
\text { Gasket } \\
\text { Threads } \\
\text { Inside }\end{array}$ & N/A & N/A & $\begin{array}{l}\mathrm{Y} \\
\mathrm{Y} \\
\mathrm{Y} \\
\mathrm{N}\end{array}$ \\
\hline
\end{tabular}


HNF-3099 Rev. 0

Table 3-5. Test \#3-- Scrub Test Using Water Saturated Rags.

\begin{tabular}{|l|l|l|l|}
\hline & \multicolumn{1}{|c|}{$\begin{array}{c}\text { Test Specimen: } \\
\text { C-PP10 }\end{array}$} & \multicolumn{1}{|c|}{$\begin{array}{c}\text { Test Specimen: } \\
\text { C-PP11 }\end{array}$} & \multicolumn{1}{c|}{$\begin{array}{c}\text { Test Specimen: } \\
\text { C-PP12 }\end{array}$} \\
\hline $\begin{array}{c}\text { Galling: } \\
\text { Threads } \\
\text { Seal }\end{array}$ & N/A & N/A & $\mathrm{N}$ \\
\hline Result of Test & N/A & N/A & Pass \\
\hline Comments & *A fabricated seal was to be used for this test; however, the fabricated \\
& $\begin{array}{l}\text { seal would not fit over the threads of the cap so a polished seal was } \\
\text { used instead. }\end{array}$ \\
& $\begin{array}{l}\text { Moisture, flour, and fluorescein were found on the upper portion of } \\
\text { the cap threads, about half-way down onto the cap. Test results were } \\
\text { considered acceptable to establish a minimum decontamination } \\
\text { requirement. }\end{array}$ \\
\hline
\end{tabular}

\subsubsection{Heat/Water Spray Test (Modification 2)}

Upon completion of Test \#3, it was determined that the Heat/Water Spray Test (Modification 1) that was conducted as Test \#2 would be conducted next (as Test \#4) with the following additional criteria:

(1) The cap and body interface would be cleaned and polished for all test specimens

(2) No gasket would be used

(3) The test specimen will be filled $75-80 \%$ full with heated quartz crystals.

This test will be identified as Heat/Water Spray Test (Modification 2). The following information represents the data collected during testing:

Table 3-6. Test \#4 -- Heat/Water Spray Test (Modification 2).

\begin{tabular}{|l|l|l|l|}
\hline & \multicolumn{1}{|c|}{$\begin{array}{c}\text { Test Specimen: } \\
\text { C-PP10 }\end{array}$} & $\begin{array}{c}\text { Test Specimen: } \\
\text { C-PP11 }\end{array}$ & \multicolumn{1}{c|}{$\begin{array}{c}\text { Test Specimen: } \\
\text { C-PP12 }\end{array}$} \\
\hline Test Contents & $\begin{array}{l}\text { Heated quartz } \\
\text { crystals }\end{array}$ & N/A & N/A \\
\hline Seal Type & None & N/A & N/A \\
\hline
\end{tabular}


HNF-3099 Rev. 0

Table 3-6. Test \#4 -- Heat/Water Spray Test (Modification 2).

\begin{tabular}{|c|c|c|c|}
\hline & $\begin{array}{l}\text { Test Specimen: } \\
\text { C-PP10 }\end{array}$ & $\begin{array}{c}\text { Test Specimen: } \\
\text { C-PP11 }\end{array}$ & $\begin{array}{c}\text { Test Specimen: } \\
\text { C-PP12 }\end{array}$ \\
\hline $\begin{array}{l}\text { Heated Container } \\
\text { Temp (Oven) }\end{array}$ & $200.8^{\circ} \mathrm{C}\left(393.4^{\circ} \mathrm{F}\right)$ & N/A & N/A \\
\hline Initial Cap Torque & $\mathrm{N} / \mathrm{A}$ & N/A & $\mathrm{N} / \mathrm{A}$ \\
\hline $\begin{array}{l}\text { Cooled Test } \\
\text { Specimen Temp. }\end{array}$ & $83.3^{\circ} \mathrm{C}\left(182^{\circ} \mathrm{F}\right)$ & N/A & $\mathrm{N} / \mathrm{A}$ \\
\hline Verified Cap Torque & $25 \mathrm{ft}-\mathrm{lb}$ & N/A & N/A \\
\hline Retorque Required & No & N/A & N/A \\
\hline $\begin{array}{l}\text { Water Container } \\
\text { Height } \\
\end{array}$ & 4 to $5 \mathrm{ft}$ range & N/A & N/A \\
\hline Period I Start Time & $2: 58: 21$ & N/A & N/A \\
\hline Period 1 End Time & $3: 01: 22$ & N/A & N/A \\
\hline Period 2 Start Time & $3: 01: 27$ & N/A & N/A \\
\hline Period 2 End Time & $3: 03: 28$ & N/A & $\mathrm{N} / \mathrm{A}$ \\
\hline Breakaway Torque & $\begin{array}{l}\text { started @ } 50, \\
\text { broke@ } 29=21 \mathrm{ft}-1 \mathrm{~b}\end{array}$ & $\mathrm{~N} / \mathrm{A}$ & $\mathrm{N} / \mathrm{A}$ \\
\hline $\begin{array}{c}\text { Fluorescein/Moisture: } \\
\text { Seal } \\
\text { Gasket } \\
\text { Threads } \\
\text { Inside }\end{array}$ & $\begin{array}{l}\mathrm{Y} \\
\mathrm{N} / \mathrm{A} \\
\mathrm{Y} \\
\mathrm{N}\end{array}$ & N/A & N/A \\
\hline $\begin{array}{l}\text { Galling: } \\
\text { Threads } \\
\text { Seal }\end{array}$ & $\begin{array}{l}\mathrm{N} \\
\mathrm{N}\end{array}$ & N/A & $\mathrm{N} / \mathrm{A}$ \\
\hline Result of Test & Pass & N/A & N/A \\
\hline Comments & \multicolumn{3}{|c|}{$\begin{array}{l}\text { There was an indication of one drop of water/fluorescein mixture at } \\
\text { the lid/body interface. Moisture followed the threads of the cap. No } \\
\text { moisture or leakage was indicated inside the container body. }\end{array}$} \\
\hline
\end{tabular}


HNF-3099 Rev. 0

\subsubsection{Heat/Water Immersion Test (Modification 1)}

Test \#5 and \#6 were conducted as a modified Heat/Water Immersion Test (Modification 1) from that described in Section 6.3 of the Test Plan. Modifications were made during this test as follows:

(1) No gasket would be used

(2) The test specimens will be filled $75-80 \%$ full with coarse salt crystals

(3) Test specimen C-PP11 will be topped with approximately 1 tablespoon of baking flour.

The following information represents the data collected during testing:

Table 3-7. Test \#5 and \#6-- Heat/Water Immersion Test (Modification 1).

\begin{tabular}{|l|l|l|l|}
\hline & \multicolumn{1}{|c|}{$\begin{array}{c}\text { Test Specimen: } \\
\text { C-PP10 }\end{array}$} & \multicolumn{1}{|c|}{$\begin{array}{c}\text { Test Specimen: } \\
\text { C-PP11 }\end{array}$} & \multicolumn{1}{|c|}{$\begin{array}{c}\text { Test Specimen: } \\
\text { C-PP12 }\end{array}$} \\
\hline Test Sequence & N/A & Test \#6 & Test \#5 \\
\hline Test Contents & N/A & $\begin{array}{l}\text { Coarse salt crystals } \\
\text { and flour }\end{array}$ & Coarse salt crystals \\
\hline Seal Type & N/A & None & None \\
\hline $\begin{array}{l}\text { Heated Container } \\
\text { Temp (Oven) }\end{array}$ & N/A & $201.5^{\circ} \mathrm{C}\left(394.7^{\circ} \mathrm{F}\right)$ & $201.4^{\circ} \mathrm{C}\left(394.5^{\circ} \mathrm{F}\right)$ \\
\hline Initial Cap Torque & N/A & $25 \mathrm{ft}-\mathrm{lb}$ & $25 \mathrm{ft}-\mathrm{lb}$ \\
\hline $\begin{array}{l}\text { Cooled Test } \\
\text { Specimen Temp. }\end{array}$ & N/A & $98.9^{\circ}\left(210^{\circ} \mathrm{F}\right)$ & $100^{\circ} \mathrm{C}\left(212^{\circ} \mathrm{F}\right)$ \\
\hline Verified Cap Torque & N/A & $25 \mathrm{ft}-\mathrm{lb}$ & $25 \mathrm{ft}-\mathrm{lb}$ \\
\hline Retorque Required & N/A & Yes & Yes \\
\hline Water Temp. & N/A & Not requested & Not requested \\
\hline Immersion Depth & N/A & $8 \mathrm{ft}, 8$ in. & $8 \mathrm{ft}, 8$ in. \\
\hline Start Time & N/A & $2: 12: 30$ & $1: 18.54$ \\
\hline End Time & $2: 17: 31$ & $1: 23: 55$ \\
\hline
\end{tabular}


HNF-3099 Rev. 0

Table 3-7. Test \#5 and \#6-- Heat/Water Immersion Test (Modification 1).

\begin{tabular}{|c|c|c|c|}
\hline & $\begin{array}{c}\text { Test Specimen: } \\
\text { C-PP10 }\end{array}$ & $\begin{array}{c}\text { Test Specimen: } \\
\text { C-PP11 }\end{array}$ & $\begin{array}{l}\text { Test Specimen: } \\
\text { C-PP12 }\end{array}$ \\
\hline Breakaway Torque & N/A & $\begin{array}{l}\text { started@95, } \\
\text { broke@30=35 ft-lb }\end{array}$ & $\begin{array}{l}\text { started } @ 90, \\
\text { broke } @ 0=90 \mathrm{ft}-\mathrm{lb}\end{array}$ \\
\hline $\begin{array}{l}\text { Fluorescein/Moisture: } \\
\text { Seal } \\
\text { Gasket } \\
\text { Threads } \\
\text { Inside }\end{array}$ & N/A & $\begin{array}{l}\mathrm{Y} \\
\mathrm{N} / \mathrm{A} \\
\mathrm{Y} \\
\mathrm{Y}\end{array}$ & $\begin{array}{l}\mathrm{Y} \\
\mathrm{N} / \mathrm{A} \\
\mathrm{Y} \\
\mathrm{N}^{1}\end{array}$ \\
\hline $\begin{array}{l}\text { Galling: } \\
\text { Threads } \\
\text { Seal }\end{array}$ & $\mathrm{N} / \mathrm{A}$ & $\begin{array}{l}\mathrm{N} \\
\mathrm{N}\end{array}$ & $\begin{array}{l}Y^{2} \\
Y^{2}\end{array}$ \\
\hline Result of Test & N/A & Fail & Fail \\
\hline
\end{tabular}


HNF-3099 Rev. 0

Table 3-7. Test \#5 and \#6-- Heat/Water Immersion Test (Modification 1).

\begin{tabular}{|c|c|c|c|}
\hline & $\begin{array}{c}\text { Test Specimen: } \\
\text { C-PP10 }\end{array}$ & $\begin{array}{c}\text { Test Specimen: } \\
\text { C-PP11 }\end{array}$ & $\begin{array}{l}\text { Test Specimen: } \\
\text { C-PP12 }\end{array}$ \\
\hline Comments & \multicolumn{3}{|c|}{$\begin{array}{l}\text { Test \#5 (C-PP12): Moisture was indicated on the underside of cap } \\
\text { and about } 3 / 4 \text { of the way down on the cap threads. Inside was } \\
\text { questionable because under black light inspection some of the crystals } \\
\text { looked illuminant and tinted a very light greenish color. It could not } \\
\text { be determined if the light green color was caused by a change in the } \\
\text { crystals due to the extreme heat, or if fluorescein had actually come in } \\
\text { contact with the crystals. Therefore, the following comparisons were } \\
\text { performed: } \\
\text { 1) Checked the salt crystals (under a black light) from the test unit and } \\
\text { could not determine if the change in the color of the salt crystals was } \\
\text { due to heat or possible fluorescein. } \\
\text { 2) Checked only heated salt crystals (under a black light) and they } \\
\text { looked similar to the salt crystals noted in Item } 1 \text { above. } \\
\text { 3) Checked "clean" unheated salt crystals (under a black light) and } \\
\text { they were a pinkish color. } \\
\text { 4) Checked tested salt crystals from Item \#1 above and added } \\
\text { approximately } 5-6 \text { drops of water/fluorescein mixture to these } \\
\text { crystals. Under black light inspection the fluorescein was easily } \\
\text { detected. } \\
\text { 'It was believed that Test \#5 (C-PP12) did not have any in-leakage of } \\
\text { water and fluorescein and that it passed. } \\
\text { 2However, after this test unit was transferred to the } 306 \text { Facility for } \\
\text { polishing, the BWHC Project Engineer noted that galling of the lid } \\
\text { and body interface did occur. However, there was no galling of the } \\
\text { threads. This was a fail. } \\
\text { Test \#6 (C-PP11): Approximately } 1 / 4 \text { teaspoon of moisture was } \\
\text { present inside the Container body and sides. Moisture was also } \\
\text { detected on the flour that was added to top of salt crystals. }\end{array}$} \\
\hline
\end{tabular}


HNF-3099 Rev. 0

\subsubsection{Heat/Water Spray Test (Modification 3)}

Test \#7 was conducted as the Heat/Water Spray Test (Modification 3) to verify the results found and documented under Test \#4. Test \#7 was conducted the same as Test \#4, and included the following modifications:

(1) The cap and body interface would be cleaned and polished for all test specimens

(2) No gasket would be used

(3) The test specimen will be filled $75-80 \%$ full with coarse crystal salt.

The following information represents the data collected during testing:

Table 3-8. Test \#7 -- Heat/Water Spray Test (Modification 3).

\begin{tabular}{|c|c|c|c|}
\hline & $\begin{array}{l}\text { Test Specimen: } \\
\text { C-PP10 }\end{array}$ & $\begin{array}{l}\text { Test Specimen: } \\
\text { C-PP11 }\end{array}$ & $\begin{array}{c}\text { Test Specimen: } \\
\text { C-PP12 }\end{array}$ \\
\hline Test Contents & Coarse crystal salt & N/A & N/A \\
\hline Seal Type & None & N/A & N/A \\
\hline $\begin{array}{l}\text { Heated Container } \\
\text { Temp (Oven) }\end{array}$ & $201.4^{\circ} \mathrm{C}\left(394.5^{\circ} \mathrm{F}\right)$ & N/A & N/A \\
\hline Initial Cap Torque & Hand tight & $\mathrm{N} / \mathrm{A}$ & N/A \\
\hline $\begin{array}{l}\text { Cooled Test } \\
\text { Specimen Temp. }\end{array}$ & $104.4^{\circ} \mathrm{C}\left(220^{\circ} \mathrm{F}\right)$ & N/A & $\mathrm{N} / \mathrm{A}$ \\
\hline Verified Cap Torque & $25 \mathrm{ft}-\mathrm{lb}$ & N/A & $\mathrm{N} / \mathrm{A}$ \\
\hline Retorque Required & N/A & $\mathrm{N} / \mathrm{A}$ & N/A \\
\hline $\begin{array}{l}\text { Water Container } \\
\text { Height }\end{array}$ & $4 \mathrm{ft}$ & N/A & N/A \\
\hline Water Temperature & $31.1^{\circ} \mathrm{C}\left(88^{\circ} \mathrm{F}\right)$ & N/A & N/A \\
\hline Period 1 Start Time & $10: 18: 15$ & N/A & N/A \\
\hline Period 1 End Time & $10: 20: 30$ & N/A & N/A \\
\hline Period 2 Start Time & $10: 20: 34$ & $\mathrm{~N} / \mathrm{A}$ & N/A \\
\hline Period 2 End Time & $10: 22: 35$ & $\mathrm{~N} / \mathrm{A}$ & N/A \\
\hline
\end{tabular}


HNF-3099 Rev. 0

Table 3-8. Test \#7 -- Heat/Water Spray Test (Modification 3).

\begin{tabular}{|c|c|c|c|}
\hline & $\begin{array}{c}\text { Test Specimen: } \\
\text { C-PP10 }\end{array}$ & $\begin{array}{c}\text { Test Specimen: } \\
\text { C-PP11 }\end{array}$ & $\begin{array}{l}\text { Test Specimen: } \\
\text { C-PP12 }\end{array}$ \\
\hline Breakaway Torque & $\begin{array}{l}\text { started @ } 90 \\
\text { broke@69=21 ft-lb }\end{array}$ & N/A & N/A \\
\hline $\begin{array}{c}\text { Fluorescein/Moisture: } \\
\text { Seal } \\
\text { Gasket } \\
\text { Threads } \\
\text { Inside }\end{array}$ & $\begin{array}{l}\mathrm{Y} \\
\mathrm{N} / \mathrm{A} \\
\mathrm{Y} \\
\mathrm{Y}\end{array}$ & $\mathrm{N} / \mathrm{A}$ & $\mathrm{N} / \mathrm{A}$ \\
\hline $\begin{array}{l}\text { Galling: } \\
\text { Threads } \\
\text { Seal }\end{array}$ & $\begin{array}{l}\mathrm{N} \\
\mathrm{Y}\end{array}$ & $\mathrm{N} / \mathrm{A}$ & $\mathrm{N} / \mathrm{A}$ \\
\hline Result of Test & Fail & N/A & N/A \\
\hline Comments & \multicolumn{3}{|c|}{$\begin{array}{l}\text { Moisture was detected approximately } 1-1 / 4 \text { in. deep within the } \\
\text { capsule, beginning } 1 / 2 \text { in. beyond the threads. Approximately } 5 \text { drops } \\
\text { were noted below the threads. The threads of the capsule and lid had } \\
\text { moisture throughout. Moisture was detected on the interface surface } \\
\text { of the lid and capsule. There was a slight detection of fluorescein on } \\
\text { the top portion of the salt. Galling was noted on the mating surface of } \\
\text { the lid and container. }\end{array}$} \\
\hline
\end{tabular}

\subsubsection{Heat/Scrub Test Using Water Saturated Rags (Modification 1)}

Test \#8, \#9, and \#10 were conducted and are titled as the Heat/Scrub Test Using Water Saturated Rags (Modification 1). This test is modified from the Scrub Test Using Water Saturated Rags that was used to perform Test \#3 (conducted per Appendix B, Section B.3). This test includes a combination of steps performed under Section 6.3 and Section B.3, and includes the following steps:

(1) The test specimens will be cleaned, have a cleaned body and cap interface, and be polished

(2) Any galling noted during previous testing shall be determined to not affect the results of additional testing

(3) The test specimens will not include a gasket

(4) The test specimens will be filled with coarse salt until approximately $75-80 \%$ full 
HNF-3099 Rev. 0

(5) The test specimens will be heated to approximately $200^{\circ} \mathrm{C}\left(392^{\circ} \mathrm{F}\right)$

(6) The closure cap will be hand-tightened onto the container body

(7) The test specimen will be free-air cooled to approximately $100^{\circ} \mathrm{C}\left(212^{\circ} \mathrm{F}\right)$

(8) Test specimen lids will be torqued to $20 \mathrm{ft}$-lbs instead of $25 \mathrm{ft}-\mathrm{lbs}$

(9) Test specimens will have a water and fluorescein mixture washed over them at the seal area using a saturated rag for a period of 5 minutes.

Table 3-9. Test \#8, \#9, and \#10 --

Heat/Scrub Test Using Water Saturated Rags (Modification 1).

\begin{tabular}{|c|c|c|c|}
\hline & $\begin{array}{l}\text { Test Specimen: } \\
\text { C-PP10 }\end{array}$ & $\begin{array}{l}\text { Test Specimen: } \\
\text { C-PP11 }\end{array}$ & $\begin{array}{l}\text { Test Specimen: } \\
\text { C-PP12 }\end{array}$ \\
\hline Test Sequence & Test \#10 & Test \#9 & Test \#8 \\
\hline Test Contents & Coarse salt crystals & Coarse salt crystals & Coarse salt crystals \\
\hline Seal Type & None & None & None \\
\hline $\begin{array}{l}\text { Heated Container } \\
\text { Temp (Oven) }\end{array}$ & $196^{\circ} \mathrm{C}\left(384.8^{\circ} \mathrm{F}\right)$ & $201.5^{\circ} \mathrm{C}\left(394.7^{\circ} \mathrm{F}\right)$ & $201.8^{\circ} \mathrm{C}\left(395.2^{\circ} \mathrm{F}\right)$ \\
\hline Initial Cap Torque & Hand tight & Hand tight & Hand tight \\
\hline $\begin{array}{l}\text { Cooled Test } \\
\text { Specimen Temp. }\end{array}$ & $109.4^{\circ} \mathrm{C}\left(229^{\circ} \mathrm{F}\right)$ & $100^{\circ} \mathrm{C}\left(212^{\circ} \mathrm{F}\right)$ & $103.9^{\circ} \mathrm{C}\left(219^{\circ} \mathrm{F}\right)$ \\
\hline Verified Cap Torque & $20 \mathrm{ft}-\mathrm{lb}$ & $20 \mathrm{ft}-\mathrm{lb}$ & $20 \mathrm{ft}-\mathrm{lb}$ \\
\hline Retorque Required & $\mathrm{N} / \mathrm{A}$ & $\mathrm{N} / \mathrm{A}$ & $\mathrm{N} / \mathrm{A}$ \\
\hline Start Time & $2: 39: 15$ & $2: 01: 15$ & $1: 24: 44$ \\
\hline End Time & $2: 44: 17$ & 2:06:30 & $1: 29: 46$ \\
\hline Breakaway Torque & $\begin{array}{l}\text { started @ } 90, \\
\text { broke @ } 70=20 \mathrm{ft}-\mathrm{lb}\end{array}$ & $\begin{array}{l}\text { started @ } 90, \\
\text { broke@70=20 ft-lb }\end{array}$ & $\begin{array}{l}\text { started @ } 90 \\
\text { broke@ } 65=25 \mathrm{ft}-\mathrm{lb}\end{array}$ \\
\hline $\begin{array}{c}\text { Fluorescein/Moisture: } \\
\text { Seal } \\
\text { Gasket } \\
\text { Threads } \\
\text { Inside }\end{array}$ & $\begin{array}{l}\mathrm{Y} \\
\mathrm{N} / \mathrm{A} \\
\mathrm{Y} \\
\mathrm{Y}\end{array}$ & $\begin{array}{l}\mathrm{Y} \\
\mathrm{N} / \mathrm{A} \\
\mathrm{Y} \\
\mathrm{Y}\end{array}$ & $\begin{array}{l}\mathrm{Y} \\
\mathrm{N} / \mathrm{A} \\
\mathrm{Y} \\
\mathrm{N}\end{array}$ \\
\hline
\end{tabular}


HNF-3099 Rev, 0

Table 3-9. Test \#8, \#9, and \#10 --

Heat/Scrub Test Using Water Saturated Rags (Modification 1).

\begin{tabular}{|c|c|c|c|}
\hline & $\begin{array}{l}\text { Test Specimen: } \\
\text { C-PP10 }\end{array}$ & $\begin{array}{l}\text { Test Specimen: } \\
\text { C-PP11 }\end{array}$ & $\begin{array}{l}\text { Test Specimen: } \\
\text { C-PP12 }\end{array}$ \\
\hline $\begin{array}{l}\text { Galling: } \\
\text { Threads } \\
\text { Seal }\end{array}$ & $\begin{array}{l}\mathrm{N} \\
\mathrm{N}\end{array}$ & $\begin{array}{l}\mathrm{N} \\
\mathrm{N}\end{array}$ & $\begin{array}{l}\mathrm{N} \\
\mathrm{N}\end{array}$ \\
\hline Result of Test & Fail & Fail & Pass \\
\hline Comments & \multicolumn{3}{|c|}{$\begin{array}{l}\text { Test \#8 (C-PP12): Moisture was noted at the lid/body interface and } \\
\text { on the threads. No moisture was detected inside the container upon } \\
\text { black light inspection. } \\
\text { Test \#9 (C-PP11): Air suction (i.e., vacuum) was heard when the } \\
\text { Container was opened. One drop of moisture was detected } \\
\text { approximately } 1 / 4 \text { in. down into the container. One drop of moisture } \\
\text { was noted inside the container wall; however the lid was pulled off } \\
\text { quickly and there is a possibility that the drop fell from the lid/thread } \\
\text { area into the container. No fluorescein was detected in the salt } \\
\text { crystals. } \\
\text { Test \#10 (C-PP10): Moisture was detected at the lid/body interface, } \\
\text { threads, and inside the container wall. Fluorescein was detected on } \\
\text { approximately } 10 \text { salt crystals. }\end{array}$} \\
\hline
\end{tabular}

\subsubsection{Heat/Scrub Test Using Water Dampened Rags (Modification 1)}

Test \#11, \#12, and \#13 were conducted and are titled as the Heat/Scrub Test Using Water Dampened Rags (Modification 1). This test is modified from the Scrub Test Using Water Dampened Rags identified as Appendix B, Section B.4. This test includes a combination of steps performed under Section 6.3 and Section B.4, and includes the following steps:

(1) The test specimens will be cleaned, have a cleaned body and cap interface, and be polished

(2) Any galling noted during previous testing shall be determined to not affect the results of additional testing

(3) The test specimens will not include a gasket

(4) The test specimens will be filled with coarse salt until approximately $75-80 \%$ full 
HNF-3099 Rev. 0

(5) The test specimens will be heated to approximately $200^{\circ} \mathrm{C}\left(392^{\circ} \mathrm{F}\right)$

(6) The closure cap will be hand-tightened onto the container body

(7) The test specimen will be free-air cooled to approximately $100^{\circ} \mathrm{C}\left(212^{\circ} \mathrm{F}\right)$

(8) Test specimen lids will be torqued to $20 \mathrm{ft}-\mathrm{lbs}$ instead of $25 \mathrm{ft}-\mathrm{lbs}$

(9) A rag will be saturated with a water and fluorescein mixture and wrung-out until damp. The dampened rag will be scrubbed over the test specimen at the seal area for a period of 5 minutes.

Table 3-10. Test \#11, \#12, and \#13 -Heat/Scrub Test Using Water Dampened Rags (Modification 1).

\begin{tabular}{|c|c|c|c|}
\hline & $\begin{array}{c}\text { Test Specimen: } \\
\text { C-PP10 }\end{array}$ & $\begin{array}{c}\text { Test Specimen: } \\
\text { C-PP11 }\end{array}$ & $\begin{array}{c}\text { Test Specimen: } \\
\text { C-PP12 }\end{array}$ \\
\hline Test Sequence & Test \#11 & Test \#12 & Test \#13 \\
\hline Test Contents & Coarse salt crystals & Coarse salt crystals & Coarse salt crystals \\
\hline Seal Type & None & None & None \\
\hline $\begin{array}{l}\text { Heated Container } \\
\text { Temp (Oven) }\end{array}$ & $199^{\circ} \mathrm{C}\left(390.2^{\circ} \mathrm{F}\right)$ & $200.5^{\circ} \mathrm{C}\left(392.9^{\circ} \mathrm{F}\right)$ & $200.5^{\circ} \mathrm{C}\left(392.9^{\circ} \mathrm{F}\right)$ \\
\hline Initial Cap Torque & Hand tight & Hand tight & Hand tight \\
\hline $\begin{array}{l}\text { Cooled Test } \\
\text { Specimen Temp. }\end{array}$ & $100^{\circ} \mathrm{C}\left(212^{\circ} \mathrm{F}\right)$ & $100^{\circ} \mathrm{C}\left(212^{\circ} \mathrm{F}\right)$ & $100^{\circ} \mathrm{C}\left(212^{\circ} \mathrm{F}\right)$ \\
\hline Verified Cap Torque & $20 \mathrm{ft}-1 \mathrm{~b}$ & $20 \mathrm{ft}-\mathrm{lb}$ & $20 \mathrm{ft}-\mathrm{lb}$ \\
\hline Retorque Required & $\mathrm{N} / \mathrm{A}$ & $\mathrm{N} / \mathrm{A}$ & $\mathrm{N} / \mathrm{A}$ \\
\hline Start Time & $14: 38: 00$ & $14: 48: 30$ & $15: 05: 25$ \\
\hline End Time & 14:43:05 & $14: 53: 35$ & $15: 10: 30$ \\
\hline Breakaway Torque & $\begin{array}{l}\text { started @ } 90, \\
\text { broke @ } 75=15 \mathrm{ft}-\mathrm{lb}\end{array}$ & $\begin{array}{l}\text { started @ } 90, \\
\text { broke @ } 74=16 \mathrm{ft}-\mathrm{lb}\end{array}$ & $\begin{array}{l}\text { started@90, } \\
\text { broke@75=15 ft-lb }\end{array}$ \\
\hline $\begin{array}{c}\text { Fluorescein/Moisture: } \\
\text { Seal } \\
\text { Gasket } \\
\text { Threads } \\
\text { Inside }\end{array}$ & $\begin{array}{l}\mathrm{N} \\
\mathrm{N} / \mathrm{A} \\
\mathrm{N} \\
\mathrm{N}\end{array}$ & $\begin{array}{l}N \\
N / A \\
N \\
N\end{array}$ & $\begin{array}{l}\mathrm{N} \\
\mathrm{N} / \mathrm{A} \\
\mathrm{N} \\
\mathrm{N}\end{array}$ \\
\hline
\end{tabular}


HNF-3099 Rev. 0

Table 3-10. Test \#11, \#12, and \#13 --

Heat/Scrub Test Using Water Dampened Rags (Madification 1).

\begin{tabular}{|c|l|l|l|}
\hline & \multicolumn{1}{|c|}{$\begin{array}{c}\text { Test Specimen: } \\
\text { C-PP10 }\end{array}$} & $\begin{array}{r}\text { Test Specimen: } \\
\text { C-PP11 }\end{array}$ & $\begin{array}{c}\text { Test Specimen: } \\
\text { C-PP12 }\end{array}$ \\
\hline Galling: & & & $\mathrm{N}$ \\
Threads & $\mathrm{N}$ & $\mathrm{N}$ & $\mathrm{N}$ \\
\hline Seal & $\mathrm{N}$ & $\mathrm{N}$ & Pass \\
\hline Result of Test & Pass & Pass & \\
\hline Comments & No moisture detected and no galling indicated. \\
\hline
\end{tabular}

\subsection{REFERENCES}

HNF-2399, Design, Fabrication, and Assembly Criteria for Cesium Powder and Pellet Inner Containers, B\&W Hanford Company, Richland, Washington, April 6, 1998. (Note: This document was undergoing revision at the time the test report documentation was being approved for release.)

HNF-2945, Cesium Powder and Pellets Inner Container Decontamination Method

Determination Test, Waste Management Federal Services, lnc., Northwest Operations, Richland, Washington, July 9, 1998.

Task Order Agreement Contract E42800, Task Order SW826, Preparation of a Performance Test Plan and Performance Test of Cesium Powder and Pellet Inner Container, BWHC9854672, May 28, 1998. 


\section{HNF-3099 Rev. 0}

This page intentionally left blank. 
HNF-3099 Rev. 0

APPENDIX A

TEST PLAN - FIELD COPY DOCUMENTATION

A-1 
HNF-3099 Rev. 0

This page intentionally left blank. 


\begin{tabular}{l}
\hline 2. To: (Receiving organization) \\
BWHC - 324 Projects \\
\hline 5. Proj./Prog./Dept./div.: \\
BWHC - 324 Projects (K4C25) \\
(WMNW: $772030 / 40-054-001)$ \\
\hline
\end{tabular}

8. Originator Remarks:

\section{Frems coriginating orgonizotion) Packaging Engineering (03E00) \\ 6. Dexign Authority/ Design Agent/Cog. Engr.: \\ SD Landsman, Cog. Engr., BWHC}

\begin{tabular}{|} 
4. Related EDT NO.: \\
NA \\
7. Purchase order No.: \\
NA \\
$\begin{array}{c}\text { 9. Equip./Componant No.: } \\
\text { NA }\end{array}$ \\
10. System/Bidg./Faeility: \\
NA \\
\hline 12. Major Assm. DWg. No.: \\
NA
\end{tabular}

13. Permit/Permit Application No.: NA

16. Required Reaponse Date: ple $7 / 9 / 98$

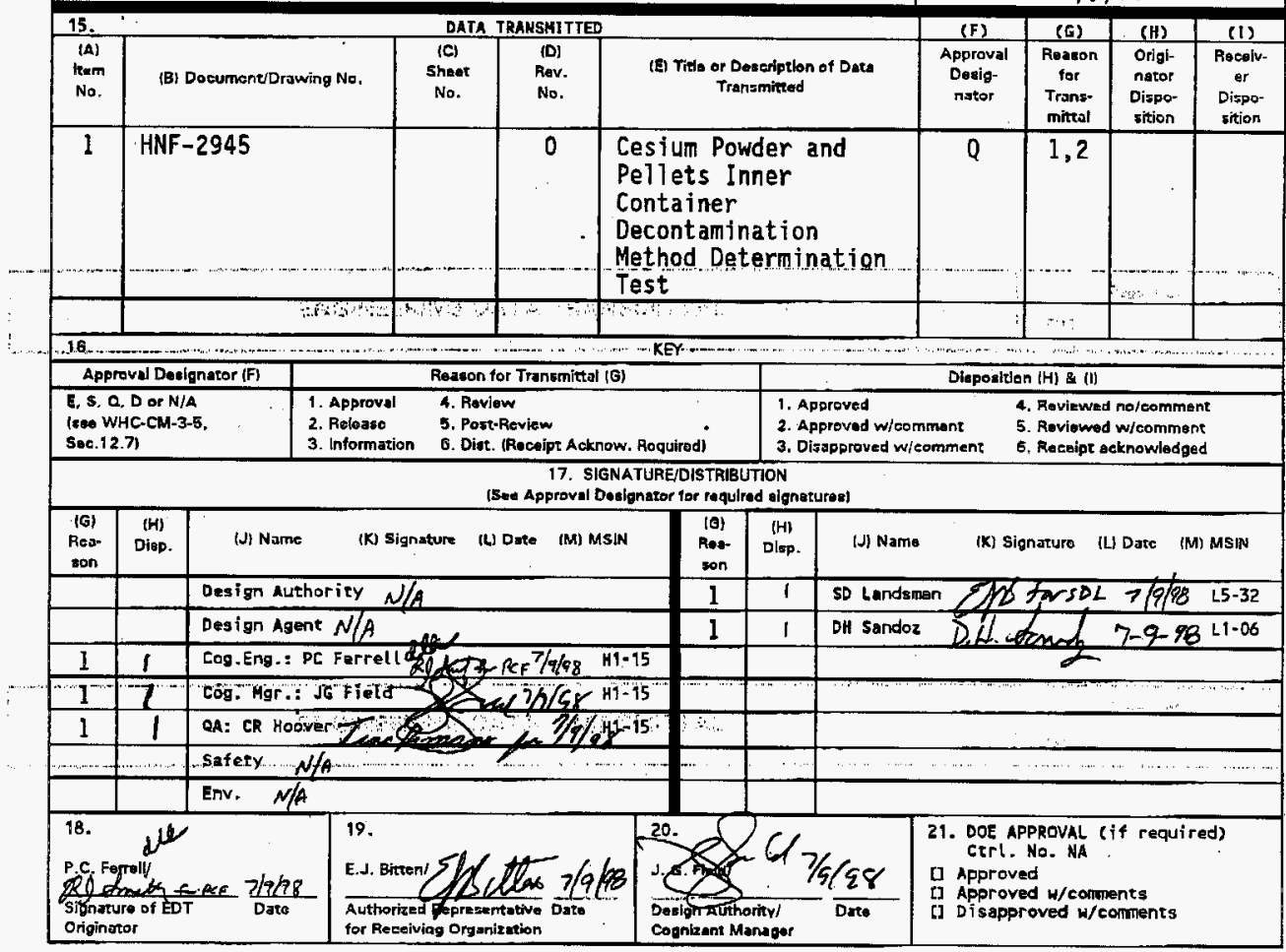


HNF-3099 Rev. 0

\section{Cesium Powder and Pellets Inner Container Decontamination Method Determination}

P. C. Ferre11

Waste Management Federal Services Inc., Northwest Operations, Richland, WA 99352

U.S. Department of Energy Contract DE-AC06-96RL13200

EDT/ECN: EDT 622374

Org Code: O3E00

BQR Code: EW7050000
UC: 513

Charge Code: K4C25 (772030/40-054-001)

Total Pages: 30

Key Words: Cesium Powder and Pellets, Inner Container, Decontamination.

Abstract: The Cesium Powder and Pellets Inner Container is to be performance tested per the criteria specified in Section 4.0 of HNF-2399, "Design, Fabrication, and Assembly Criteria for Cesjum Powder and Pellet Inner Container." The test criteria specifies that the Inner Container be water tight during decontamination of the exterior surface. Three prototypes will be immersed into a pool of water to simulate a water decontamination process.

TRADEMARK DISCLAIMER. Reference herein to any specific comercial product, proeess, or service by trade name, tradenark, manufacturer, or otherwise, does not necessarily constitute or imply its endorsement, recohorendation, or favoring by the United States Goverrment or any agency thereof or its contractors or subcontractors.

Printed in the United states of America. To obtain copies of this document, contact: Document Control Services, P.O. Box 950, Mailstop H6-08, Richland wh 97352, Phone (509) 372-2420; Fax (509) 376-4989.
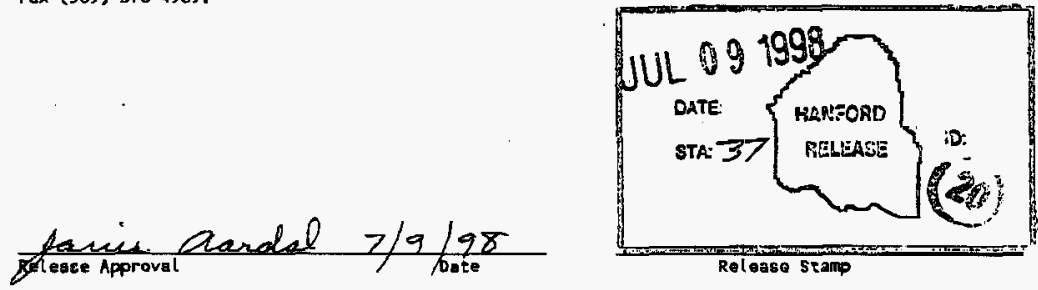
1.0 PURPOSE AND SCOPE $\ldots \ldots \ldots \ldots \ldots \ldots \ldots \ldots \ldots \ldots \ldots \ldots$

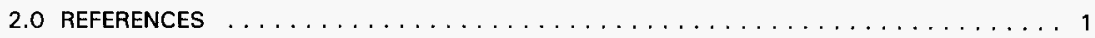

3.0 GENERAL REQUIREMENTS $\ldots \ldots \ldots \ldots \ldots \ldots \ldots \ldots \ldots \ldots \ldots \ldots \ldots \ldots \ldots$

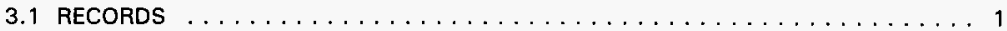

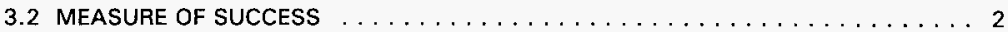

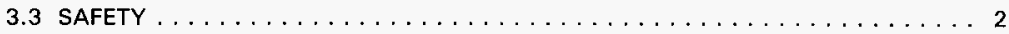

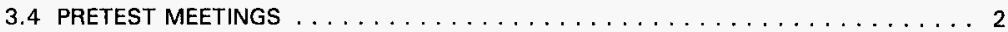

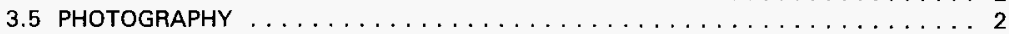

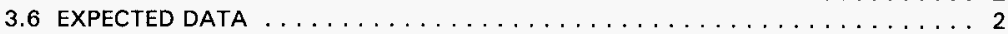

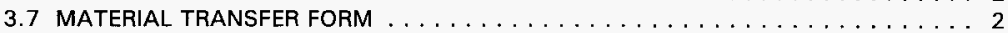

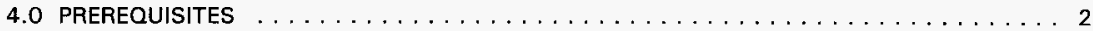

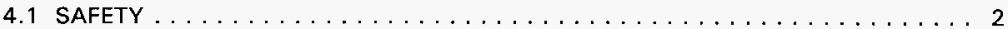

4.2 PERSONNEL REQUIREMENTS $\ldots \ldots \ldots \ldots \ldots \ldots \ldots \ldots \ldots \ldots \ldots \ldots \ldots \ldots$

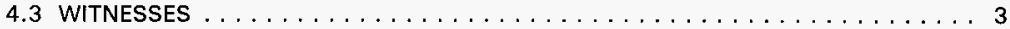

5.0 TEST EQUIPMENT $\ldots \ldots \ldots \ldots \ldots \ldots \ldots \ldots \ldots \ldots \ldots \ldots \ldots$

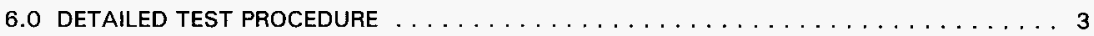

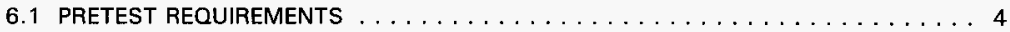

6.2 PREPARATION OF TEST SPECIMENS $\ldots \ldots \ldots \ldots \ldots \ldots \ldots \ldots \ldots \ldots \ldots$

6.3 HEAT/WATER IMMERSION TEST $\ldots \ldots \ldots \ldots \ldots \ldots \ldots \ldots \ldots \ldots$

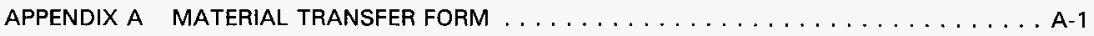

APPENDIX B OPTIONAL TESTS $\ldots \ldots \ldots \ldots \ldots \ldots \ldots \ldots \ldots \ldots \ldots \ldots \ldots$

APPENDIX C ADDITIONAL WATER IMMERSION TESTING

DUE to TORQUE VALUE CHANGE $\ldots \ldots \ldots \ldots \ldots \ldots \ldots \ldots \ldots \ldots$

\section{LIST OF TERMS}

$\begin{array}{ll}\text { BWHC } & \text { B\&W Hanford Company } \\ \text { QA } & \text { Quality Assurance } \\ \text { OC } & \text { Quality Control } \\ \text { WMNW } & \text { Waste Management Federal Services, Inc., Northwest Operations }\end{array}$


HNF-3099 Rev. 0

HNE-2945- Rev. O

\section{OFFICIAL COFY}

This page intentionally left blank. 
HNF-3099 Rev. 0

HNE-2945 ReV. 0

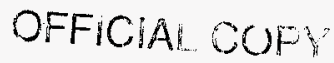

\section{CESIUM POWDER AND PELLETS INNER CONTAINER DECONTAMINATION METHOD DETERMINATION TEST}

\subsection{PURPOSE AND SCOPE}

The Cesium Powder and Pellets Inner Container is to be performance tested per the criteria specified in Section 4.0 of HNF-2399, Design, Fabrication, and Assembly Criteria for Cesium Powder and Pellet Inner Container and Task Order SW826. The test criteria specifies that the Inner Container be water tight during decontamination of the exterior surface.

The decontamination method determination test will consist of heating, cooling, then immersing three prototype Inner Containers in a pool of water to simulate a water decontamination process. Due to the concern of condensate, the pool of water will contain a leak detection agent (fluorescein). Any in-leakage detection of the fluorescent water to the Inner Container will constitute container seal failure. Additional optional tests are identified in Appendices B and C of this test procedure. The tests will be conducted by the Numatec Hanford Company in the 305 Building.

This procedure may be modified at any time by the mutual decision of the Waste Management Federal Services, Inc., Northwest Operations (WMNW) test engineer and the B\&W Hanford Company (BWHC) project engineer and Quality Assurance (OA) representative. The results of such a decision shall be written in red (permanent type) ink on the original test procedure and initialed and dated by the aforementioned parties. At the conclusion of the test, any changes will be incorporated into the document with an engineering change notice.

\subsection{REFERENCES}

HNF-2399, Design, Fabrication, and Assembly Criteria for Cesium Powder and Pellet Inner Containers, B\&W Hanford, Company, Richland, Washington, March 18, 1998.

Task Order Agreement Contract E42800, Task Order SW826, Preparation of a Performance Test Plan and Performance Test of Cesium Powder and Pellet Inner Container, BWHC-9854672, May 28, 1998.

\subsection{GENERAL REQUIREMENTS}

\subsection{RECORDS}

The WMNW test engineer shall mark one copy of this test procedure, for the testing organization, with the words "Official Copy." The official copy shall be used to record the WMNW test engineer's or the designee's signature, signifying completion of the procedure steps. The completed official copy will be given to BWHC for retention. All entries will be signed and dated. All other test data will be placed into the test file, and maintained in accordance with Project Hanford Management Contract records management requirements. 
The WMNW test engineer will prepare a test report summarizing the test results. A summary table depicting test data will be included into the test report. The report, after being signed by the WMNW test engineer and the BWHC project engineer and QA representative, will be distributed to all involved personnel and the customer.

\subsection{MEASURE OF SUCCESS}

The performance test will be successful when all pretest activities, tests, and post-test activities are completed and recorded in an accurate manner.

\subsection{SAFETY}

The test facility shall be responsible for reviewing and establishing safety requirements for its portion of the tests.

\subsection{PRETEST MEETINGS}

Prior to testing, the facility test engineer or designee shall conduct a pretest meeting with all test personnel to review the test procedure and schedule for the day. Safety requirements shall be reviewed along with any special instructions.

\subsection{PHOTOGRAPHY}

The test facility at the 305 Building shall be responsible for providing photographic evidence of each test setup and the test results.

\subsection{EXPECTED DATA}

The expected data obtained from these tests shall consist of still pictures, written observations from visual examinations, and the completed test procedures, including equipment calibration data and test details.

\subsection{MATERIAL TRANSFER FORM}

The BWHC Material Transfer Form (included in Appendix A) shall be completed anytime the test units change custody or building locations. In addition, a copy of the form shall be provided to the BWHC project engineer or designee by the individual receiving the test units.

\subsection{PREREQUISITES}

\subsection{SAFETY}

All test operations shall be conducted in a safe and approved manner by authorized personnel. The facility test engineer shall be responsible for approving, authorizing, and maintaining the safety of personnel and equipment at the test facility. The facility test engineer shall review procedures with all test personnel at the start of each test series. 
HNF-3099 Rev. 0

HNF-2945 - ReV. O

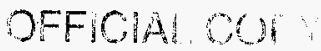

\subsection{PERSONNEL REQUIREMENTS}

All test personnel shall have received any required special training prior to participating in the tests. All test operations shall be conducted by authorized personnel. A copy of the test procedures shall be reviewed by all test personnel at the start of each test.

The Quality Control $(\mathrm{OC})$ representative, whose signature indicates observation and acceptance of satisfactory completion of any or all test conditions identified in this test procedure, shall have current Level II qualification/certification in the Basic and Mechanical Inspection disciplines. Copies of certifications shall be included in the data package for each signatory QC representative witnessing the included testing activities of these tests.

\subsection{WITNESSES}

All required test procedure signature points will be signed off and witnessed by the WMNW test engineer, the BWHC project engineer (or designee), and the BWHC OC representative for each test. The $Q C$ representative shall verify and record the current calibration status and acceptable indicating range for each instrument used for establishing test conditions and recording of data. Test conditions and parameters shall be verified as acceptable and will be implicit in the $\mathrm{QC}$ representative signature following the completion of each test.

\subsection{TEST EQUIPMENT}

The test equipment will be provided by the 305 Building facility or by BWHC. All test equipment shall be currently calibrated, and a copy of the calibration sheets shall be provided to the WMNW test engineer. The test specimens will be provided by BWHC.

\subsection{DETAILED TEST PROCEDURE}

The Inner Container is designed to hold Cesium parts and pieces and provide a water tight seal during decontamination of its external surface. If changes need to be taken during testing , these steps will be documented within this test plan, and concurrence will be provided by the WMNW test engineer, BWHC project engineer (or designee), and the BWHC OC representative, A decision point has been added after each section to determine how to proceed.

To demonstrate the sealing capabilities of the Inner Container seal, three prototypic Inner Containers will be subjected to a heat/water immersion test. The Container will be heated to an approximate temperature, and the closure cap will be placed onto each Container then torqued to $25 \mathrm{ft}-\mathrm{lbs}$. The test specimen will be cooled to an approximate temperature and placed into a pool of water that contains a leak-detection agent (fluorescein). If no in-leakage of fluorescein water into the Inner Container is observed, additional testing will not be required.

If fluorescein water in-leakage is detected the Inner Containers will be cleaned out, and the Inner Containers will be subjected to an optional water immersion test. The closure cap on each Inner Container will be torqued to $25 \mathrm{ft}$-lbs. If no leakage of water into the Inner Container is observed, additional testing will not be required. 
If water in-leakage is detected the Inner Containers will be cleaned out, the closure cap on each on each Inner Container will be torqued to $25 \mathrm{ft}-\mathrm{lbs}$, and the Inner Containers will be subjected to an 2-minute water wash from a hose attached to a water container that is 4 feet above the elevation the test is conducted at. If no leakage of water is detected, additional testing will not be required.

If water in-leakage is detected the Inner Containers will be cleaned out, the closure cap on each Inner Container will be torqued to $25 \mathrm{ft}$-lbs and the containers will be subjected to a vigorous scrub using water saturated rags for a period of 5 minutes. If no leakage of water is detected, additional testing will not be required.

If water in-leakage is detected the inner Containers will be cleaned out, the closure cap on each Inner Container will be torqued to $25 \mathrm{ft}-\mathrm{lbs}$ and the containers will be subjected to a vigorous 5-minute scrub using dampened rags. If no leakage of water is detected, additional testing will not be required.

If water in-leakage is detected, BWHC Cesium Legacy project management will be consulted to determine path forward. Optional test procedures provided in Appendix B. If BWHC Cesium Legacy project management determines that a higher torque value is to be tested, follow the additional water immersion test procedure provided in Appendix $\mathrm{C}$.

A copy of the test results will be forwarded to BWHC Cesium Legacy cognizant engineer upon successful completion of the test procedure.

\subsection{PRETEST REQUIREMENTS}

The following items will be verified prior to starting the test.

1. The lid and body of each test specimen shall be permanently and uniquely marked to ensure traceability of the test specimen throughout the test. The identification marking of the lid for each test specimen shall match the identification marking of the test specimen body.

2. The BWHC material transfer form (included in Appendix A) shall be completed, and a copy of this form shall be provided to the BWHC project engineer or designee by the recipient of the test specimens.

3. Each test specimen shall be fabricated to drawing $\mathrm{H}-3-307832$.

4. Test apparatus is ready and instruments are calibrated.

All requirements specified in Section 6.1 are completed. Authorization is granted to assemble the test specimens and start the test.
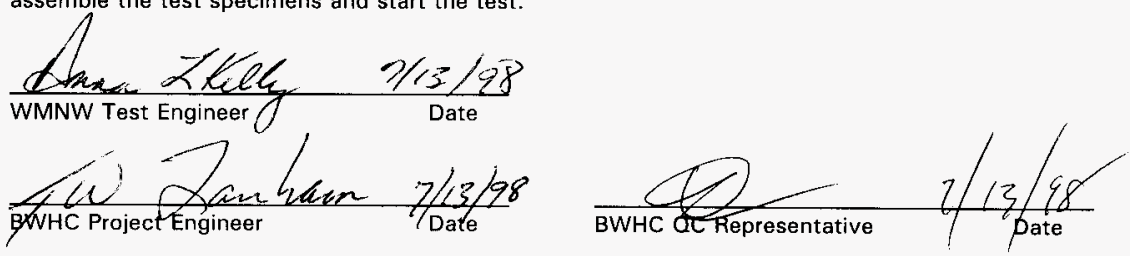
HNF-3099 Rev. 0

HNF 2945 Rev. $-\theta$

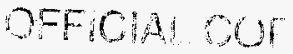

\subsection{PREPARATION OF TEST SPECIMENS}

1. Ensure that each test specimen is clean and dry.

All test specimen preparation requirements specified in Section 6.2 are completed. Authorization is granted to start the test.
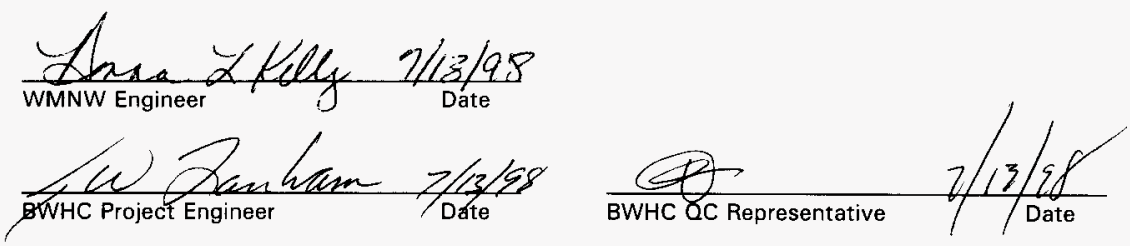

\subsection{HEAT/WATER IMMERSION TEST}

\section{TEST NUMBER 1}

The heat/water immersion test consists of heating the test specimens to approximately $200^{\circ} \mathrm{C}\left(392^{\circ} \mathrm{F}\right)$, placing the closure cap onto each Container and torquing the cap to $25 \mathrm{ft}-\mathrm{lbs}$. The test specimen will be free-air cooled to approximately $100^{\circ} \mathrm{C}\left(212^{\circ} \mathrm{F}\right)$ and the closure cap torque reverified to $25 \mathrm{ft}$-lbs. The specimen will then be placed into a pool of water that contains a leakdetection agent (fluorescein). The test specimens will be placed into the water to a depth of $8.1 \mathrm{ft}$ $(+0.5 /-0 \mathrm{ft})$ for a period of at least 5 minutes. After the test, the closure cap will be removed and the inside of the test specimen will be examined for in-leakage of fluorescein water. In addition, the threads and seals will be inspected for galling. The detailed procedure follows.

1. Heat the Container to approximately $200^{\circ} \mathrm{C}\left(392^{\circ} \mathrm{F}\right)$ and remove from oven. (The closure cap will not be heated.) Record the temperature in the table below.

2. Install the closure cap and polished seal on the test specimen. Using the BWHC provided spanner, torque the closure cap to $25 \mathrm{ft}-\mathrm{lbs}$. Record torque wrench calibration information, test specimen torque values, and type of seal below.

\begin{tabular}{|c|c|c|}
\hline Torque Wrench Identification: & $545-88-01-203$ & $s / n$ \\
\hline Next Calibration Due Date: & $2-27-99$ & \\
\hline Acceptable Rang & $+1-4 \%$ & \\
\hline
\end{tabular}


HNF-3099 Rev. 0

HNE-2945 Rer. 0

DFFICIA: OUI

\begin{tabular}{|c|c|c|c|c|c|c|}
\hline $\begin{array}{c}\text { TEST } \\
\text { SPECIMEN } \\
\text { NUMBER }\end{array}$ & $\begin{array}{l}\text { TYPE OF SEAL } \\
\text { INSTALLED }\end{array}$ & $\begin{array}{l}\text { HEATED } \\
\text { CONTAINER } \\
\text { TEMP. }\end{array}$ & $\begin{array}{c}\text { INITIAL } \\
\text { CLOSURE } \\
\text { CAP } \\
\text { TOROUE } \\
\text { VALUE }\end{array}$ & $\begin{array}{l}\text { COOLED } \\
\text { TEST } \\
\text { SPEC. } \\
\text { TEMP. }\end{array}$ & $\begin{array}{c}\text { VERIFIED } \\
\text { CLOSURE } \\
\text { CAP } \\
\text { TORQUE } \\
\text { VALUE }\end{array}$ & $\begin{array}{c}\text { RE- } \\
\text { TORQUE } \\
\text { REQ'D } \\
(\mathbf{Y} / \mathbf{N})\end{array}$ \\
\hline C-PP10 & Polished & $\begin{array}{l}394 \text { incied } \\
326 \text { out }(F)\end{array}$ & $25 \mu t=16$ & $166(\mathrm{~F})$ & $35 \mathrm{kth}$ & $\csc 2$ \\
\hline \multicolumn{7}{|l|}{ C-PP11 } \\
\hline C-PP12 & & & & & & \\
\hline
\end{tabular}

3. Free-air cool the test specimen to approximately $100^{\circ} \mathrm{C}\left(212^{\circ} \mathrm{F}\right)$. Record the temperature in the table above.

4. Verify that the torque on the closure cap is $25 \mathrm{ft}$-lbs. Re-torque to $25 \mathrm{ft}$-lbs if needed. Record the verified closure cap torque value in the table above, and indicate if re-torquing was required.

5. Place the test specimen into an appropriate holder and lower the specimen into the pool of fluorescent water to a depth of $8.1 \mathrm{ft}(+0.5,-0 \mathrm{ft}$ ) (use 8 feet, 8 inches). The immersion depth is measured from the top of the water to the upper most surface of the test specimen. Hold the test specimen at the prescribed depth for at least 5 minutes. Remove the test specimen. This test will be conducted on all three test specimens. Record the following:

\#) Test Specimen: $C-P P 10$

Immersion Depth: 8ff - S in.

Start Time:

$11: 36: 16$

End Time:

11:41:28

Test Specimen:

Immersion Depth:

Start Time:

End Time:

Test Specimen:

Immersion Depth:

Start Time:

End Time:

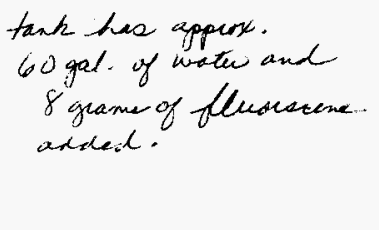


6. After the test is completed, towel dry the test specimen to remove any visible moisture on the external surfaces. Pay particular attention to the seal area to ensure all moisture is removed.

7. Remove the closure cap from each test specimen. Record the breakaway torque value below for each test specimen as appropriate.

\#1 \begin{tabular}{|c|c|}
\hline TEST SPECIMEN NUMBER & BREAKAWAY TOROUE VALUE \\
\hline C-PP10 & etactedla 50-broke awey 9 \\
\hline C-PP11 & \\
\hline C-PP12 & \\
\hline
\end{tabular}

8. Visually examine the interior of each test specimen for in-leakage of fluorescent water. If needed, use a black light. Use the table below to note any fluorescein detection to the seal area, gasket, threads, and inside the test specimen. Use the table below to note any gualling of the threads or sealing surface. In addition, record any additional information as needed for documentation purposes.

\begin{tabular}{|c|c|c|c|c|c|c|c|}
\hline \multirow{2}{*}{$* \begin{array}{c}\text { TEST SPECIMEN } \\
\text { NUMBER }\end{array}$} & \multicolumn{4}{|c|}{ FLUORESCEIN/MOISTURE } & \multicolumn{2}{c|}{ GALLING } \\
\hline & SEAL & GASKET & THREADS & INSIDE & THREADS & SEAL \\
\hline C-PP10 & $y$ & $y$ & $y$ & $y$ & $N$ & $N$ \\
\hline C-PP11 & & & & & & \\
\hline C-PP12 & & & & & & \\
\hline
\end{tabular}

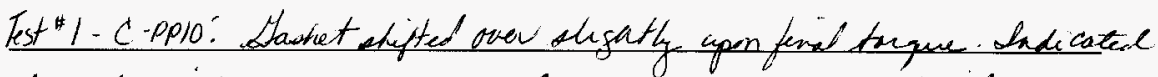

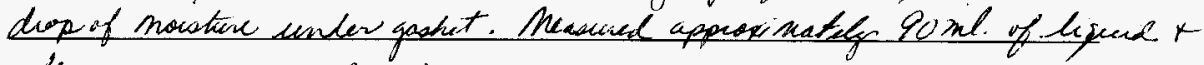
Herovare inaide Covtranes.

$\frac{\text { Dhana } 2 \text { kely }}{\text { WMNW Test Enginee }} \frac{2-3.98}{\text { Date }}$
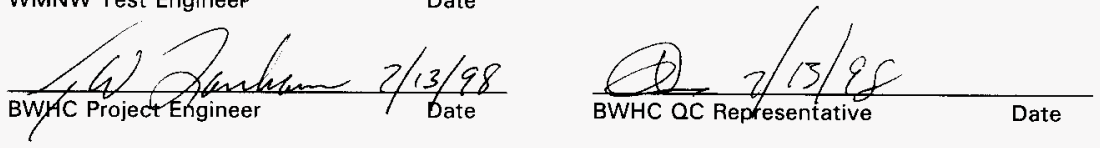
HNF-3099 Rev. 0

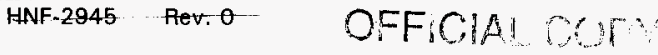

9. If galling is found, determine if it will affect the results of any additional testing.

10. If no in-leakage of fluorescent water is found and additional testing will be performed, proceed to Appendix B.

11. If additional testing will not be performed, clean the test specimens to remove the fluorescein, and notify the BWHC project engineer for disposition of the test specimens.

Test * 2 will be conducted and consists of a Combination of steps provided in section 6.3 (Heat/ Water immersion Tot) and Section B.2 (Water Spray Lat). Per 324 Pries Inge, BWHCt. to to Section B. 2 of procedure.
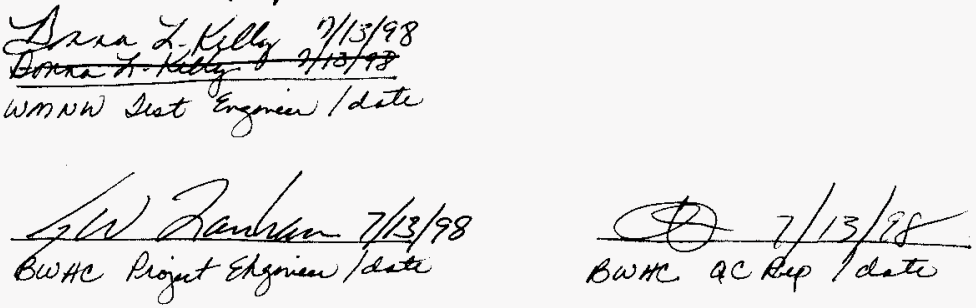

A-14 
HNF-3099 Rev. 0

HNF-2945 - Rov O OFICIAI OCI

APPENDIX A

MATERIAL TRANSFER FORM

DRIVER/CARRIER

DATE

MATERIAL/ITEM NO.

RECEIVED FROM

DATE

DELIVER TO

DATE

ACCEPTED BY

DATE

REMARKS

OC VERIFICATION BY

DATE 
HNF-3099 Rev. 0

HNF $=2845$ - Rev. $\theta$
OFFICH OU

This page intentionally left blank. 
DRIVER/CARRIER Gany Lunhan DATE $6 / 24 / 98$ MATERIALITEM NO.

WESF INNER CAPSULES C-APIO, C.PPII, and C-PPIR with Top end caps $t$ seals

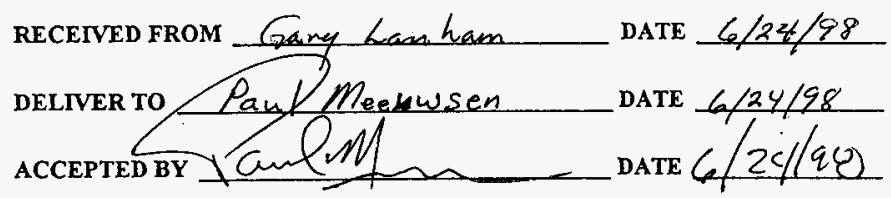
REMARKS Delivered to 305 bldg for water integrity testing.

QC VERIFICATION BY

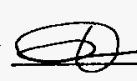
$\operatorname{Date} 6 / 2 \%$

$2 / 11 / 98$

ATTACHMENT \# B3 
ORIGINA

HNF-3099 Rev. 0

MATERIAL TRANSFER FORM

DRVERTARRIER G.Landen

DATE $2 / 14 / 98$

MATERLALTTEM No.

WESF inner tubes sub-Assemblies ceplo, c-ppll adc-ppi2

RECEIVED FROM Paul Meenusen DATE $7 / 4 / 98$ deliverto Th Delucche Date Zliy/s8 Accepted вy $\cong a$ Qleceh h DAтE 2/.4/98 rEMARKs for Cleanup.

QC VERIFICATION BY

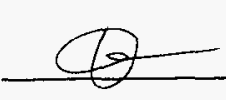
DATE $1 / 14 / 98$

A-18 
ORTGINA

HNF-3099 Rev. 0

MATERIAL TRANSFER FORM

DRIVERCARRER C Lemhaem DATE $7 / 14 / 58$

MATERHALTTEM NO.

WESE jumer tube Sub-assembly
CPP 10

RECENED FROM TA Alucchi DATE $714 / 98$

DeIIVER to faul plewwsen Datr $\frac{7 / 14 / 58}{7 / 14 / 98}$

REMARKS L L Terting.

QC VERIFICATION BY

Date $7 / 10 / 28$

A- 19 
$\underset{\text { HNF-3099 Rev. } 0}{\text { ORIGINE OFFCIA COPY }}$

MATERIAL TRANSFER FORM

DRIVERCARRER $G$ Lanhan DATE $7 / 15 / 98$

MATERLAL/TEM NO.

Ben wess innen Capsule Subassemblies

C.pplo, c-ppll, cepp/2
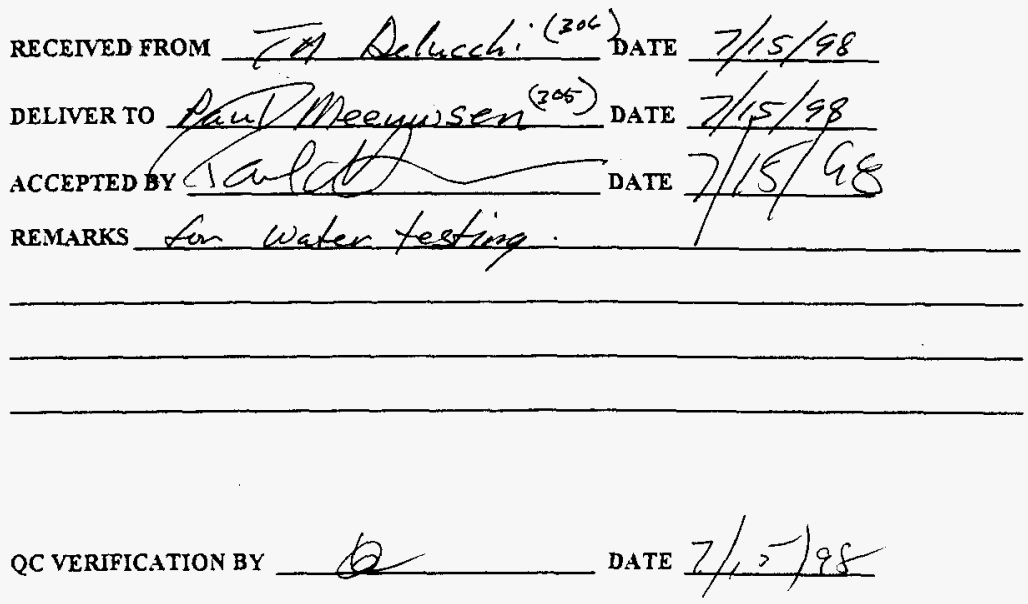

A-20 
$\underset{\text { HNF-3099 Rev. } 0}{\text { ORTGINA }}$ OFFCIAL CUPY

MATERIAL TRANSFER FORM

DRIVERCARRIER Gany Lanham DATE Z7/6/98

MATERLALTTEM NO.

WESF inien tubes sub-assenblies

C-Ppll, $C-$-Pp 12

RECEIVED FROM taul Meenwsen (jo5) DATE 7 (J64)

dentver to TA. Delucchi. (306) Date $7 / 14 / 98$

accepted ay LeP Petten

DATE $2 / 10 / 98$

REMARKS for Cleano up. Suntaces.

QC VERIFICATION BY
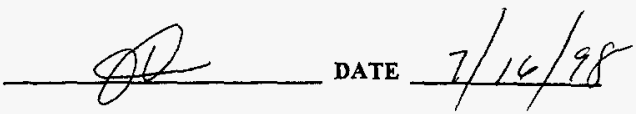

A-21 


\section{ORTGINA: \\ HNF-3099 Rev. 0 \\ DFFCIAL COPY}

\section{MATERIAL TRANSFER FORM}

DRIVERCARRIER Tany Lanham DATE $7 / 14 / 88$

MATERIAL/TEM NO.

WESE inuer tubes. Subassemblies

GPPII, C-PPI2

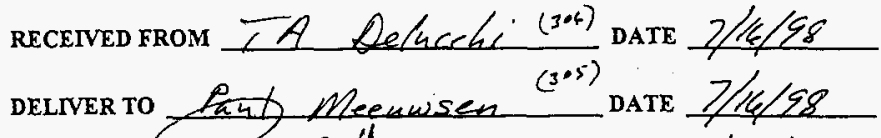

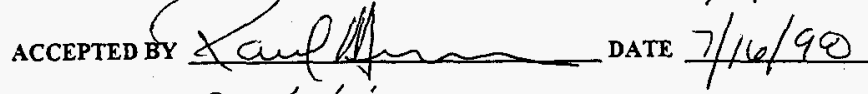
REMARKS ofs testing

QC VERIFICATION BY

Date $7 / 1 C / 98$ 
ORIGTNA

HNF-3099 Rev. 0

OFFICIA OOF

MATERIAL TRANSFER FORM

DRIVERCARRIER Gavy Laukam DATE 7 lia/g8

MATERLAL/TEM NO.

WESF thenen tube Subassenbly

CPPPO.

recenved from Paul Meenwsen date $7 / 1 a / 98$

Deliver to $\frac{T \text { Delucchi }}{\text { Date } \geq 14 / 98}$

REMARKS for Cheanup of Seabis Sunfaces.

QC VERIFICATION BY DATE

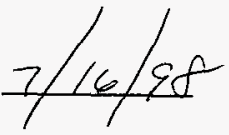

A- 23 
ORIGINA:

HNF-3099 Rev 0 OFFICALCOFY

MATERIAL TRANSFER FORM

DRIERCARRER Gamy Lanham DATE $7 / 16 / 98$ MATERIAL/ITEM NO.

wiESF luner tube. Sub-assembly CPP/O

receIved From TA Delucchi DATE $7 / 14 / 98$ dedrver to Paul Meeuarsen DATE $7 / 14 / 98$

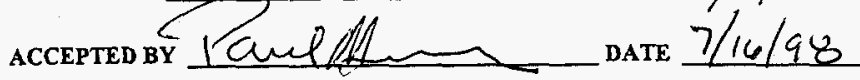
REMARKs Return to water Testing.

QC VERTFICATION BY DATE $2 / 14 / 98$

A-24 
ORIGINA:

HNF-3099 Rev. 0

OFFICIAL CUFY

MATERIAL TRANSFER FORM

$3: 35 \mathrm{pm}$.

DRRERTCARrer Gany Lanhan DATE Zfte/s8 MATERIALITEM NO.

WESF inner tubes, Sub-assmblies,

$$
\text { Ceppo, cippll Cepp/2 }
$$

recerved from Paul Meenusen (35) DATE $7 / 16 / 98$ denrver to IA Aelucchi (306) Date $7 / 16 / 98$ ACCEPTED BY myon dawetted DATE 2-17-98 REMARKS for Clean up of seating Sumfaces.

QC VERIFICATION BY DATE

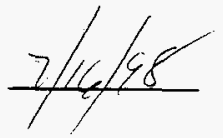

A-25

Ar 
ORIGINA

HNF-3099 Rev. 0

official COH:

MATERIAL TRANSFER FORM

DRrverCarRIER Gany Lauhan DATE $7 / 12 / 58$

MATERIAL/TEM NO.

WESE vinex tubes, Sub-assemblies

CPPIO, CAPll and CPPI2

recerved From _A Adurehi

DATE $7 / 2 / 98$

deliver to Paul Meeniusen

DATE $\frac{7 / 17 / 98}{2 / 17 / 98}$

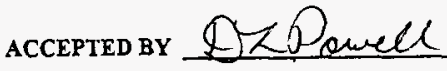
REMARKS Peturn far Testing.

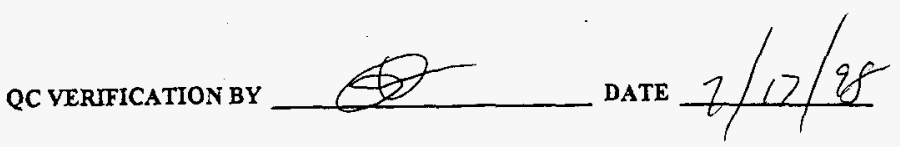

A-26

14 
HNF-3099 Rev. 0

HNF-2945 Rev. $\theta$

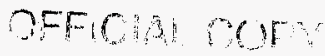

APPENDIX B

OPTIONAL TESTS

\section{B. 1 OPTIONAL WATER IMMERSION TEST}

If optional water immersion tests are desired, proceed with the following steps.

\section{B.1.1 Preparation of Test Specimens}

A mixture of flour and fluorescein will be placed in each of the test units and the closure cap and seal will be installed and torqued. The flour and fluorescein mixture will aid in the detection of any water that may leak into the test specimens. The detailed preparation procedures are as follows.

1. Ensure that each test specimen is clean and dry.

2. Determine if any galling found will affect the result of this test.

3. Prepare three mixtures of $1 / 4$ cup flour and $1 / 4$ tsp fluorescein. Place one mixture into each test specimen.

NOTE: Caution should be used to ensure that none of the mixture comes in contact with the test specimen outer surface or closure threads.

4. Install the closure cap and seal on each test specimen. Ensure that the identification marking of the lid mates with the identification marking of the body. On one test specimen use a BWHC fabricated seal; on the other two test specimens use BWHC procured seals. Using the BWHC provided spanner, torque each closure cap to $25 \mathrm{ft}$-lbs. Record torque wrench calibration information, test specimen torque values, and type of seal below.

Torque Wrench Identification:

Next Calibration Due Date:

Acceptable Range:

\begin{tabular}{|c|c|c|}
\hline TEST SPECIMEN NUMBER & $\begin{array}{c}\text { TYPE OF SEAL } \\
\text { INSTALLED }\end{array}$ & $\begin{array}{c}\text { CLOSURE CAP } \\
\text { TORQUE VALUE }\end{array}$ \\
\hline C-PP10 & & \\
\hline C-PP11 & & \\
\hline C-PP12 & & \\
\hline
\end{tabular}

5. If needed, clean the external surface of the test specimens. 
HNF-3099 Rev. 0

HNF-2945 FEV. 0

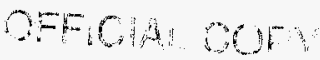

Alk test specimen preparation requirements specified in Section B.1.1 are completed. Authorization is granted to start the test.

WMNW Test Engineer Date

BWHC Project Engineer

Date

BWHC OC Representative

Date

\section{B.1.2 Optional Water Immersion Test}

\section{TEST NUMBER}

The optional water immersion test consists of placing the test specimens in a pool of water to a depth of 8.1 feet for two periods of at least 5 minutes each. After the test, the closure caps will be removed and the inside of each test specimen will be examined for water. In addition, the threads and seals will be inspected for galling. The detailed procedure follows.

NOTE: The water temperature of the immersion pool and the test facility air temperature will be verified prior to the start of this test. If additional steps need to be taken during testing to ensure that a vacuum is not created within the Inner container, these steps will be documented within this test plan, and concurrence will be provided by the WMNW test engineer, BWHC project engineer (or designee), and the BWHC QC representative.

\begin{tabular}{|c|c|c|}
\hline TEST SPECIMEN NUMBER & $\begin{array}{c}\text { TEMPERATURE OF } \\
\text { POOL }\end{array}$ & $\begin{array}{c}\text { BLDG AIR } \\
\text { TEMPERATURE }\end{array}$ \\
\hline C-PP10 & & \\
\hline C-PP11 & & \\
\hline C-PP12 & & \\
\hline
\end{tabular}

1. Place the three test specimens in an appropriate holder and lower the specimens into the pool of water to a depth of 8.1 feet $(+0.5,-0 \mathrm{ft}$ ) (use 8 feet, 8 inches). The immersion depth is measured from the top of the water to the upper most surface of the test specimens. Hold the test specimens at the prescribed depth for at least 5 minutes. Remove the test specimens and repeat the immersion test for another period of at least 5 minutes. Record the following:

\section{Period 1}

Immersion Depth:

Start Time:

End Time:

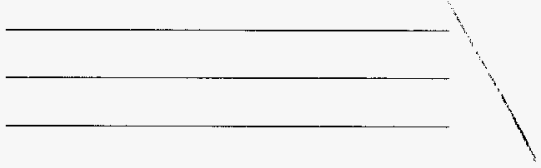


HNF-3099 Rev. 0

HNF-2945 Rev. $O$

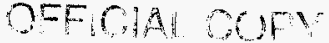

\section{Period 2}

Immersion Depth:

Start Time:

End Time:

2. After the test is completed, towel dry the test specimens to remove any visible moisture on the external surfaces. Pay particular attention to the seal area to ensure all moisture is removed.

3. Remove the closure cap from each test specimen. Record the breakaway torque value below for each test specimen as appropriate.

\begin{tabular}{|c|c|}
\hline TEST SPECIMEN NUMBER & BREAKAWAY TORQUE VALUE \\
\hline C-PP10 & \\
\hline C-PP11 & \\
\hline C-PP12 & \\
\hline
\end{tabular}

4. Visually examine the intekijor of each test specimen for water. If needed, use a black light. Use the table below to note any moisture detection to the seal area, gasket, threads, and inside the test specimen. Use the table below to note any galling of the threads or seal. In addition, record any additional information as needed for documentation purposes.

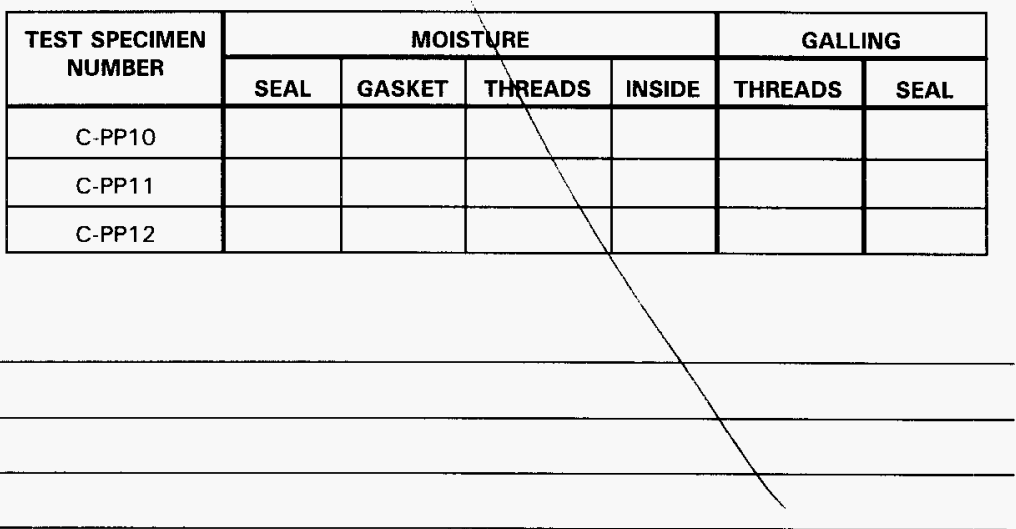


HNF-3099 Rev. 0

HNF-2945 … Rev: 0

\section{OFFICIAI YOPY}
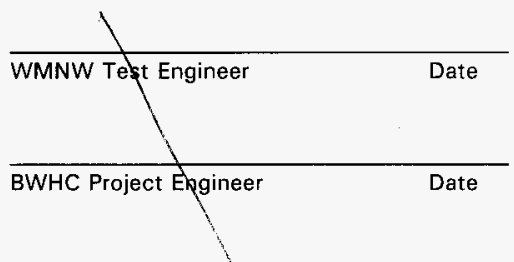

BWHC QC Representative Date

5. If gallikg is found, determine if it will affect the results of any additional testing.

6. If no water is found and additional testing will be performed, proceed to Section B.2 to continud with optional tests, or to Appendix $C$ for additional water immersion testing using a different torque value.

7. If additional testing will not be performed, clean the test specimens to remove the flour and fluorescein mixture, and notify the BWHC project engineer for disposition of the test specimens.

\section{B.2 WATER SPRAY TESTS Teat 2 (rewence}

If water spray tests are desired, proceed with the following steps.

The pretest requirements of section 6.1 (pg4) will be met puir to this tat.

the Preparation of teat specinend will be as noted in Sectim 6.23

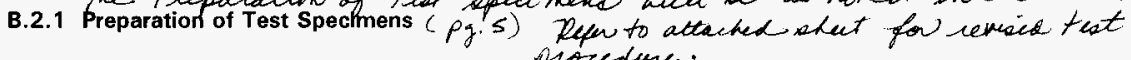

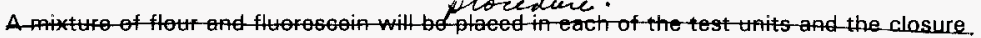
cap and seat will be ingtedted and torqued. The flour and fluoreseen with aid in the detection of any water that may loak into-the-test-specimens. Tho detailed preparation procedures follow.

1. Ensure that each test specimen is clean and dry.

2. Determine if any galling found prior to conducting this test will affect the result of this test.

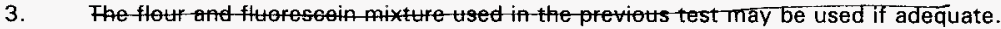
If not adequate, removo of flour and flu mixture and prepare threenew mixtures-of $1 / 4$ oup flour and $1 / 4$-tsp fluoscein. Place one mixture into each test specimen.

NOTE: Caution should be-used to-ancure that nane of tho-mixture-eomes in contact with the-test specimen outer surface or elosure threeds.

4._._. Install the elosure eap and seal on each test specimen. Ensure that the identification marking of the lid mates with the identification marking of the body. On-ono tot speimen use aWHG fabrieated seat; on the other two tost specimens use BWHC procured seals. Using the BWHC provided spanner, torque each ctorure cap to $25 \mathrm{ft}$-lbs. Recoldore wrench catibration information, test-specimen. torque values, and type of seal below. 
HNF-3099 Rev. 0

OFFICIAL COPY

Test $\# 2$

Heat l

B.2 Water Spray Tests

B.2.1 The pretext requirements of Section 6.1 (page 4 ) wien be met prim to this teat.

the flow and fluosseen mixture weir not be placed inside the test specimen

All requirements operificil in Section B.2.1 (revise) are completed. Authoigatin is granted to assemble the teat specimen and stat the test, Per 324 Project Mgr, by the.

Lana 2. Kelly 213-98

wow Teat Engines / date

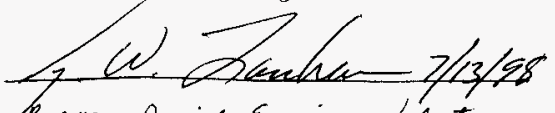

BWHC Digit Enguew/date

Heat 1

B.2.2 Water Spray Lett

Unis test consists of heating the test specimen to approximately $200^{\circ} \mathrm{C}\left(392^{\circ} \mathrm{F}\right)$, placing the closure cap onto the Container, letting the container he free -ain coaled to approximately. $100^{\circ} \mathrm{C}\left(212^{\circ} \mathrm{F}\right)$, and the clarence. Cap torqued to $25 \mathrm{ft}$-lees.

the teat specimen will then be spayed with Heworecent water. The watch spay will consist of a head. of If ft on the seal area of the contains fou two periods. of at least 2 minutes each. Apter the test, the Closure cape will be removed and the inside of each test specimen will be examined for water. In addition The threads and seals will be inspected for galling. She detailed procedure follows. 
HNF-3099 Rev. 0

Test $* 2$ (cont)

OFFICIAL COPY

1. Heat the (nitaina to apposinately $200^{\circ} \mathrm{C}\left(392^{\circ} \mathrm{F}\right)$ and remove from oven t. (The Closure cap wile hot be heated.) Record the temperature in the the below.

2. Instal closure cap and polished seal on the test aprimen. When test unit reaches apposinately $100^{\circ} \mathrm{C}\left(212^{\circ} \mathrm{F}\right)$, tongue the closure cap to $25 \mathrm{ft}$ ll s. Recon the torque wren calibistin information, tet eperimentorgue values, * type of seat below.

Torque wrench identification: $545-88-01-2025 \sin 6064$ Nest Calibration due Date:

Acceptable range:

$$
\frac{2-27-99}{1-42}
$$

Test specimen $¥: \quad \quad C-P P \| /$

type of seal installed: polvoked

Heated container tenge: $\quad 200^{\circ}$ in oven (C)

Initial Closure cap tree value: NN/A

cooled test opec. Hemp: $\quad 220^{\circ}(F)$ begin tongue $-L$ to proa

reified closure cap tongue value:

re-torgue reg'd $(Y / N)$ : to 25 ft -la.

N/A

3. Go to Section B.2.2 (original test plan), step \#1.

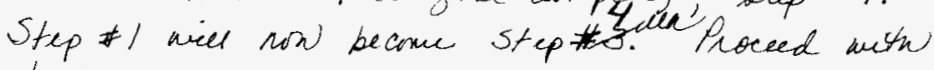
t rating.

A-32 
Torque Wrench Identification:

Next Calibration Due Date:

Acceptable Range:

\begin{tabular}{|c|c|c|}
\hline TEST SPECIMEN NUMBER & $\begin{array}{c}\text { TYPE OF SEAL } \\
\text { INSTALLED }\end{array}$ & $\begin{array}{c}\text { CLOSURE CAP } \\
\text { TOROUE VALUE }\end{array}$ \\
\hline C-PP10 & & \\
\hline C-PP11 & & \\
\hline C-PP12 & & \\
\hline
\end{tabular}

5. If needed, clean the external surface of the test specimens.

All test specimen preparation requirements specified in Section B.2.1 are completed. Authorization is granted to start the test.

WMNW Test Engineer Date

BWHC Project Engineer Date

B.2.2 Water spray test Refer to attached aheet for newied test procelue
for Test 2
TEST NUMBER 3

The water spray test consists of spraying watex yolth a head of 4 feet on the seal area of the container for two peariods of at least 2 minutes eagh. After the test, the closure caps will be remoyed and the inside of each test specimen will be examinad for water. In addition, the threads and seals will be inspected for galling. The detalled procedure fottaws.

4. 1 .

Place the three test specimens in an appropriate holder. Rig a container filled with water and equipped with a spigot in a position approximately 4 feet higher that the elevation of the top of the test specimens. Attach a 3/8-inch diameter tygon tube to the container spigot. Allow the water to gravity feed down the tube and spray the seal areas of the test specimens for a period of 2 minutes. The water container height is measured from the bottom of the water container to the upper most surface of the test specimens. At the end of the first period, refill the water container and repeat the spray test for another period of at least 2 minutes. Record the following: 
HNF-3099 Rev. 0

HNF-2945 Rev. $\theta$.

Period 1

$\frac{C-P P \|}{\text { Test } \# 2}$

Water Container Height:

Start Time:

End Time:

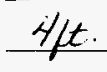

$$
\frac{2.46: 13}{2.48 \cdot 18}
$$

\section{Period 2}

Water Container Height:

Start Time:

End Time:

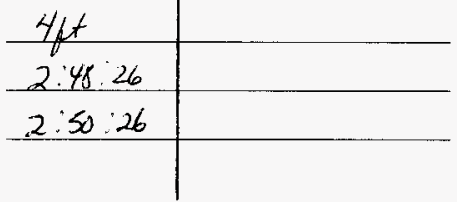

$5 \cdot 2$. After the test is completed, towel dry the test specimens to remove any visible moisture on the external surfaces. Pay particular attention to the seal area to ensure all moisture is removed.

6. B. Remove the closure cap from each test specimen. Record the breakaway torque

\begin{tabular}{|c|c|c|}
\hline & TEST SPECIMEN NUMBER & BREAKAWAY TORQUE VALUE \\
\hline \multirow{3}{*}{ Test $\# 2$ - } & C.PP10 & \\
\hline & C-PP11 & starte 50 - preak auray 63 \\
\hline & C-PP12 & \\
\hline
\end{tabular}
value below for each test specimen as appropriate.

ก. A. Visually examine the interior of each test specimen for water. If needed, use a black light. Use the table below to note any moisture detection to the seal area, gasket, threads, and inside the test specimen. Use the table below to note any galling of the threads or seal. In addition, record any additional information as

\begin{tabular}{|c|c|c|c|c|c|c|c|}
\hline & \multirow{2}{*}{$\begin{array}{l}\text { TEST SPECIMEN } \\
\text { NUMBER }\end{array}$} & \multicolumn{4}{|c|}{ MOISTURE } & \multicolumn{2}{|c|}{ GALLING } \\
\hline & & SEAL & GASKET & THREADS & INSIDE & THREADS & SEAL \\
\hline & C-PP10 & & & & & & \\
\hline$\# 2$ & C-PP11 & $y$ & $y$ & $y$ & $y$ & $N$ & $N$ \\
\hline & C-PP12 & & & & & & \\
\hline
\end{tabular}
needed for documentation purposes. 

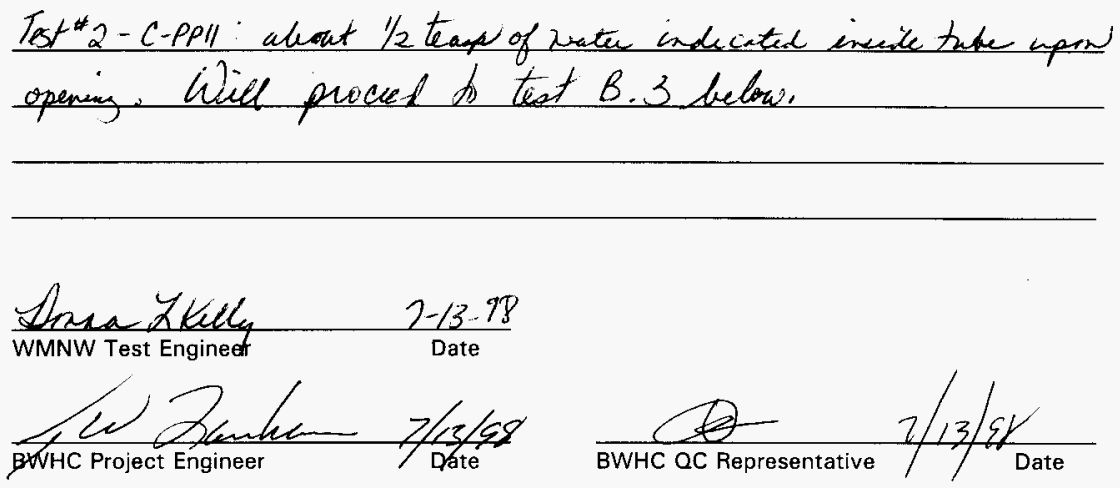

4. 5. If galling is found, determine if it will affect the results of any additional testing.

Ø. If no water is found and additional testing will be performed, proceed to Section B.3 for additional optional tests.

D. 7 . If additional testing will not be performed, clean the test specimens to remove the flour and fluorescein mixture, and notify the BWHC project engineer for disposition of the test specimens.

\section{B.3 SCRUB TEST USING WATER SATURATED RAGS}

$$
\left(\operatorname{Tec}{ }^{* 3}\right)
$$

\section{B.3.1 Preparation of Test Specimens}

A mixture of flour and fluorescein will be placed in each of the test units and the closure cap and seal will be installed and torqued. The flour and fluorescein mixture will aid in the detection of any water that may leak into the test specimens. The detailed preparation procedures follow.

1. Ensure that each test specimen is clean and dry.

2. Determine if any galling found prior to conducting this test will affect the result of this test.

3. The flour and fluorescein mixture used in the previous test may be used if adequate. If not adequate, remove the old flour and fluorescein mixture and prepare three new mixtures of $1 / 4$ cup flour and $1 / 4$ tsp fluorescein. Place one mixture into each test specimen.

NOTE: Caution should be used to ensure that none of the mixture comes in contact with the test specimen outer surface or closure threads. 


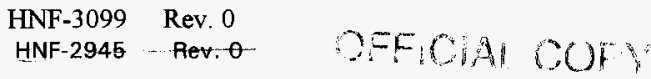

4. Install the closure cap and seal on each test specimen. Ensure that the identification marking of the lid mates with the identification marking of the body. On one test specimen use a BWHC fabricated seal; on the other two test specimens use BWHC procured seals. Using the BWHC provided spanner, torque each closure cap to $25 \mathrm{ft}$-lbs. Record torque wrench calibration information, test specimen torque values, and type of seal below.

\begin{tabular}{|c|c|}
\hline Torque Wrench Identification: & $545-88-01-20.2$ \\
\hline Next Calibration Due Date: & $2-27-99$ \\
\hline Acceptable Range: & $+1-4 \%$ \\
\hline
\end{tabular}

\begin{tabular}{|c|c|c|c|}
\hline & TEST SPECIMEN NUMBER & $\begin{array}{l}\text { TYPE OF SEAL } \\
\text { INSTALLED }\end{array}$ & $\begin{array}{l}\text { CLOSURE CAP } \\
\text { TOROUE VALUE }\end{array}$ \\
\hline & C-PP10 & & \\
\hline & C-PP11 & & \\
\hline That $\# 3$ & C.PP12 & Polshed * & $25 \mathrm{lt} / \mathrm{w}$ \\
\hline
\end{tabular}

All test specimen preparation requirements specified in Section B.3.1 are completed. Authorization is granted to start the test.
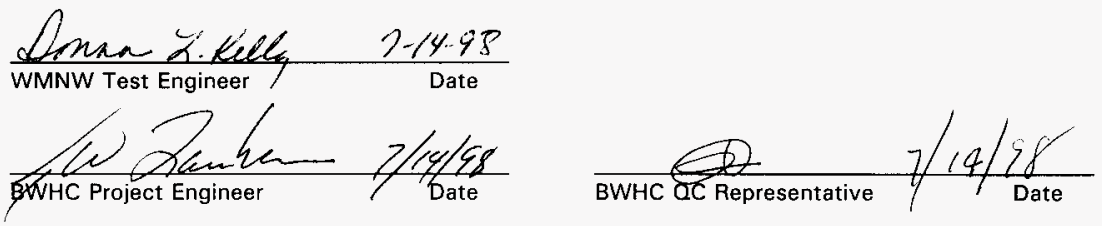

\section{B.3.2 Scrub Test Using Water Saturated Rags}

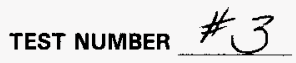

This test consists of subjecting each test specimen to a vigorous scrubbing using water saturated rags for a period of at least 5 minutes. After the test, the closure caps will be removed and the inside of each test specimen will be examined for water. The detailed procedure is as follows.

1. Place a test specimen in an appropriate holder. Saturate several rags with water and vigorously scrub the test specimen seal area for at least 5 minutes. Repeat the test for the other two test specimens. Record the following: 
HNF-3099 Rev. 0

HNF-2945. Rev. 0

OFFICHA GM

Test Specimen Number: $\quad(-P P / 2$

Start Time:

$10: 11: 33$

End Time:

$10: 16: 34$

Test Specimen Number:

Start Time:

End Time:

Test Specimen Number:

Start Time:

End Time:

2. After the test is completed, towel dry the test specimens to remove any visible moisture on the external surfaces. Pay particular attention to the seal area to ensure all moisture is removed.

3. Remove the closure cap from each test specimen. Record the breakaway torque value below for each test specimen as appropriate.

\begin{tabular}{|c|c|c|}
\hline & TEST SPECIMEN NUMBER & BREAKAWAY TOROUE VALUE \\
\hline & C-PP10 & \\
\hline & C-PP11 & \\
\hline Test $\# 3$ & C-PP12 & set (a) 50 buate (a) 25 \\
\hline
\end{tabular}

4. Visually examine the interior of each test specimen for water. If needed, use a black light. Use the table below to note any moisture detection to the seal area, gasket, threads, and inside the test specimen. Use the table below to note any galling of the threads or seal. In addition, record any additional information as needed for documentation purposes.

\begin{tabular}{|c|c|c|c|c|c|c|c|}
\hline \multirow{2}{*}{$\begin{array}{c}\text { TEST SPECIMEN } \\
\text { NUMBER }\end{array}$} & \multicolumn{4}{c|}{ MOISTURE } & \multicolumn{2}{c|}{ GALING } \\
\cline { 2 - 8 } & SEAL & GASKET & THREADS & INSIDE & THREADS & SEAL \\
\hline C-PP10 & & & & & & \\
\hline C-PP11 & & & & & & \\
\hline C-PP12 & $y$ & $y$ & $Y$ & $N$ & $N$ & $N$ \\
\cline { 2 - 8 }
\end{tabular}


4. Install the closure cap and seal on each test specimen. Ensure that the ideptification marking of the lid mates with the identification marking of the body.

On gne test specimen use a BWHC fabricated seal; on the other two test specimens use EWHC procured seals. Using the BWHC provided spanner, torque each closure cap to $25 \mathrm{ft}$-lbs. Record torque wrench calibration information, test specimen torque lelues, and type of seal below.

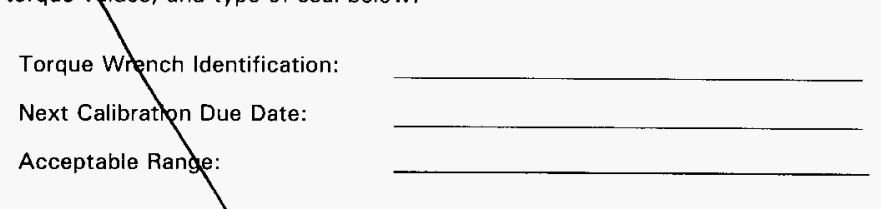

5. If needed, clean the external surfach of the test specimens.

All test specimen preparation requirements spedified in Section B.4.1 are completed. Authorization is granted to start the test.

\begin{tabular}{lc}
\hline WMNW Test Engineer & Date \\
\hline BWHC Project Engineer & Date
\end{tabular}

\section{B.4.2 Water Scrub Test Using Dampened Rag}

TEST NUMBER

This test consists of subjecting each test specimen to a vigorous scrubbing using water dampened rags for a period of at least 5 minutes. After the test, the closure chps will be removed and the inside of each test specimen will be examined for water. The detailed procedure is as follows.

1. Place a test specimen in an appropriate holder. Dampen several rags with water and vigorously scrub the test specimen seal area for at least 5 minutes. Repeat the test for the other two test specimens. Record the following: 
Tast Specimen Number:

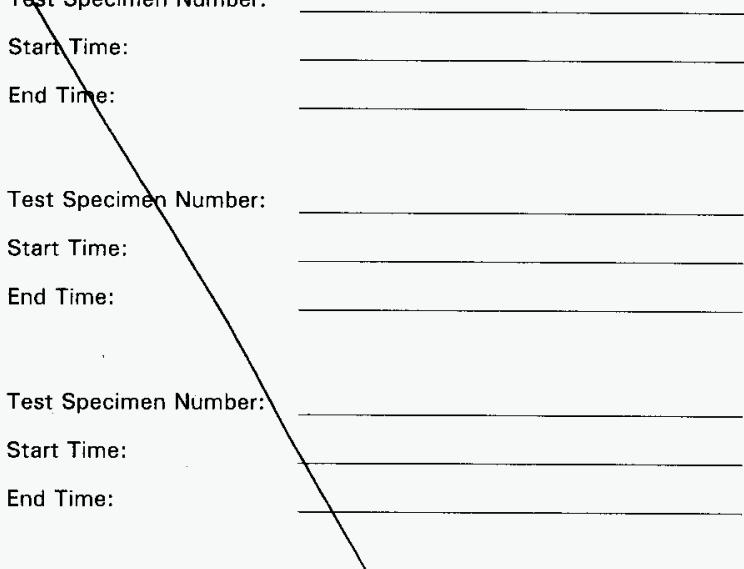

2. After the test is completed, towel dyy the test specimens to remove any visible moisture on the external surfaces. Pay particular attention to the seal area to ensure all moisture is removed.

3. Remove the closure cap from each test specimen. Record the breakaway torque value below for each test specimen as appropriate.

\begin{tabular}{|c|c|}
\hline TEST SPECIMEN NUMBER & BREAKAWAY TORQUE VALUE \\
\hline C-PP10 & \\
\hline C-PP11 & \\
\hline C-PP12 & \\
\hline
\end{tabular}

4. Visually examine the interior of each test specimen for water. If needed, use a black light. Use the table below to note any moisture detection to the seal area, gasket, threads, and inside the test specimen. Use the table bolow to note any galling of the threads and seal. In addition, record any additionah information as needed for documentation purposes.

needed for documentation purposes.
\begin{tabular}{|c|c|c|c|c|c|c|}
\hline $\begin{array}{c}\text { TEST SPECIMEN } \\
\text { NUMBER }\end{array}$ & \multicolumn{5}{|c|}{ MOISTURE } & \multicolumn{2}{c|}{ GALLYNG } \\
\hline & SEAL & GASKET & THREADS & INSIDE & THREADS & SEAL \\
\hline C-PP10 & & & & & & $\vdots$ \\
\hline C-PP11 & & & & & & \\
\hline C-PP12 & & & & & & \\
\hline
\end{tabular}


HNF-3099 Rev. 0

HANF 2045-ROV. 0

DFFCAA COPY

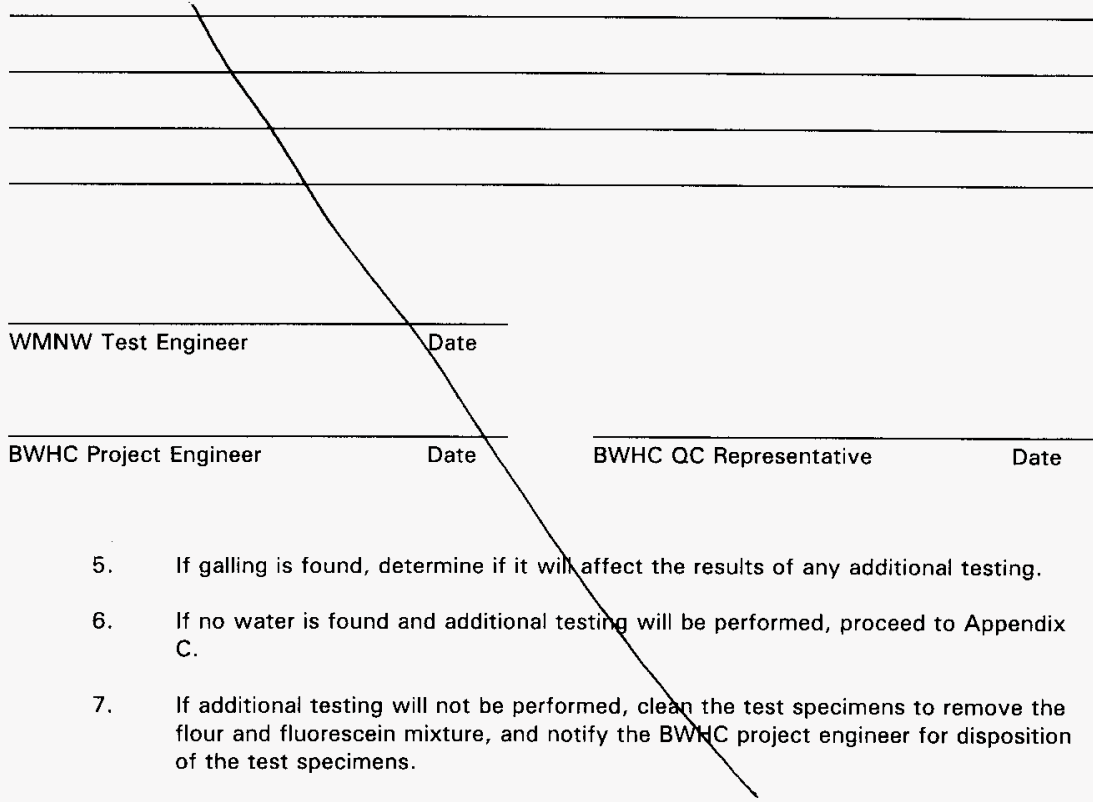


HNF-3099 Rev. 0

HNE-2946-Rov. 0

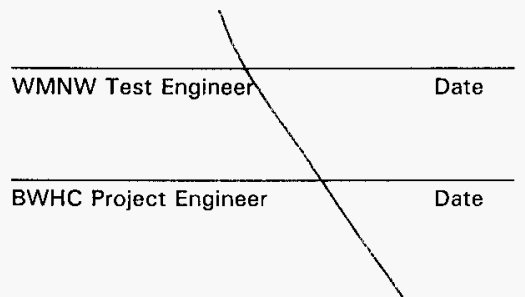

OFFICIAI SOFY

5. If galling is found, determine if it will affect the results of any additional testing.

6. If no water is found and additional testing will be performed, proceed to Section B.2 to continue with optional tests, or to Appendix $C$ for additional water immersion testing using a different torque value.

7. If additional testing will not be Rerformed, clean the test specimens to remove the flour and fluorescein mixture, and notify the BWHC project engineer for disposition of the test specimens.

\section{B.2 WATER SPRAY TESTS}

$$
\text { Test } 14 \text { (revered) }
$$

If water spray tests are desired, proceed with the following steps.

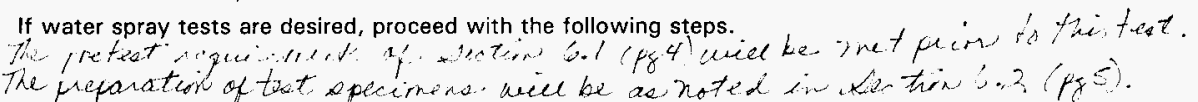

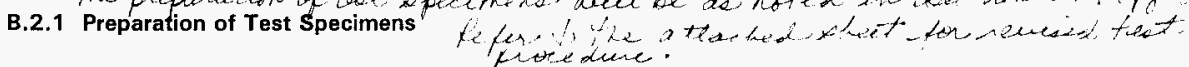

A mixture of and fluoresceln with be ptaced th eretr of the test units and the closure

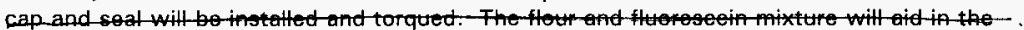
detection of any water that may loak in the test speeimens. The detailed preparation procedufes follow.

1. Ensure that each test specimen is clean and dry.

2. Determine if any galling found prior to conducting this test will affect the result of this test.

3. The flour-and fluorescein mixture used in the previous test may be used if adequate. If not adequate, remove the old flour flusesen mixture and prepere three new mixtures of $1 / 4$ - eup flour and $1 / 4$ tep fluorescein. Place one mixture into each test spocimen.

NOFE: Caution should be used to ensure that non of the mixture comes in contact with the test specimen outer surface or closure threads.

4.-Instell the closure cap and seal on each tost specimen. Ensure that the identifieation marking of the lid mates-with the identification marking of the body. On-one-test specimentuse a BWHC fabricated seat; on the other two test opecimens use BWHC procured seals. Using the BWHE provided spanner, torque each ctosure cap to 25-ft-bs. Record torque wrench elibation information, test ospomen torque values, and type of seal betow. 
HNF-3099 Rev. 0 OFFICIAI COFY

teat *4 (Heat / Watappray hat)

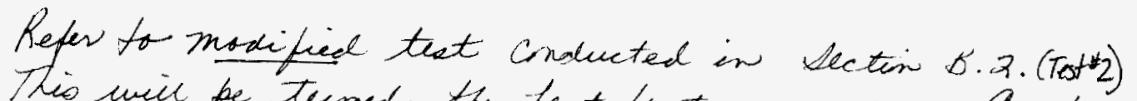

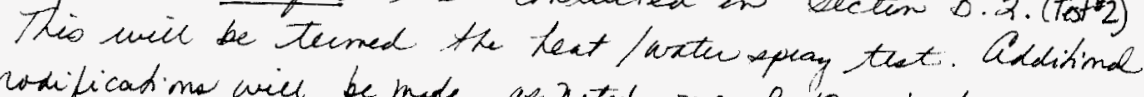

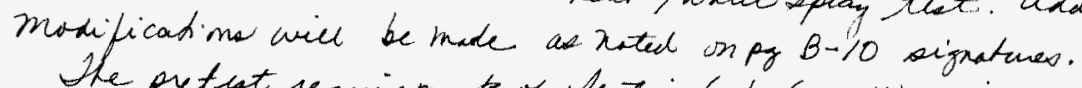
the pret at requiements of Lection 6.1 (page 4) aric be nut pios to this test.

The How t Geurscein mixture weil not he placed inise the teat opeciman.

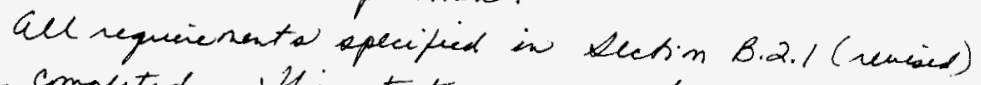
are crmplitud. Whio test apecimen the bur cleares and the lid + bodys repaliaked. Cuttanization is pranted to casenble the test opecimen and stant the teat, per 324 Plogies bugr, Bw ble.

Lhara 2 kele 214198

WMNW Thet Enje. Jate

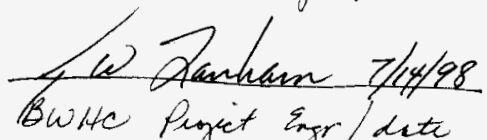

Bwitc Pugeit ingr/dite

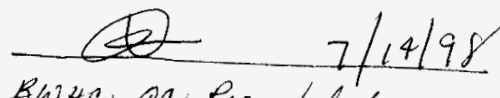

BWHC aC Re. / date.

Heat I Water Lpeay dest

$20 x+4$

This test will be performed arita, the

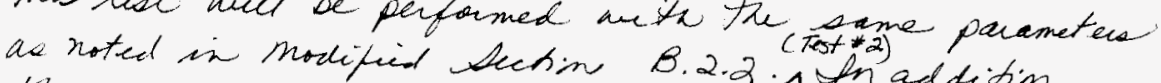

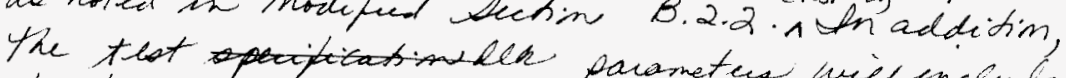
tie folloning ad dilional modificatsino.

(1) Tist apecimen wiel here cleaned cap a body interface.

(2) Tet opecinen wiel wt include a gashet.

(3) Tot epecimen miel be filed with heated guanty coystale untid appery. $25-80 \%$ quel. 
HNF-3099 Rev ODEFICAAI COFY

Teat \#4

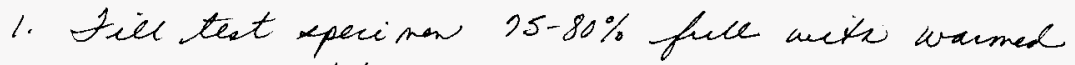
quartz crystato.

2. Heat teat Crntaina to apperimately $280^{\circ} \mathrm{C}\left(392^{\circ} \mathrm{F}\right)$ and remove firm oven. (ake closene cap wiel not be heated.) Recond temperatiue in taba below.

3. Srotull clascues cap onto test specimen. Whew twot enit reaches uppexirately- $100^{\circ} \mathrm{C}\left(212^{\circ} \mathrm{F}\right)$, torque closue cap to 25 ft lie. Recoux the torgue urmen calibuation infamatirn, feet specitrentione arelues, below.

Torque urench identification: $545-88-01-202 \sin 6064$ hext Calibuation due date: $\quad 2.27 .99$

Acuptrule range:

$$
+1-4 \%
$$

Test specimen $: \quad c-p \rho / 0$

Type of seal installad

Heated containe temp:

none

mitiel closure cap tonge balue: N/A (thand tiget) corled trat epec. temp: $182^{\circ} \mathrm{F}$

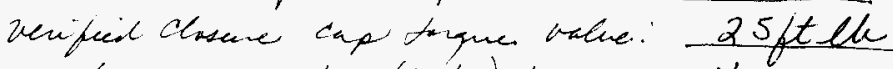

re-torgue reg't $(Y / N)$ :

No

4. If to. Sertin B.2.2 (ouigiaftext tar), step *1. the $1 /$ will now become Step $\$ 5$. Proced with tisterin.

A-44 
HNF-3099 Rev. 0

HNE-2945 ReV. O-

DEFICIA ORIF

Torque Wrench Identification:

Next Calibration Due Date:

Acceptable Range:

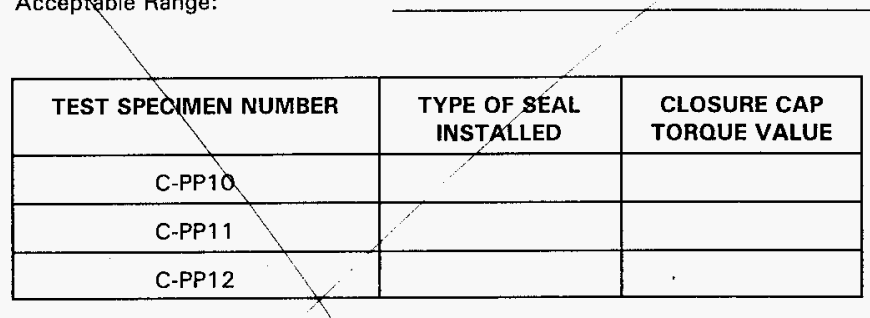

5. If needed, clean the external surface of the test specimens.

All test specimen preparation requirements spàcified in Section B.2.1 are completed.

Authorization is granted to start the test.
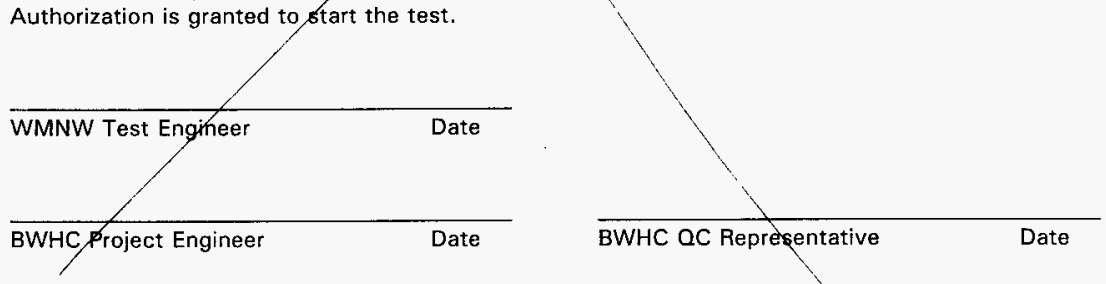

B.2.2 Water Spray Test

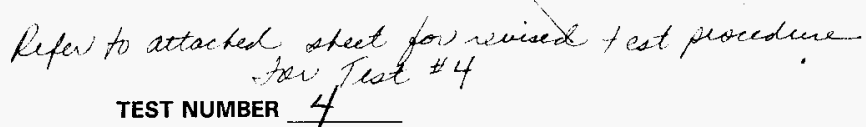

The water spray test consists of spraying water with a head of 4 feet an tho'seal area of the containar for two periods of at least 2 minutes each, After the test, the clogure caps will be removed and the inside of each test specimen will be examined for water. In addition, the threads and seats will be inspected for galling. The getailed procedure fotrows.

5. 7 . Place the three test specimens in an appropriate holder. Rig a container filled with water and equipped with a spigot in a position approximately 4 feet higher that the elevation of the top of the test specimens. Attach a 3/8-inch diameter tygon tube to the container spigot. Allow the water to gravity feed down the tube and spray the seal areas of the test specimens for a period of 2 minutes. The water container height is measured from the bottom of the water container to the upper most surface of the test specimens. At the end of the first period, refill the water container and repeat the spray test for another period of at least 2 minutes. Record the following: 
HNF-3099 Rev. 0

HNF-2945_Reve

C-m ral OCH

Period 1

Water Container Height:

Start Time:

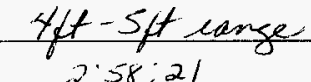

End Time:

$2: 58: 21$

$3: 01.22$

Period 2

Water Container Height:

Start Time:

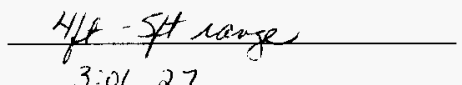

End Time:

3.01 .27

$3: 03: 28$

6. 2. After the test is completed, towel dry the test specimens to remove any visible moisture on the external surfaces. Pay particular attention to the seal area to ensure all moisture is removed.

2. 3 . Remove the closure cap from each test specimen. Record the breakaway torque value below for each test specimen as appropriate.

\begin{tabular}{|c|c|c|}
\hline \multirow{4}{*}{ Test $* 4-$} & TEST SPECIMEN NUMBER & BREAKAWAY TORQUE VALUE \\
\hline & C-PP10 & tat@50-luoke@2i \\
\hline & C-PP11 & \\
\hline & C-PP12 & \\
\hline
\end{tabular}

3. A. Visually examine the interior of each test specimen for water. If needed, use a black light. Use the table below to note any moisture detection to the seal area, gasket, threads, and inside the test specimen. Use the table below to note any galling of the threads or seal. In addition, record any additional information as needed for documentation purposes.

\begin{tabular}{|c|c|c|c|c|c|c|}
\hline \multirow{2}{*}{$\begin{array}{c}\text { TEST SPECIMEN } \\
\text { NUMBER }\end{array}$} & \multicolumn{4}{|c|}{ MOISTURE } & \multicolumn{2}{c|}{ GALLING } \\
\cline { 2 - 8 } & SEAL & GASKET & THREADS & INSIDE & THREADS & SEAL \\
\hline C-PP10 & $Y$ & $N A$ & $Y$ & $N$ & $N$ & $N$ \\
\hline C-PP11 & & & & & & \\
\hline C-PP12 & & & & & & \\
\hline
\end{tabular}


HNF-3099 Rev. 0

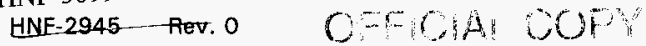

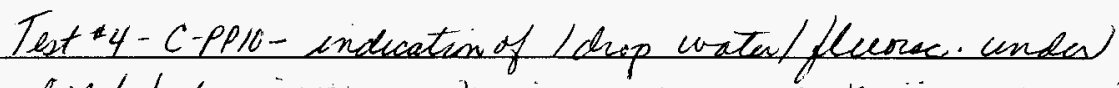

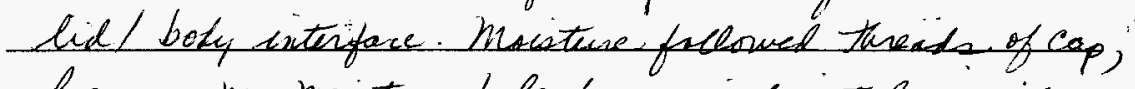

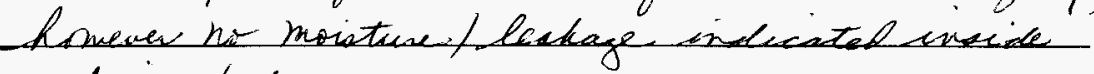
contriner body.
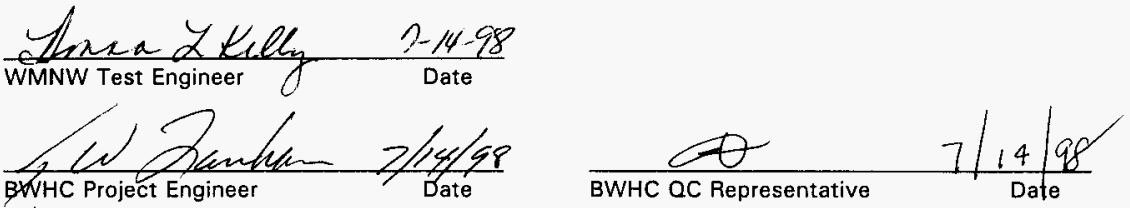

1. מ6. If galling is found, determine if it will affect the results of any additional testing.

12. 6. If no water is found and additional testing will be performed, proceed to Section B.3 for additional optional tests.

11. 7 . If additional testing will not be performed, clean the test specimens to remove the flour and fluorescein mixture, and notify the BWHC project engineer for disposition of the test specimens.

\section{B.3 SCRUB TEST USING WATER SATURATED RAGS}

\section{B.3.1 Preparation $d$ Test Specimens}

A mixture of floc and fluorescein will be placed in each of the test units and the closure cap and seal will be installed and torqued. The flour and fluorescein mixture will aid in the detection of any water that pay leak into the test specimens. The detailed preparation procedures follow.

1. Ensure that each tes specimen is clean and dry.

2. Determine if any galling keund prior to conducting this test will affect the result of this test.

3. The flour and fluorescein mixture used in the previous test may be used if adequate. If not adequate, remove the old Kour and fluorescein mixture and prepare three new mixtures of $1 / 4$ cup flour and $1 / 4$ tsp fluorescein. Place one mixture into each test specimen.

NOTE: Caution should be used to ensure that none of the mixture comes in contact with the test specimen outer surface or closure threads. 
If water in-leakage is detected the Inner Containers will be cleaned out, the closure cap on each on each Innter Container will be torqued to $25 \mathrm{ft}$-lbs, and the Inner Containers will be subjected to an 2-hinute water wash from a hose attached to a water container that is 4 feet above the elevation the test is conducted at. If no leakage of water is detected, additional testing will not be required.

If water in-leakade is detected the Inner Containers will be cleaned out, the closure cap on each Inner Container will torqued to $25 \mathrm{ft}-\mathrm{lbs}$ and the containers will be subjected to a vigorous scrub using water saturatedyags for a period of 5 minutes. If no leakage of water is detected, additional testing will not be required.

If water in-leakage is detacted the Inner Containers will be cleaned out, the closure cap on each Inner Container will be torqued to $25 \mathrm{ft}-\mathrm{lbs}$ and the containers will be subjected to a vigorous 5 -minute scrub using dampened rag if no leakage of water is detected, additional testing will not be required.

If water in-leakage is detected, BVHC Cesium Legacy project management will be consulted to determine path forward. Opthenal test procedures provided in Appendix B. If BWHC Cesium Legacy project management determirtes that a higher torque value is to be tested, follow the additional water immersion test procedure provided in Appendix C.

A copy of the test results will be forwarded to BWHC Cesium Legacy cognizant engineer upon successful completion of the test procedure.

\subsection{PRETEST REQUIREMENTS lest 5 and lest 6}

The following items will be verified prior to starting the test.

1. The lid and body of each test specimen shall be permanently and uniquely marked to ensure traceability of the test specimen throughout the test. The identification marking of the lid for each test specimen shall match the identification marking of the test specimen body.

2. The BWHC material transfer form (included in Appendix A) shall be completed, and a copy of this form shall be provided to the BWHC project engineer or designee by the recipient of the test specimens.

3. Each test specimen shall be fabricated to drawing H-3-307832.

4. Test apparatus is ready and instruments are calibrated.

All requirements specified in Section 6.1 are completed. Authorization is granted to assemble the test specimens and start the test.
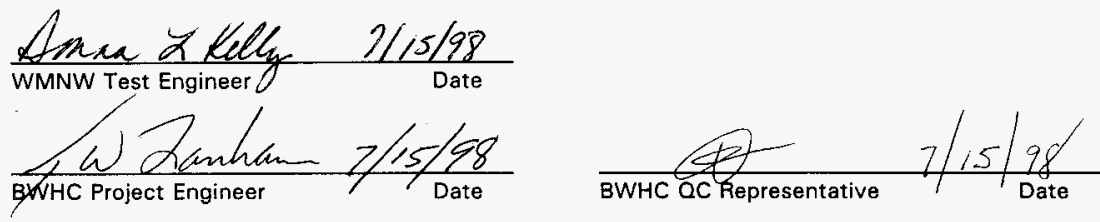
HNF-3099 Rev. 0

HNE-2945 - Rer. 0

\subsection{PREPARATION OF TEST SPECIMENS}

1. Ensure that each test specimen is clean and dry.

2. Lid and body interface were repolished prion tic condecting this test

All test specimen preparation requirements specified in Section 6.2 are completed.

Authorization is granted to start the test.

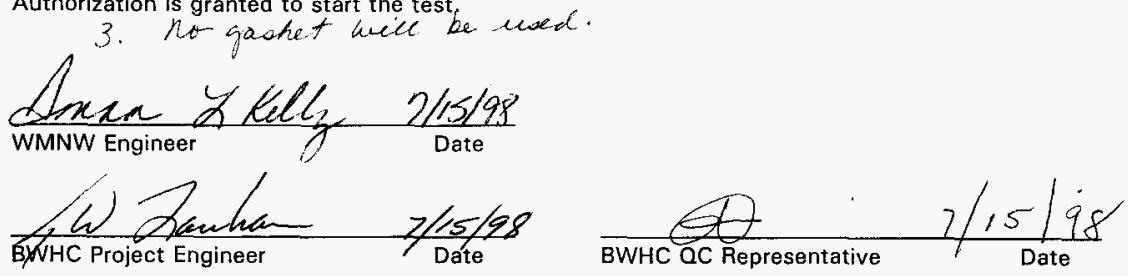

\subsection{HEAT/WATER IMMERSION TEST}

$$
\text { TEST NUMBERT } 5 \text { and. } 6
$$

The heat/water immersion test consists of heating the test specimens to approximately $200^{\circ} \mathrm{C}\left(392^{\circ} \mathrm{F}\right)$, placing the closure cap onto each Container and torquing the cap to $25 \mathrm{ft}-\mathrm{lbs}$. The test specimen will be free-air cooled to approximately $100^{\circ} \mathrm{C}\left(212^{\circ} \mathrm{F}\right)$ and the closure cap torque reverified to $25 \mathrm{ft}$-lbs. The specimen will then be placed into a pool of water that contains a leakdetection agent (fluorescein). The test specimens will be placed into the water to a depth of $8.1 \mathrm{ft}$ $(+0.5 /-0 \mathrm{ft})$ for a period of at least 5 minutes. After the test, the closure cap will be removed and the inside of the test specimen will be examined for in-leakage of fluorescein water. In addition. the threads and seals will be inspected for galling. The detailed procedure follows.

y and salt

2. 7 . Heat the Container to approximately $200^{\circ} \mathrm{C}\left(392^{\circ} \mathrm{F}\right)$ and remove from oven. (The closure cap will not be heated.) Record the temperature in the table below.

3. 2. Install the closure cap pothstrect seat on the test specimen. Using the BWHC provided spanner, torque the closure cap to $25 \mathrm{ft}$-lbs. Record torque wrench calibration information, test specimen torque values, and type of seal below.

Torque Wrench Identification: $\quad 545-88-0 /-2025 / 106064$ Next Calibration Due Date:

Acceptable Range:

$\frac{2-27-99}{+1-4 \%}$

1. Fiel test specimens with coace eact to approximatels 75-80\% full. Xote-no gashet wiel be used.

wote. Test specimen $c-p p l \lambda$ will be filled with salt only tipped with

Test specimen $c$ - ppll will be filled with salt
approximatelug i Table spoon of bahing flour. 


\begin{tabular}{|c|c|c|c|c|c|c|}
\hline $\begin{array}{c}\text { TEST } \\
\text { SPECIMEN } \\
\text { NUMBER }\end{array}$ & $\begin{array}{l}\text { TYPE OF SEAL } \\
\text { INSTALLED }\end{array}$ & $\begin{array}{l}\text { HEATED } \\
\text { CONTAINER } \\
\text { TEMP. }\end{array}$ & $\begin{array}{l}\text { INITIAL } \\
\text { CLOSURE } \\
\text { CAP } \\
\text { TORQUE } \\
\text { VALUE }\end{array}$ & $\begin{array}{l}\text { COOLED } \\
\text { TEST } \\
\text { SPEC. } \\
\text { TEMP. }\end{array}$ & $\begin{array}{c}\text { VERIFIED } \\
\text { CLOSURE } \\
\text { CAP } \\
\text { TORQUE } \\
\text { VALUE }\end{array}$ & $\begin{array}{c}\text { RE- } \\
\text { TOROUE } \\
\text { REQ'D } \\
(Y / N)\end{array}$ \\
\hline \multicolumn{7}{|l|}{ C-PP1O } \\
\hline C-PP11 & nove & $201.5^{\circ} \mathrm{C}$ & $25 / t-\mu h$ & $210^{\circ} \mathrm{F}$ & $25 \mu t h$ & $y$ \\
\hline C-PP12 & none & $201 y^{\circ} \mathrm{C}$ & $25 \mu-26$ & $2 / 2^{\circ} \mathrm{F}$ & $25 \mu \cdot t h$ & $y$ \\
\hline
\end{tabular}

4. 7 . Free-air cool the test specimen to approximately $100^{\circ} \mathrm{C}\left(212^{\circ} \mathrm{F}\right)$. Record the temperature in the table above.

5. A. Verify that the torque on the closure cap is $25 \mathrm{ft}$-lbs. Re-torque to $25 \mathrm{ft}$-lbs if needed. Record the verified closure cap torque value in the table above, and indicate if re-torquing was required.

6. 5. Place the test specimen into an appropriate holder and lower the specimen into the pool of fluorescent water to a depth of $8.1 \mathrm{ft}(+0.5,-0 \mathrm{ft}$ ) (use 8 feet, 8 inches). The immersion depth is measured from the top of the water to the upper most surface of the test specimen. Hold the test specimen at the prescribed depth for at least 5 minutes. Remove the test specimen. This test will be conducted on all three test specimens. Record the following:

$\begin{array}{ll}\text { Test Specimen: } & \frac{C-P P / 2}{8 / 4-8 \text { in }} \\ \text { Immersion Depth: } & \frac{8 f 18.54}{\text { Start Time: }} \\ \text { End Time: } & -123: 55\end{array}$

Test Specimen:

$\frac{c-\rho \rho / 1}{8 f t-8 \operatorname{cin}}$

Immersion Depth:

Start Time:

$2: 12 \cdot 30$

End Time:

$$
\text { 2.1731 }
$$

Test Specimen:

Immersion Depth:

Start Time:

End Time: 
HNF-3099 Rev. 0

HNF-2945 Rov. 0

OF,

7. 6. After the test is completed, towel dry the test specimen to remove any visible moisture on the external surfaces. Pay particular attention to the seal area to ensure all moisture is removed.

8. 77. Remove the closure cap from each test specimen. Record the breakaway torque value below for each test specimen as appropriate.

\begin{tabular}{|c|c|}
\hline TEST SPECIMEN NUMBER & BREAKAWAY TORQUE VALUE \\
\hline C-PP10 & \\
\hline C-PP11 & setQ95-broke@60 \\
\hline C-PP12 & set@9i.broke@ $\mathscr{Q}$ \\
\hline
\end{tabular}

9. \&. Visually examine the interior of each test specimen for in-leakage of fluorescent water. If needed, use a black light. Use the table below to note any fluorescein detection to the seal area, gasket, threads, and inside the test specimen. Use the table below to note any gualling of the threads or sealing surface. In addition, record any additional information as needed for documentation purposes.

\begin{tabular}{|c|c|c|c|c|c|c|}
\hline \multirow{2}{*}{$\begin{array}{c}\text { TEST SPECIMEN } \\
\text { NUMBER }\end{array}$} & \multicolumn{4}{|c|}{ FLUORESCEIN/MOISTURE } & \multicolumn{2}{c|}{ GALLING } \\
\cline { 2 - 8 } & SEAL & GASKET & THREADS & INSIDE & THREADS & SEAL \\
\hline C-PP10 & & & & & & \\
\hline C-PP11 & $y$ & $N A$ & $Y$ & $Y$ & $N$ & $N$ \\
\hline C-PP12 & $y$ & $N A$ & $Y$ & $N(?)$ & $N * *$ & $N *$ \\
\hline
\end{tabular}

Test \#5 (C-PP/2): moisture unduside of cap rabout 3/4 doun on cap theada. Inside was questionable + some comparisons perfomel. See notes on backside of this sheet. Teat 6 (c-PPII): moisture indicated as noted in Table aloove. Approx. $1 / 4$ tears of of morsture present indide twaet along sides. Detected on Amua 2 .telly $\frac{\text { P.15-98 }}{\text { Date }}$
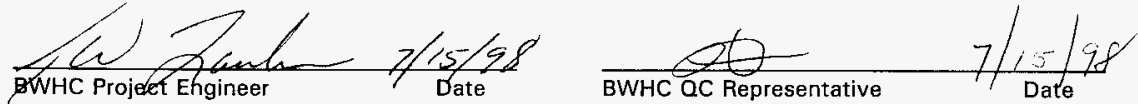
$n / 1598$

HNF-3099 Rev. 0

OFFICIAL COPY

$\operatorname{tes} x^{4} 5(c-p p l a)$ Hoto:

1. Checherd salt ceptala from test enict $\%$

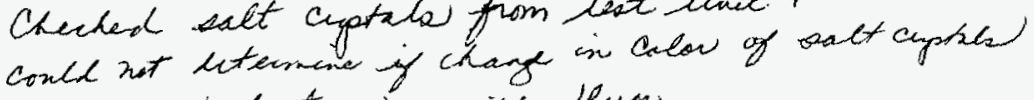
war due of hest os possipk fluse.

2. Cherhed heated solt mpotale + lowhed similar to solt ayptrila in $\# /$ aboves.

3. Cheched "Clean" unhented salt aupotale - pritisin color.

4. chected thatel salt ouptala form $4 /$ abouc and

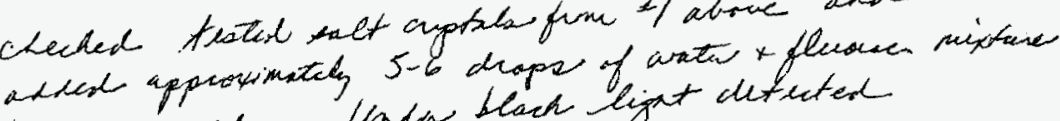

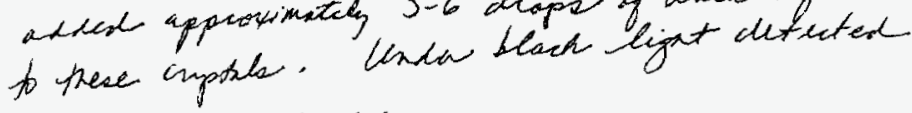
flusoo. immediatedy.

Aetermined that teat wiat c-ppia dix not chuer any in-leakage of watis and fluses.

$2 / 16 / 98$

* Test * 5 (C-PP/2) after tant unit was tranoferved to fracility for poliskig, Project enganew in ted galling of the hid and body did dccent.

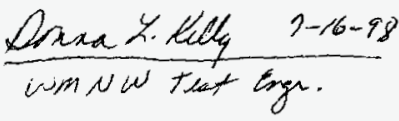

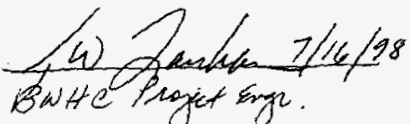

(2) $1 / 16 / 48$

butte ac bae

A- 52 


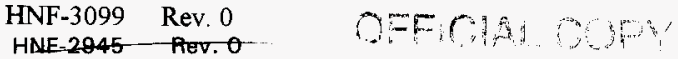

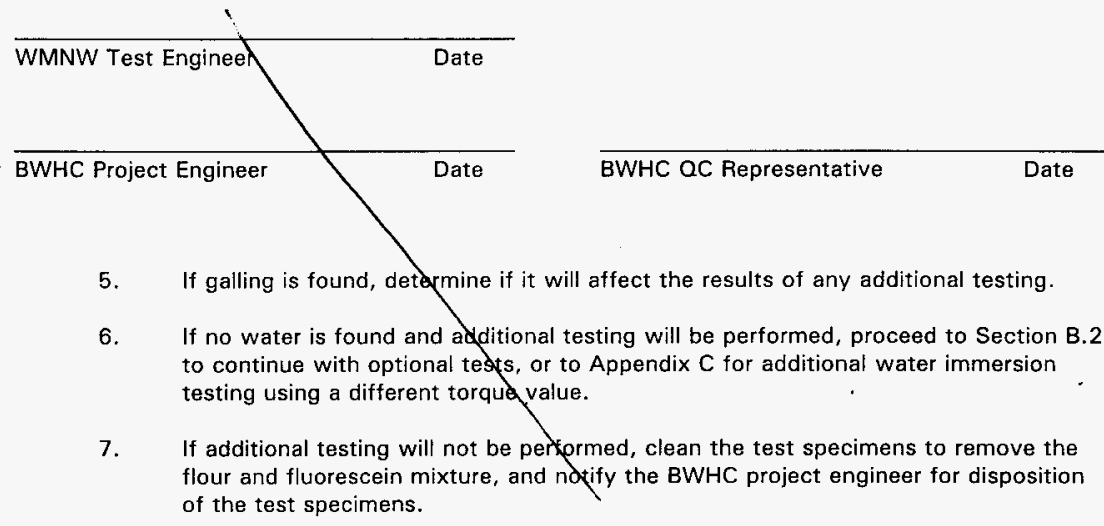

\section{B.2 WATER SPRAY TESTS}

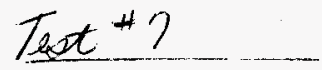

If water spray tests are desired, proceed with the following steps. wiel be met phin to

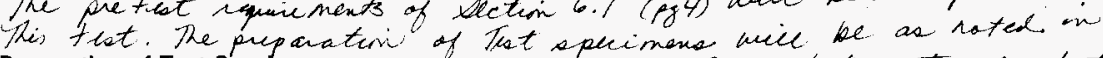
B.2.1 Preparation of Test Specimens dectims 6.2 ( $p, 5)$. Refer to the attached aheet for reviace foet purceduc.

A mixture of flotf and fluoresdein will be plased in each of the test units and the closure cap and seal will be instatled and torqued. The flour and fluorescein mixture will aid in the detection of any water that may leak into the test specimens. The detailed preparation procedures follow.

1. Ensure that each test specimen is clean and dry.

2. Determine if any galling found prior to conducting this test will affect the result of this test.

3. ...... The floup and fluorescein mixture used in the previous test may be used if adequate. If not adequate, remove the old flour and fturesente mixture and prepare theen mixtures of $\frac{1 / 4}{4}$ cup flour and $1 / 4 / 4$ tsp fluorescein. Place one mlxture thro each test specimert.

NOTE: Caution should bo used to ensure that none of the mixture comes in contact with the testspecimen outer surface or closure threads.

4. Instatt the closure en and seal on each test spectmen. Ensure that the identification marktng of the lid mates with the icentification marking of the body. On ono-test specimen use a BWHC fabricated seal; on the other two test specimens use BWHC procured seals. Using the BWHC proved opere torte cap to 25-ft-lbs.- frecord torque wrenoh calibration information, tos ecimen torque values, and type of seal below. 
HNF-3099 Rev. 0 OFFICIAL COPY

Text $* 7$

Hest / Gate Spray Teat

The Heat / Water spay test will be enounced to verify the results of Teat 4 .

The text specimens have bee cleaned o polished prow to conducting this teat.

The pretest requirements of Action 6.1 (page 4) -have been met pion to this test.

Authorization is granted to somber the test specimens and strut the teat, pa 324 Projects Inge, BWHC.

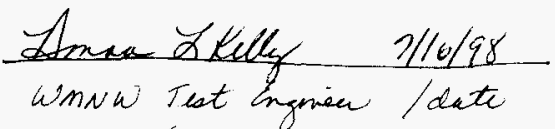

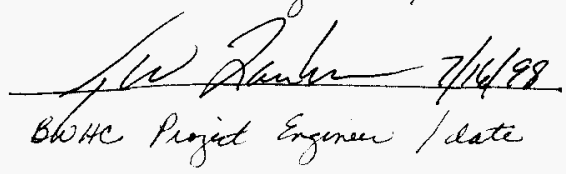

Heat / Wats Spray Test

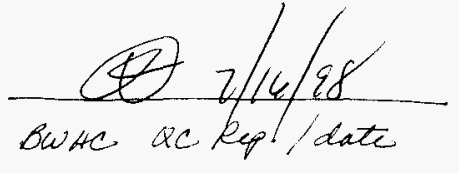

Lest $\# ?$

This tint will be performed with the same. parameters as noted in Test \#4. ha addition; the test parameters will include the following modifications:

(1). Nest specimen o will have cleaned body $x$ cap interface.

(2) Lest specimens will nt include a gasket.

(3) That specimens will be filled with Core costal salt until approx. $75-80 \%$ fuel.

A-55 
$9 \varsigma-V$ S. Sost using

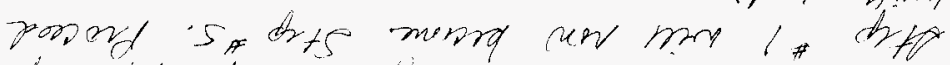

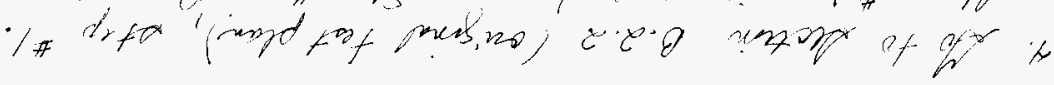

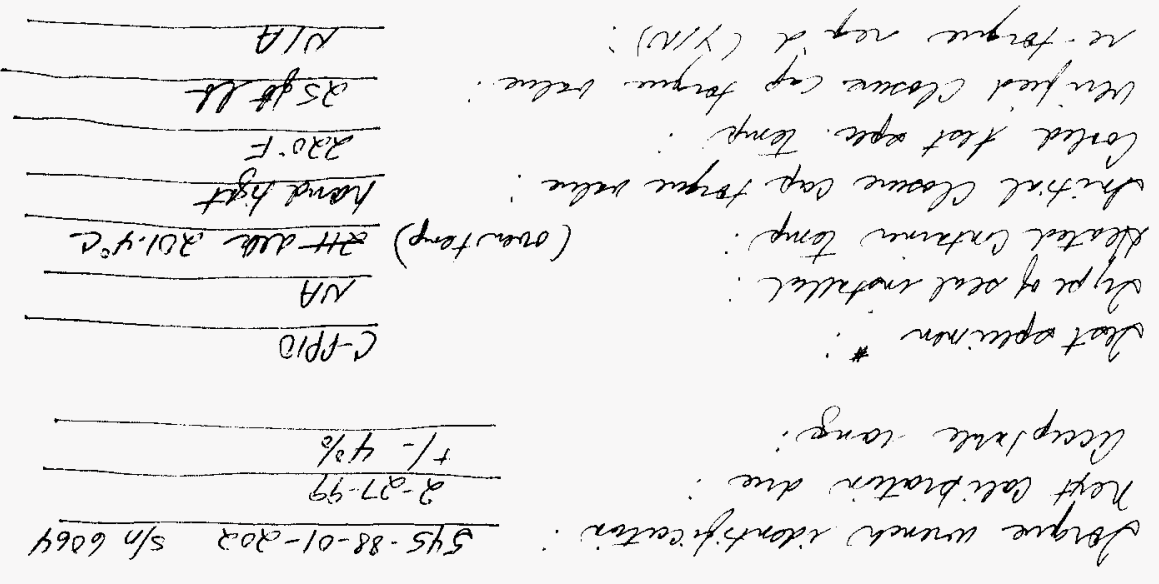

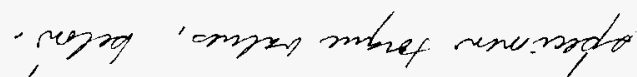

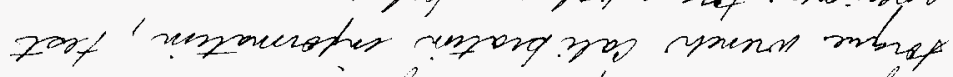

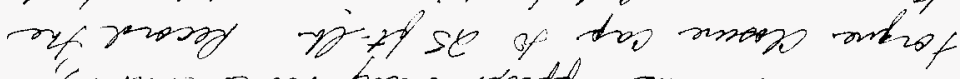

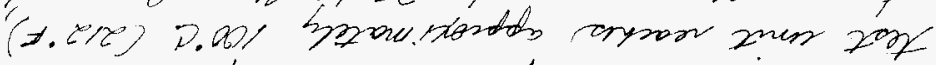

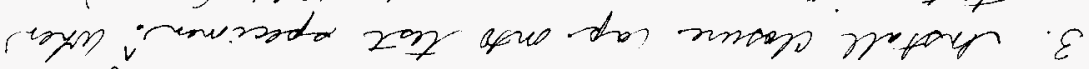
rengin

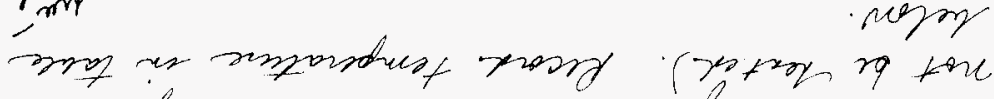

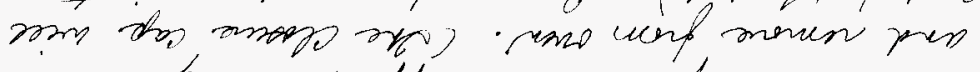

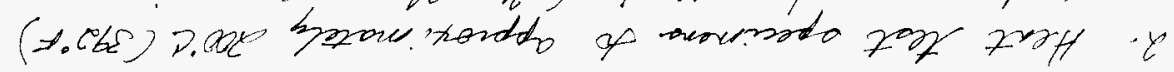

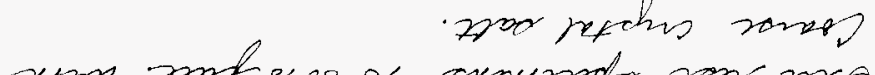

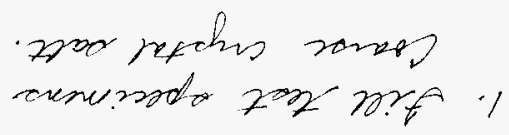


HNF-3099 Rev. 0 OFF!rif

Torque Wrench Identification:

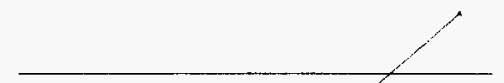

Next Calibration Due Date:

Acceptable Range:

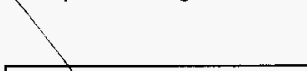

\begin{tabular}{|c|c|c|}
\hline TEST SPECIMEN NUMBER & $\begin{array}{c}\text { TYPE OF SEAL } \\
\text { INSTALLED }\end{array}$ & $\begin{array}{c}\text { CLOSURE CAP } \\
\text { TOROUE VALUE }\end{array}$ \\
\hline C-PP10 & & \\
\hline C-RP11 & & \\
\hline C-PP12 & &. \\
\hline
\end{tabular}

5. If needed, clean the exterpal surface of the test specimens.

All test specimen preparatiøn requirengents specified in Section B.2.1 are completed. Authorization is granted to start the test.

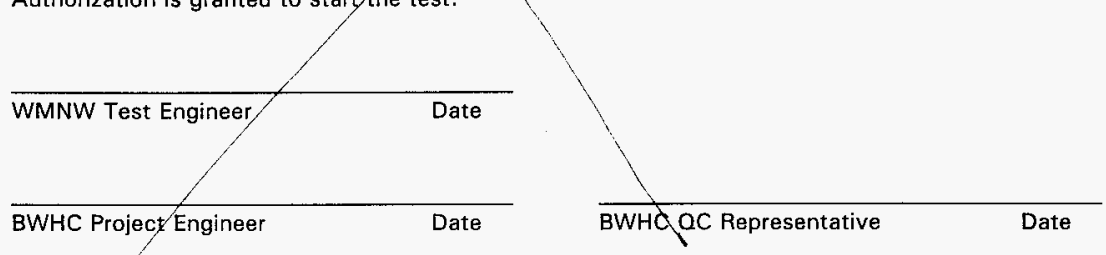

B.2.2 Water Spray Test

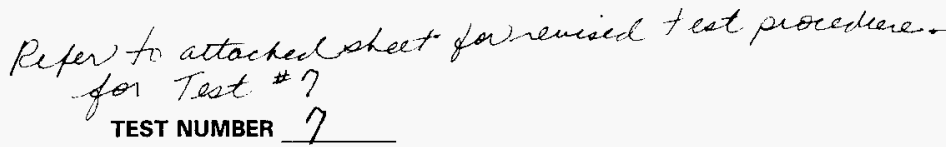

The wayer spray test consists of spraying water with a head of 4 feet en the geal area of the container for two periods of at least 2 minutes each. After the test, the closure caps will be removed and the inside of each tes specimen withe examined for water. In addition, the threads and seals will be inspected fargalling. The detailed procedure follows.

5. $x$. Place the three test specimens in an appropriate holder. Rig a container filled with water and equipped with a spigot in a position approximately 4 feet higher that the elevation of the top of the test specimens. Attach a 3/8-inch diameter tygon tube to the container spigot. Allow the water to gravity feed down the tube and spray the seal areas of the test specimens for a period of 2 minutes. The water container height is measured from the bottom of the water container to the upper most surface of the test specimens. At the end of the first period, refill the water container and repeat the spray test for another period of at least 2 minutes. Record the following: 
HNF-3099 Rev. 0

HNE-2945-REV. 0

\section{Period 1}

$\begin{array}{ll}\text { Water Container Height: } & 4 / 4 \\ \text { Start Time: } & \frac{10: 18 \cdot 15}{10 \cdot 20: 30} \\ \text { End Time: } & -10\end{array}$

Period 2

Water Container Height:

$\frac{4.4 t}{10 \cdot 20 \cdot 34}$

6. 2.

After the test is completed, towel dry the test specimens to remove any visible moisture on the external surfaces. Pay particular attention to the seal area to ensure all moisture is removed.

1. R. Remove the closure cap from each test specimen. Record the breakaway torque value below for each test specimen as appropriate.

\begin{tabular}{|c|c|c|}
\hline \multirow{4}{*}{$T_{8}+7$} & TEST SPECIMEN NUMBER & BREAKAWAY TORQUE VALUE \\
\hline & C-PP10 & set@90-broke 069 \\
\hline & C-PP11 & \\
\hline & C-PP12 & \\
\hline
\end{tabular}

8. 4. Visually examine the interior of each test specimen for water. If needed, use a black light. Use the table below to note any moisture detection to the seal area, gasket, threads, and inside the test specimen. Use the table below to note any galling of the threads or seal. In addition, record any additional information as needed for documentation purposes.

\begin{tabular}{|c|c|c|c|c|c|c|c|}
\hline \multirow{2}{*}{$\begin{array}{c}\text { TEST SPECIMEN } \\
\text { NUMBER }\end{array}$} & \multicolumn{4}{|c|}{ MOISTURE } & \multicolumn{3}{c|}{ GALLING } \\
\cline { 2 - 8 } & SEAL & GASKET & THREADS & INSIDE & THREADS & SEAL \\
\hline C-PP10 & $Y$ & $N / A$ & $Y$ & $Y$ & $N$ & $Y$ \\
\hline C-PP11 & & & & & & \\
\hline C-PP12 & & & & & & \\
\hline
\end{tabular}


HNF-3099 Rev. 0

HNE-2946_-ATEV O

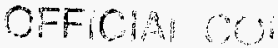

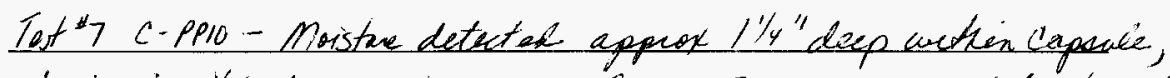

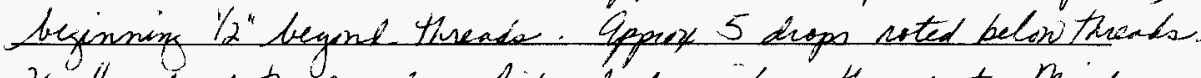

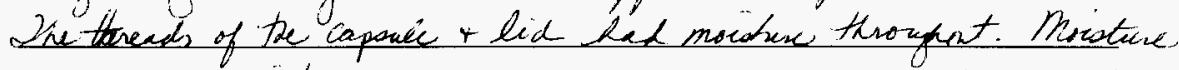

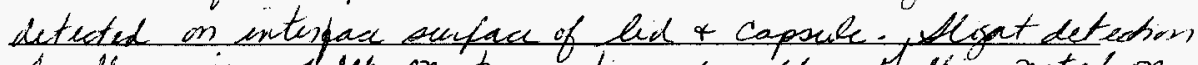

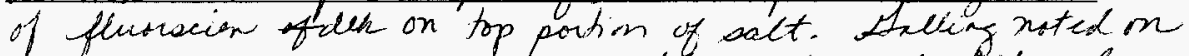

$\frac{\text { Laxa Xklly }}{\text { WMNW Test Engined }} \frac{2 / 16 / 98}{\text { Date }}$ maten purface of lid and dimtresen.
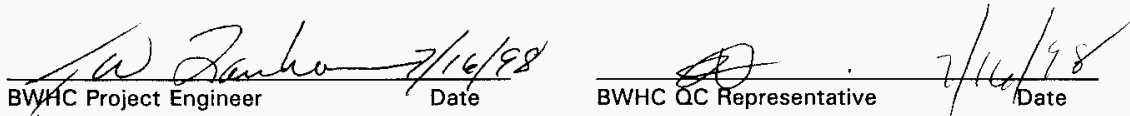

9. 5. If galling is found, determine if it will affect the results of any additional testing.

10. 6. If no water is found and additional testing will be performed, proceed to Section B.3 for additional optional tests.

11. 7. If additional testing will not be performed, clean the test specimens to remove the flour and fluorescein mixture, and notify the BWHC project engineer for disposition of the test specimens.

\section{hate.}

B.3 SCRUB TEST USING WATER SATURATED RAGS Test $* 8, \neq 9,10$

\section{B.3.1 Preparation of Test Specimens}

Pefer to attached atat's mateed treat/Lublest leeng

blew dxterater katis.

A mixture of flour and fluorescein will be placed in eachef the test units and the closure cap and seal will be installed and torqued. The flour and fluoresceitio mixture will aid in the detection of any water that may leak into the test spectonens. The detailed preparation procedures follow.

1. Ensure that each test specimen is clean and dry.

2. Determine if any galling found prior to conducting this test will affect the result of this test.

3. The flour and fluorescein mixture used in the previous test may be used if adequate. If thet adequate, remove the old flour and fluorascein mixture and prepare three new mixtures of $1 / 4$ cup flour and $y / s p$ fluorescein. Prace one mixture into each test specimen.

NOTE: Caution should be used to ensure that none of the mixture comes in contact with the test specimen outer surface or closure threads. 
DFFICIAI COPY

HNF-3099 Rev.

Test \#8, \$9,10 Heat/ Acub vest Using Water Saturatid Rage

The test specimens tave been cleaned + polished prion to condecting this test.

The pre-test requiriereats of slection 6.1 (page 4) have been net prien to this test.

Authorizatirn is granted to asonble the teat opecimens and sait he that, pew 324 Projicts Myr, BwHC.

Lerra Z- Kelly $?-16.98$

wonk toat Enge/date

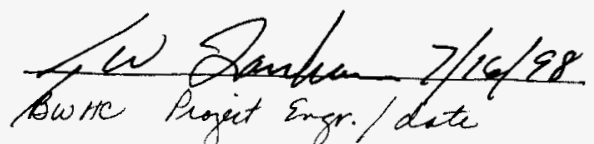

butre Proget Engr. I date

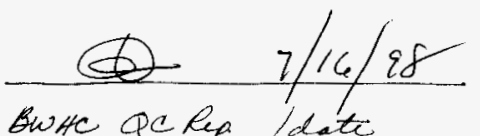

Buste achep /date

Heat I Acub West Hoing Water Aatuated Page

Lest $\# 8, \neq 9, * 10$

(1) Whe test specimens will tave cleared body + cap intefface, and be polisked.

(2) Dest opecimens miel not incluoce a gashet

(3) Det opecimene wier ie fieled with Coase salt until approx. $25-80 \%$ fuel.

(4) Any gacling roted during preverina teating stace be determined to not affect the nesits of additinal tiesting.

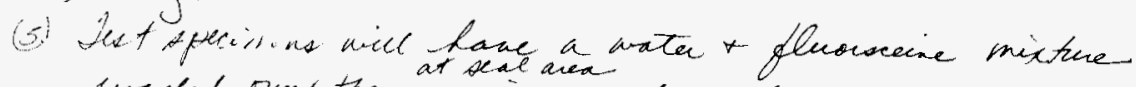
-washed over themin using a sherated rag.

(6) Reat specimene wiel be tonqued to 20 pt-lles instead of 25 ftellas.

A- 60 
HNF-3099 Rev. 0

Teat $\# 8, \# 9, \# 10$ OFFICIA COPY

1. Fill teat epecimens $35-80 \%$ full with crase enptal selt.

2. Heat teat epecinens to approximately $200^{\circ} \mathrm{C}\left(392^{\circ} \mathrm{F}\right)$ and remove firm oven. (the Closure cap will not be heated.) Recond temperature in table belin.

3. Srothel closure cap onti teat specimen. tree-ain cool. Whan test unit reaches approximatily $100^{\circ} \mathrm{C}\left(210^{\circ} \mathrm{F}\right)$ torgue the closure cap to $20 \mathrm{ft}$-lbs. Record the torque wreveh Calibration information, teat specimes. torme values, beloni:

Lorgue wrench identifecation: $\quad 545-88-01-202$ Stin 6064 hext calibuation due:

Aceptable range:

Het opecimen."

Mpe of seal inotzled.

Steated contriva timp: (oven) Anitial tougue value:

Corled tist spectemp.

Verified closure captorge behe. ki-torque reg'l $(Y, X)$ :

$$
\frac{2-27-99}{+1-4 \%}
$$

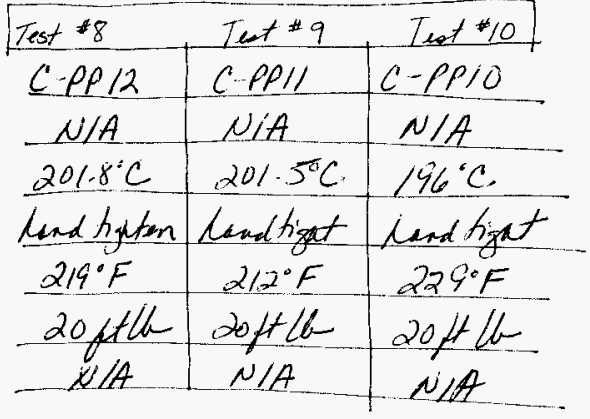

4. to to dectin B.3.2 (onignis text Plan). Hep $\$$; wiel now becme. Step $\# 5$. Proceed wita tedtig.

A-61 
4. Install the closure cap and seal on each test specimen. Ensure that the identification marking of the lid mates with the identification marking of the body.

- On one test-specimen us BWHC fabricated seat; on the other two test specimens use BWHC procured seals. Using the BWHC provided spanner, torgue each closure dap to $25 \mathrm{ft}$-lbs. Record torque wrench calibration information, test specimen tokque values, and type of seal below.

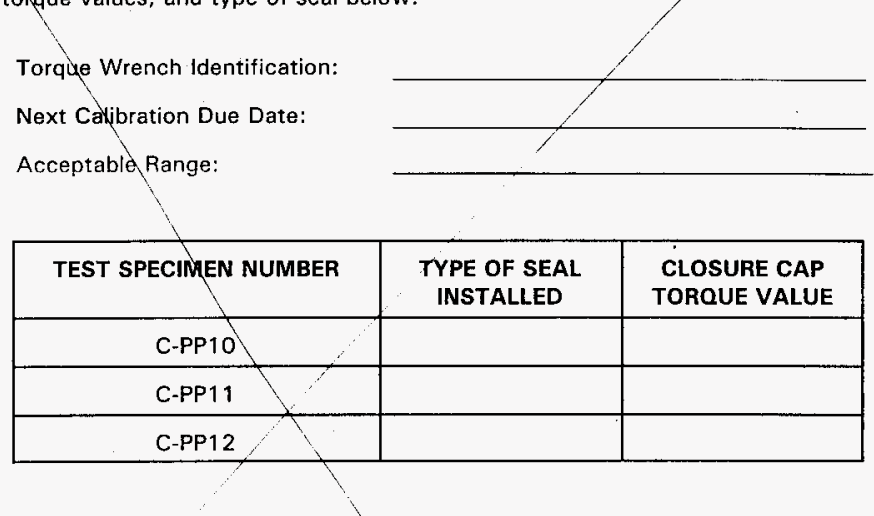

5. If needed, clean the external surface of the test specimens.

All test specimen preparation requirements specified in Section B.3.1 are completed. Authorization is granted to start the test.
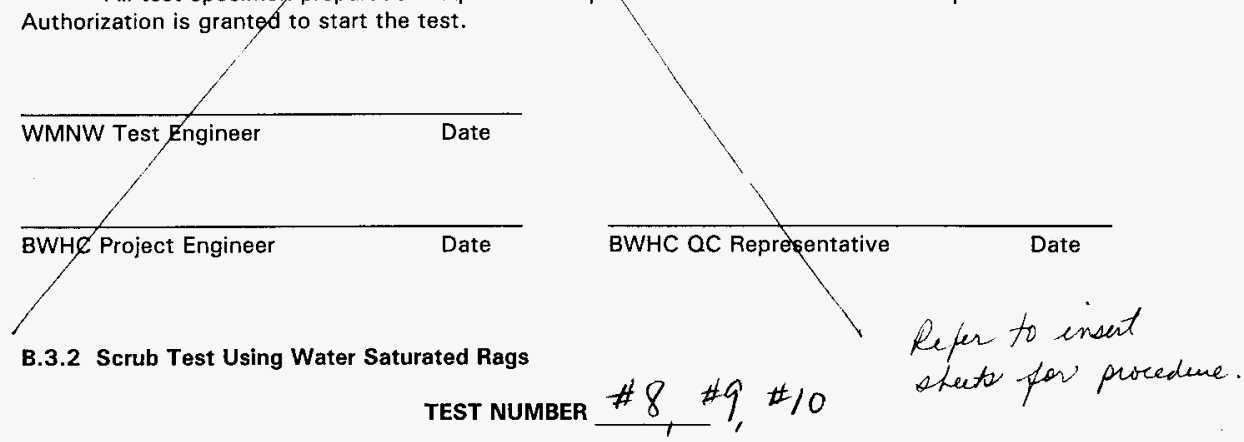

This test consists of subjecting each test specimen to a vigorous scrubbing using water saturated rags for a period of at least 5 minutes. After the test, the closure caps will be removed and the inside of each test specimen will be examined for water. The detailed procedure is as follows.

5. 1.

Place a test specimen in an appropriate holder. Saturate several rags with water and vigorously scrub the test specimen seal area for at least 5 minutes. Repeat the test for the other two test specimens. Record the following: 
HNF-3099 Rev. 0

HNE-2846-Rov, O.

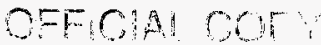

Test $\# 8$ Test Specimen Number:

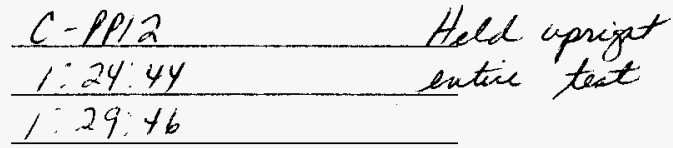

End Time:

1. 29.16

Test \pm 9

Test Specimen Number:

\begin{tabular}{|c|c|}
\hline$C-P P \|$ & at then twaned \\
\hline $2: 01: 15$ & onscide. add'l teme \\
\hline $2: 06: 30$ & $\begin{array}{l}\text { wes adked due to screb } \\
\text { alcuranp onseal area. }\end{array}$ \\
\hline
\end{tabular}

Tet $\$ 10$

Start Time: 2:06:30 wot added due to serut

End Time:

$\frac{6 \cdot p p / 0}{2: 39: 15}$

6 2. After the test is completed, towel dry the test specimens to remove any visible moisture on the external surfaces. Pay particular attention to the seal area to ensure all moisture is removed.

$\eta$ Remove the closure cap from each test specimen. Record the breakaway torque value below for each test specimen as appropriate.

\begin{tabular}{|c|c|c|c|}
\hline \multirow[b]{2}{*}{$110 \cdots$} & TEST SPECIMEN NUMBER & BREAKAWAY TOROUE VALUE & \multirow[b]{2}{*}{$=200+16$} \\
\hline & C-PP10 & stut (2) 90-bute ca Do & \\
\hline 4. & C-PP11 & sout (a) 90. moke 00 & \\
\hline $68-$ & C-PP12 & oter @90-putek65 & \\
\hline
\end{tabular}

84. Visually examine the interior of each test specimen for water. If needed, use a black light. Use the table below to note any moisture detection to the seal area, gasket, threads, and inside the test specimen. Use the table below to note any galling of the threads or seal. In addition, record any additional information as needed for documentation purposes.

\begin{tabular}{|c|c|c|c|c|c|c|}
\hline \multirow{2}{*}{$\begin{array}{c}\text { TEST SPECIMEN } \\
\text { NUMBER }\end{array}$} & \multicolumn{4}{|c|}{ MOISTURE } & \multicolumn{2}{|c|}{ GALIING } \\
\hline & SEAL & GASKET & THREADS & INSIDE & THREADS & SEAL \\
\hline C-PP10 & $y$ & NIA & $y$ & $y$ & $N^{\prime}$ & $N$ \\
\hline C-PP11 & $y$ & $N / A$ & $y$ & $y$ & $N$ & $N$ \\
\hline C-PP1 2 & $y$ & $N / A$ & $y$ & $N^{\prime}$ & $N$ & $N$ \\
\hline
\end{tabular}


HNF-3099 Rev. 0

HNE-2945 Rev. $\theta$

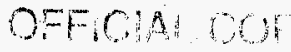

Tet $* 8(C \cdot P p / 2)$ - moisture roted at lid/body ententace, on

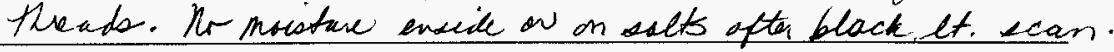

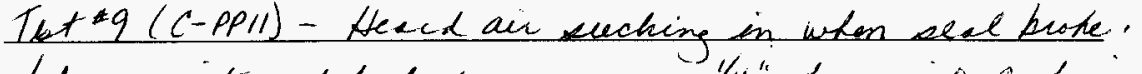

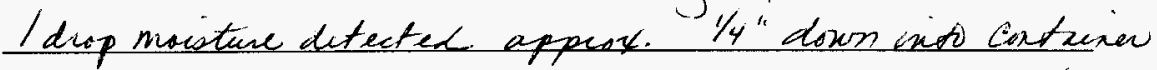
$($ own $)$
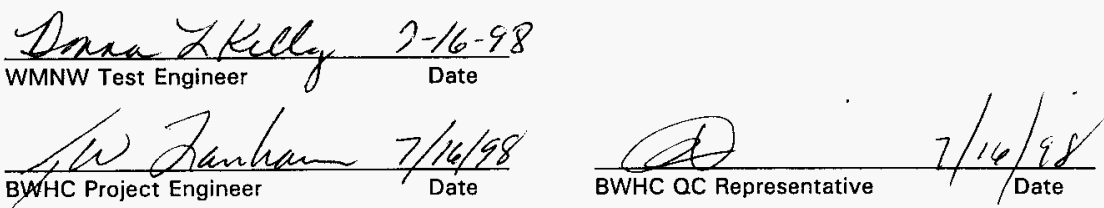

9 f. If galling is found, determine if it will affect the results of any additional testing.

10 6. If no water is found and additional testing will be performed, proceed to Section B.4.

1) If additional testing will not be performed, clean the test specimens to remove the flour and fluorescein mixture, and notify the BWHC project engineer for disposition of the test specimens.

\section{B.4 SCRUB TEST USING WATER DAMPENED RAGS}

$$
\begin{aligned}
& \text { Lec atached shuts for } \\
& \text { Leet \#1, \#12,\#13: } \\
& \text { This thot was nerdiped from onigenal. }
\end{aligned}
$$

\section{B.4.1 Preparation of Test Specimens}

A mixture of flour and fluorescein will be placed in each of the test units and the closure cap and seal wik be installed and torqued. Thi flour and fluorescein mixture will aid in the detection of any water that may leak into the teshspecimens. The detailed preparation procedures follow.

1. Ensure that each test specimen is clean and dry.

2. Determine if any galling found prior to conducting this test will affect the result of this test.

3. Thio flour and fluorescein mixture used in previous testing may be used if adequate. If notadequate, remove the old flour and fluorescein mixture and prepare three new mixtures of $1 / 4$ cup flour and $1 / 4$ tsp fluorescein. Place one prixture into each test
specimen.

NOTE: Caution should be used to ensure that none of the mixture bomes in contact with the test specimen outer surface or closure threads. 
$(7-16-98)$

HNF-3099 Rev. 0

Tet $H q$ (c-pp/I) Continued

I dup of moitere inside Cntainer wall; however the lid was pulled off quichly \& drop possibly fell from hid/thead area? No fenorsein detected in salt.

Text 10 (EPP10)

Mreatare detected at lid/body interface, theads, incide contriner wall Hessecin detected in salt auptrals $-($ appore 10).

OFFICIA SOPY

OFFICIA

A-65 
HNF-3099 Rev. 0 OFFICIAL COPY

let $\# 11, \# 12, \# / 3$

Heat / Norub hat Using Water Dampened Rage

Whe test epecimans have been cleared + polished prion to conducting this tat.

the pre-test requirements of section 6.1 (page 4) have buen met pios to thes teot.

Authorization is granted to assoncle the thet specimens and stout the teat, per 324 viojests Mgri Bwtte.

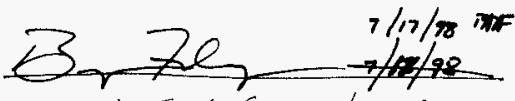

WMNal Tut Engr. / date

fac Renhar $2 / 1 / 98$

Bw the Prgeit ingr / date
\& $2 / 17 / 98$

BuHC QCR / date

Heat I dowb Tht Using Water Danpered Rage

$\operatorname{Let} * 11, \pm 12, * 13$

(1) He test specinens will have been clearce body* cap inteyare and be poliabed.

(2) Lest specimens hiel not include a gashet.

(3) Sest apecimens wies be filld with Crase sall cextil appeos. \$5-80\% full.

(4) Any galling hoted deening provious teating. shace be determined to not affect the resulds of additimal tieting.

(5) A rag will be sabuated with flow deld flevorocin and batei and cusung out entel domp. Damp way will be wasked over seal nea of t eat ent.

(6) Torque unill be 20 ft-th. A-66 
HNF-3099 Rev. 0 OFF,CIA C,OFY

Lat $\# / 1, \# / 2, * 3$

1. Hill test apecimens $35-80 \%$ full hith coase cuptal salt.

2. Heat trot units to appose $200^{\circ} \mathrm{C}\left(392^{\circ} \mathrm{F}\right)$ and remove from onen. (We Closure cap will hot - be heated.) Recond temperature in tabe belin.

3. Anstacl closure cap onto test specimen. Iree-ai Crot. hthen that unitreaches approx. $100^{\circ} \mathrm{C}\left(212^{\circ} \mathrm{F}\right)$ torque closure Cap to toftL. Necock the toique arench Calibration infornateri, test apecimen torgere values beton:

Lozaue wrend identification: $\quad 545-88-01-202$ hyt Calibuation due.

Roceptable range:

Lat equecinen $\#$ :

Iype of seal installed.

Heated Contaice tomp: (oven)

Widial forque value:

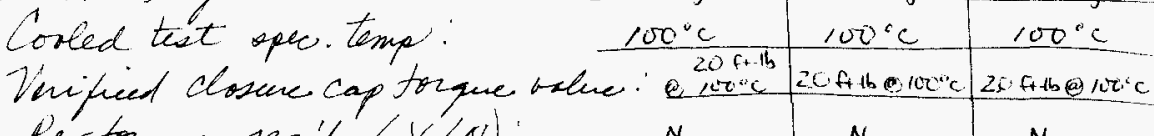

$2 / 27 / 99$

Re'-torque reg' $x$ ' $Y Y N)$.

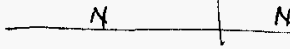

N

4. Ho to Section B.4.2. (ouigenat teat plan). Atep \#/.wiel now becme the \#5. Proceed with teoting

A-67 


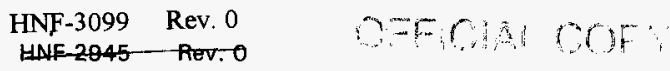

4. Install the closure cap and seal on each test specimen. Ensure that the identification marking of the lid mates with the identification marking of the body. On one test specimen use a BWHC fabricated seal; on the other two test specimens usse BWHC procured seals. Using the BWHC provided spanner, torque each closure cap to $25 \mathrm{ft}$-lbs. Record torque wrench calibration information, test specimen torque values, and type of seal below.

Torque Wrench Identification:

Next Calibration Due Date:

Acceptable Range:

\begin{tabular}{|c|c|c|}
\hline TEST SPEGIMEN NUMBER & $\begin{array}{c}\text { TYPE OF SEAL } \\
\text { INSTALLED }\end{array}$ & $\begin{array}{c}\text { CLOSURE CAP } \\
\text { TORQUE VALUE }\end{array}$ \\
\hline C-PP10 & & \\
\hline C-PP1 11 & & \\
\hline C-PP12 & & \\
\hline \multicolumn{2}{|c|}{} & \\
\hline
\end{tabular}

5. If needed, clean the external surface of the test specimens.

All test specimen preparation requirentents specified in Section B.4.1 are completed. Authorization is granted to start the test.

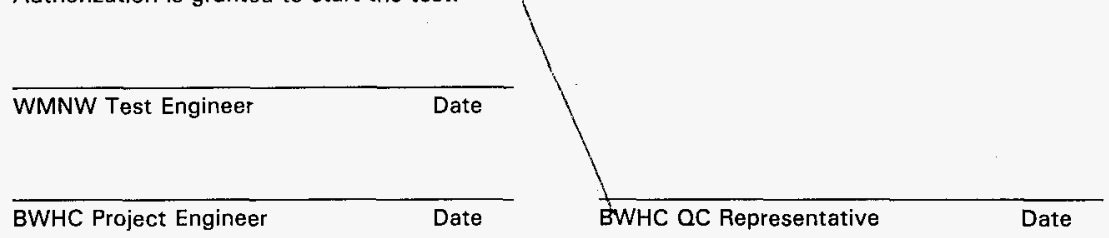

\section{B.4.2 Water Scrub Test Using Dampened Rag TEST NUMBER

$$
\text { Tote: Defa fo atached al uts naiber. }
$$

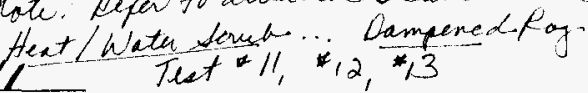

This test consists of subjecting each test specimen to a vigorous scrubbing using water dampened rags for a period of at least 5 minutes. After the test, the closure caps will be removed and the inside of each test specimen will be examined for water. The detailed procedure is as follows.

$$
\text { S. } x
$$

Place a test specimen in an appropriate holder. Dampen several rags with water and vigorously scrub the test specimen seal area for at least 5 minutes. Repeat the test for the other two test specimens. Record the following: 
HNF-3099 Rev. 0

HNF-2946 Rev. 0

Test Specimen Number:

Start Time:

$\frac{10}{14: 38: 00} \frac{14: 43.05}{-}$

Test Specimen Number:

$\frac{11}{14: 48: 30} \frac{14: 5.3: 3.5}{-14}$

Test Specimen Number:

$\frac{\frac{12}{15: 05: 25}}{15: 10: 30}$

6. 2. After the test is compieted, towel dry the test specimens to remove any visible moisture on the external surfaces. Pay particular attention to the seal area to ensure all moisture is removed.

7. 3. Remove the closure cap from each test specimen. Record the breakaway torque value below for each test specimen as appropriate.

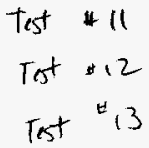

6. 4 .

\begin{tabular}{|c|c|c|}
\hline TEST SPECIMEN NUMBER & BREAKAWAY TORQUE VALUE & \\
\hline C-PP10 & Stated90,bruke@75fi-16 & $=15 \mu t$ \\
\hline C-PP.11 & Started 90, bruke of $74 f_{t}-16$ & $=16 \mathrm{ft}^{t}$ \\
\hline C-PP12 & Started 90 , broke 975 fi-16 & s pro \\
\hline
\end{tabular}

Visually examine the interior of each test specimen for water. If needed, use a black light. Use the table below to note any moisture detection to the seal area, gasket, threads, and inside the test specimen. Use the table below to note any galling of the threads and seal. In addition, record any additional information as needed for documentation purposes.

\begin{tabular}{|c|c|c|c|c|c|c|c|}
\hline \multirow[b]{3}{*}{ Test $* 11$} & \multirow{2}{*}{$\begin{array}{c}\text { TEST SPECIMEN } \\
\text { NUMBER }\end{array}$} & \multicolumn{4}{|c|}{ MOISTURE } & \multicolumn{2}{|c|}{ GALLING } \\
\hline & & SEAL & GASKET & THREADS & INSIDE & THREADS & SEAL \\
\hline & C-PP10 & $\mathrm{N}$ & $N / A$ & $N$ & $N$ & $N$ & $N / A$ \\
\hline Test 12 & C-PP11 & $N$ & $\mathrm{~N} / \mathrm{A}$ & $N$ & $N$ & N & $N / A$ \\
\hline Test ${ }^{*} 13$ & C-PP1 2 & $N$ & $N / A$ & $N$ & $N$ & $N$ & N/A \\
\hline
\end{tabular}


HNF-3099 Rev. 0

HNE-2945-ROV. $O$
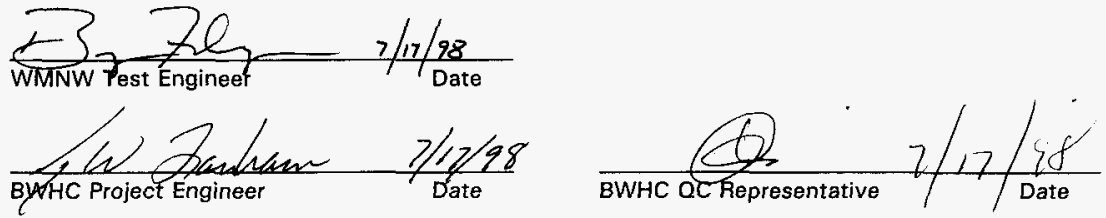

9. 5. If galling is found, determine if it will affect the results of any additional testing.

10. 6. If no water is found and additional testing will be performed, proceed to Appendix c.

11. 7. If additional testing will not be performed, clean the test specimens to remove the flour and fluorescein mixture, and notify the BWHC project engineer for disposition of the test specimens. 
HNF-3099 Rev. 0

HNF-2945 Rev. 0

\section{APPENDIX C \\ ADDITIONAL WATER IMMERSION TESTING \\ DUE TO TOROUE VALUE CHANGE}

\section{1 ADDITIONAL WATER IMMERSION TESTS}

If additional water immersion tests are desired by use of a torque value other than that idetified in Appendix B, Section B.1 of this procedure, proceed with the steps that follow.

\section{C.1.1 Preparation of Test Specimens}

A mixture of flour and fluorescein will be placed in each of the test units and the closure cap and seal will be installed and torqued. The flour and fluorescein mixture will aid in the detection of any water that may leak into the test specimens. The detailed preparation procedures are as follows.

1. Ensure that each test specimen is clean and dry.

2. Determine if any gualling found from previous tests will affect the result of this test.

3. The flour and fluorescein mixture used in previous tests may be used if adequate. If not adequate, remove the old flour and fluorescein mixture and prepare three new mixtures of $1 / 4$ cup flour and $1 / 4$ tsp fluorescein. Place one mixture into each test specimen.

NOTE: Caution should be used to ensure that none of the mixture comes in contact with the test specimen outer surface or closure threads.

4. Install the closure cap and seal on each test specimen. Ensure that the identification marking of the lid mates with the identification marking of the body. On one test specimen use a BWHC fabricated seal; on the other two test specimens use BWHC procured seals. Using the BWHC provided spanner, torque each closure cap to a pre-determined torque value, other than what has been used for previous testing. Record torque wrench calibration information, test specimen torque values, and type of seal below.

Torque Wrench Identification:

Next Calibration Due Date:

Acceptable Range:

\begin{tabular}{|c|c|c|}
\hline TEST SPECIMEN NUMBER & $\begin{array}{c}\text { TYPE OF SEAL } \\
\text { INSTALLED }\end{array}$ & $\begin{array}{c}\text { CLOSURE CAP } \\
\text { TORQUE VALUE }\end{array}$ \\
\hline C-PP10 & & \\
\hline C-PP11 & & \\
\hline C-PP12 & & \\
\hline
\end{tabular}


HNF-3099 Rev. 0

5. If needed, clean the external surface of the test specimens.

All test specimen preparation requirements specified in Section C.1.1 are completed. Authorization is granted to start the test.

WMNW Test Engineer Date

BWHC Project Engineer

Date

BWHC OC Representative

Date

\section{C.1.2 Water Immersion Test}

\section{TEST NUMBER}

The water immersion test consists of placing the test specimens in a pool of water to a depth of 8.1 feet for two periods of at least 5 minutes each. After the test, the closure caps will be removed and the inside of each test specimen will be examined for water. In addition, the threads and seals will be inspected for galling. The detailed procedure follows.

NOTE: The water temperature of the immersion pool and the test facility air temperature will be verified prior to the start of this test. If additional steps need to be taken during testing to ensure that a vacuum is not created within the Inner container, these steps will be documented within this test plan, and concurrence will be provided by the WMNW test engineer, BWHC project engineer (or designee), and the BWHC QC representative.

\begin{tabular}{|c|c|c|}
\hline TEST SPECIMEN NUMBER & $\begin{array}{c}\text { TEMPERATURE OF } \\
\text { POOL }\end{array}$ & $\begin{array}{c}\text { BLDG AIR } \\
\text { TEMPERATURE }\end{array}$ \\
\hline C-PP10 & & \\
\hline C-PP11 & & \\
\hline C-PP12 & & \\
\hline
\end{tabular}

1. Place the three test specimens in an appropriate holder and lower the specimens into the pool of water to a depth of 8.1 feet $(+0.5,-0 \mathrm{ft}$ ) (use 8 feet, 8 inches). The immersion depth is measured from the top of the water to the upper most surface of the test specimens. Hold the test specimens at the prescribed depth for at least 5 minutes. Remove the test specimens and repeat the immersion test for another period of at least 5 minutes. Record the following: 
HNF-3099 Rev, 0

HNF-2945-Rev. O

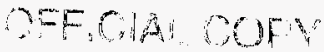

Period 1

Immersion Depth:

Start Time:

End Time:

\section{Period 2}

Immersion Depth:

Start Time:

End Time:

2. After the test is completed, towel dry the test specimens to remove any visible moisture on the external surfaces. Pay particular attention to the seal area to ensure all moisture is removed.

3. Remove the closure cap from each test specimen. Record the breakaway torque value below for each test specimen as appropriate.

\begin{tabular}{|c|c|}
\hline TEST SPECIMEN NUMBER & BREAKAWAY TORQUE VALUE \\
\hline C-PP10 & \\
\hline C-PP11 & \\
\hline C-PP12 & \\
\hline
\end{tabular}

4. Visually examine the interior of each test specimen for water. If needed, use a black light. Use the table below to note any moisture detection to the seal area, gasket, threads, and inside the test specimen. Use the table below to note any gualling of the threads or seal. In addition, record any additional information as needed for documentation purposes.

\begin{tabular}{|c|l|l|l|l|l|l|}
\hline \multirow{2}{*}{$\begin{array}{c}\text { TEST SPECIMEN } \\
\text { NUMBER }\end{array}$} & \multicolumn{5}{|c|}{ MOISTURE } & \multicolumn{2}{c|}{ GALLING } \\
\cline { 2 - 7 } & SEAL & GASKET & THREADS & INSIDE & THREADS & SEAL \\
\hline C-PP10 & & & & & & \\
\hline C-PP11 & & & & & & \\
\hline C-PP12 & & & & & & \\
\hline
\end{tabular}


HNF-3099 Rev. 0

HNF-2945 Bev $\theta$

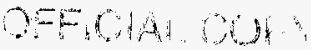

WMNW Test Engineer Date

BWHC Project Engineer Date

BWHC QC Representative Date

5. If gualling is found, determine if it will affect the results of any additional testing.

6. If no water is found and additional testing will be performed at a higher torque value, use additional test sheets provided in Appendic $C$ as needed.

7. If additional testing will not be performed, clean the test specimens to remove the flour and fluoresceine mixture, and notify the BWHC project engineer for disposition of the test specimens. 
CUSTODIAN/ADDRESS

BOYD JAI

$\mathrm{N} 1-86$

INSTRUMENT

IORQUE WRENCH

SNAP-ON TORQOMETER

$0-100$ FT-LBS.

SENDER

T HEIDCAMP 6-9047

INSTRUMENT SPECIFICATIONS

$+/-4 \%$ RDG: NO ACCURACY REQUIREMENT FROM $0 \%$ THRU $20 \%$ OF

FUIL, SCALE

Standard (s) used in calibration traceable to National Institute

of Standazds and Techrology or nationally recognized standazds.

EXPIRATION DATE EXPIRATION

$\frac{0}{02}-79-06-006-\frac{56-98}{10-7-90}$

REMARKS

CLOCKWISE ONLY

PROCEDURE NUMBER

WHC-8-TORQUE-WRENCH REV. 0

TEST POINT

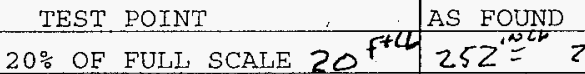

$40 \%$ OF FULI SCALE 40

$60 \%$ OF FULL SCALE 60

$80 \%$ OF EITIT, SCAIT, 80

$100 \%$ OF EULL SCALEIDO
STANDARDS CODE NUMBER

$545-88-01-202$

SERIAL NUTBER

6064

\begin{tabular}{l|l}
15 & $4713 B$ \\
\hline COMMEATS
\end{tabular} $\begin{aligned} & \text { PROPERTY NUMBER } \\ & N / A \\ & \text { SERVICE DEPARTMENTT } \\ & 8\end{aligned} \mid$

[4: RATIO?

EXPIRATION DATE

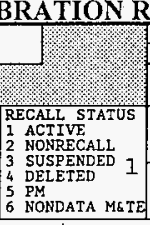

TEE

MODIFY

\begin{tabular}{l|l} 
REF & \\
414538
\end{tabular}

WI 8600 WCODE WORK ORDER

\begin{tabular}{l|l}
$W 18600$ & $B 1160$
\end{tabular}

RECALL CYCLE TOLERANCE HISTORY

$\frac{360}{\text { DATE RECEIVED }}$

980225

RUSH? CO ID

I I I I

TOLERANCE

AS RSGEIVED 1) \begin{tabular}{l|l|l|l}
$\mathrm{NO}$ & 5 & $\mathrm{WE}$ & $3 \mathrm{NA}$ \\
4
\end{tabular}

NO CHARGE:

TRAINING HOURS

ACTUAL CAL HRS

OTHER HOURS

ENG/ADMIN HOURS

BILLED:

STD CAL HOURS

REPAIR HOURS

MATERIALS

TOTAL CHARGE =

( $\$ 165 \times$ SUM OF HOURS ) + MATERIALS DATE CALIBRATED DATE DUE

\begin{tabular}{l|l}
$z-z>-98$ & $2-27-89$
\end{tabular}

AMBIENT TEMPERATURE $=19.7^{\circ} \mathrm{C}$

TOLERANCE

SEE ABOVE $N / A$

SEE ABOVE $+1.6^{\text {frCl }}$

SEE ABOVE " $7.4^{\circ} "$

SEF ABOVF $\cdots>? * 4$

SEE ABOVE - $4.0^{*}$

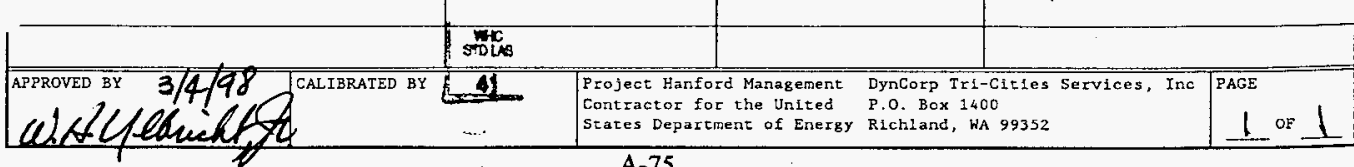


HNF-3099 Rev. 0

This page intentionally left blank. 


\begin{tabular}{|c|c|c|c|c|c|}
\hline \multicolumn{6}{|c|}{ DISTRIBUTION SHEET } \\
\hline \multirow{2}{*}{$\begin{array}{l}\text { To } \\
\text { Distribution }\end{array}$} & \multirow{2}{*}{\multicolumn{3}{|c|}{$\begin{array}{l}\text { From } \\
\text { Packaging Engineering }\end{array}$}} & \multicolumn{2}{|l|}{ Page 1 of 1} \\
\hline & & & & \multicolumn{2}{|c|}{ Date $07 / 23 / 98$} \\
\hline \multicolumn{4}{|l|}{ Project Title/Work Order } & \multicolumn{2}{|c|}{ EDT No. 622929} \\
\hline \multicolumn{4}{|c|}{$\begin{array}{l}\text { Test Report for Cesium Powder and Pellets Inner Container } \\
\text { Decontamination Method Determination Test (HNF-3099) }\end{array}$} & \multicolumn{2}{|l|}{ ECN No. NA } \\
\hline Name & MSIN & $\begin{array}{l}\text { Text } \\
\text { With All } \\
\text { Attach. }\end{array}$ & Text Only & $\begin{array}{l}\text { Attach./ } \\
\text { Appendix } \\
\text { Only }\end{array}$ & $\begin{array}{l}\text { EDT/ECN } \\
\text { Only }\end{array}$ \\
\hline $\begin{array}{l}\text { P. C. Ferrell } \\
\text { J. G. Field } \\
\text { C. J. Geiss } \\
\text { C. R. Hoover } \\
\text { D. L. Kelly } \\
\text { G. W. Lanham } \\
\text { M. M. Pereira } \\
\text { HNF-3099 File } \\
\text { Work Control (D. Kelly) } \\
\text { Document Processing Center }\end{array}$ & $\begin{array}{l}H 1-15 \\
H 1-15 \\
\text { L1-06 } \\
\text { H1-15 } \\
\text { HI-15 } \\
\text { L1-06 } \\
\text { S6-81 } \\
\text { H1-15 } \\
\text { H1-15 } \\
\text { A3-94 }\end{array}$ & $\begin{array}{l}x \\
x \\
x \\
X \\
x \\
X \\
x \\
X \\
X \\
X\end{array}$ & & & \\
\hline D. H. Sandoz & L1-06 & $x$ & & & \\
\hline
\end{tabular}

